Division of Geological \& Geophysical Surveys

PRELIMINARY INTERPRETIVE REPORT 2009-6a

\title{
SURFICIAL GEOLOGY OF ALASKA HIGHWAY CORRIDOR, ROBERTSON RIVER TO TETLIN JUNCTION, ALASKA
}

by

Richard D. Reger, Trent D. Hubbard, and Gary A. Carver

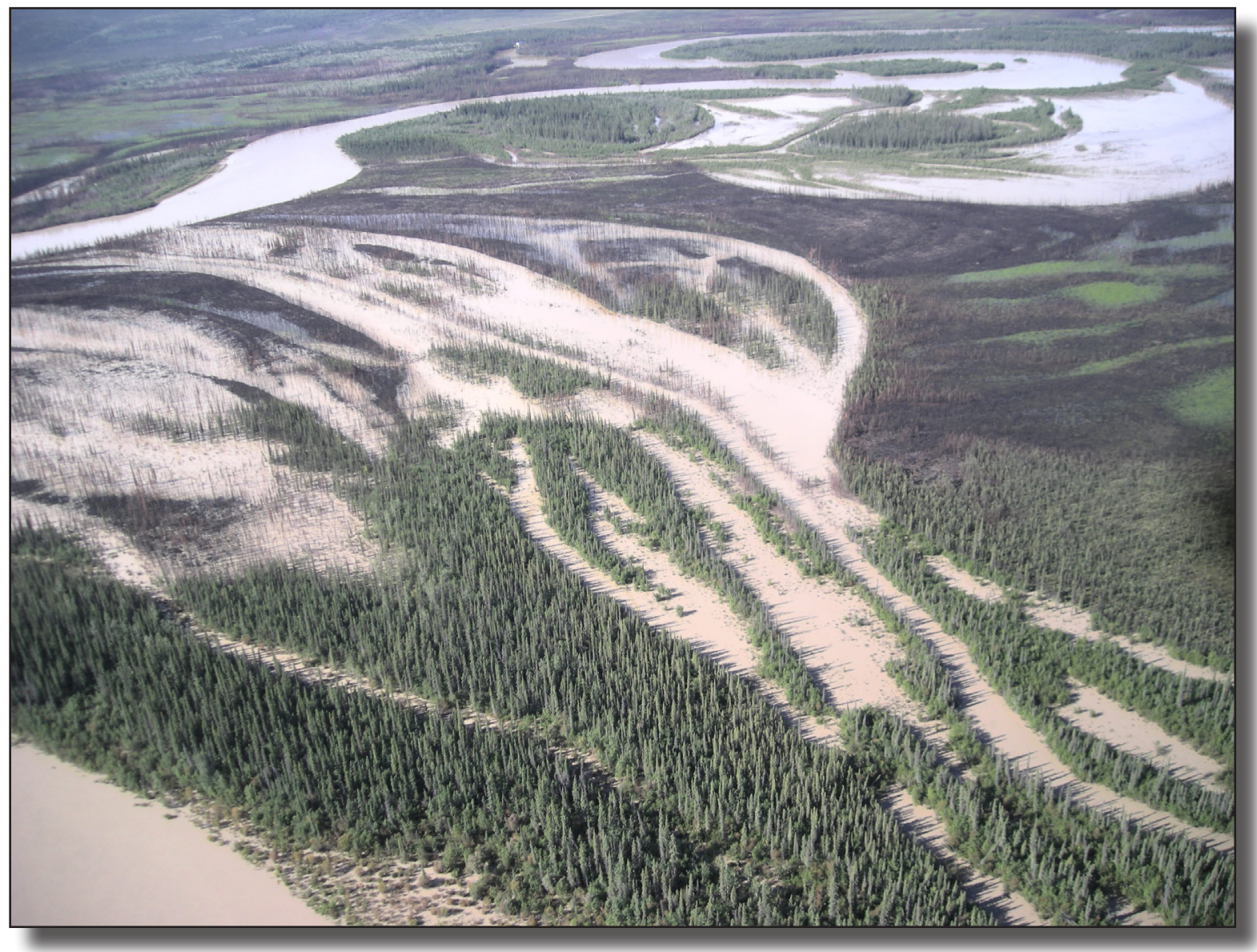

Oblique view of flooding along the Tanana River northeast of Tanacross. Note meander scrolls clearly visible in the flooded area. Photograph taken 07/26/2010 by T. D. Hubbard.

\section{December 2011}

Released by

STATE OF ALASKA

DEPARTMENT OF NATURAL RESOURCES

Division of Geological \& Geophysical Surveys

3354 College Rd., Fairbanks, Alaska 99709-3707

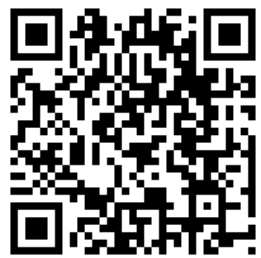





\section{CONTENTS}

Introduction

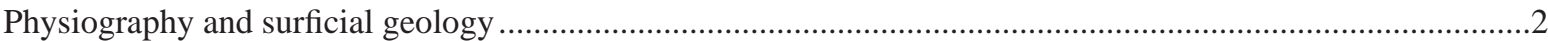

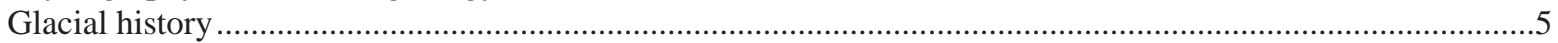

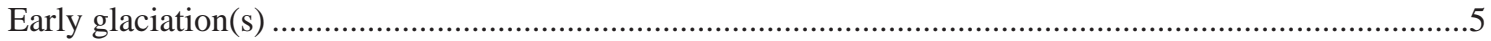

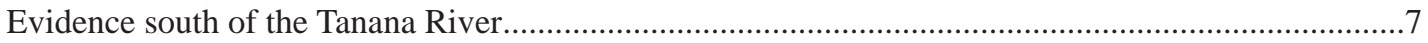

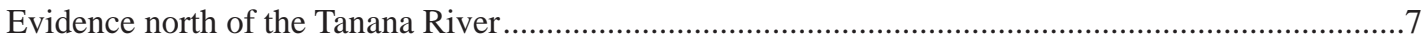

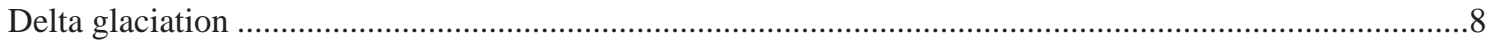

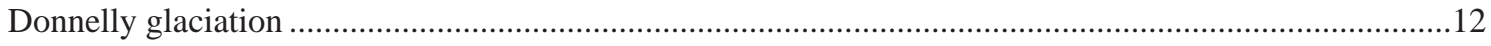

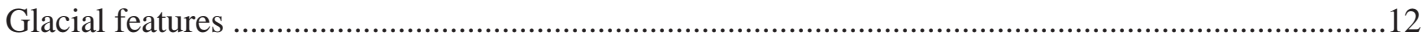

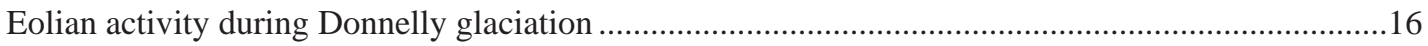

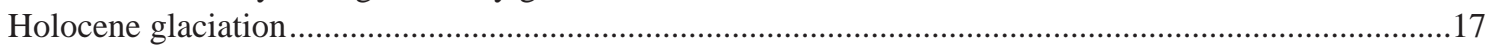

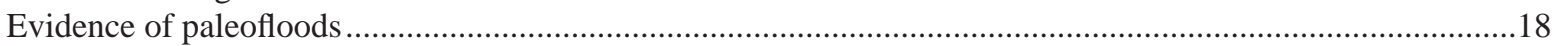

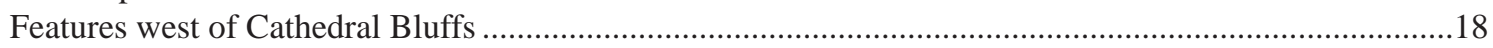

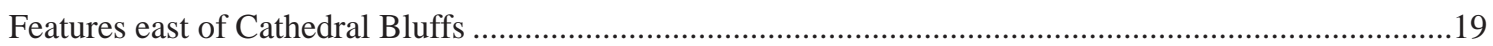

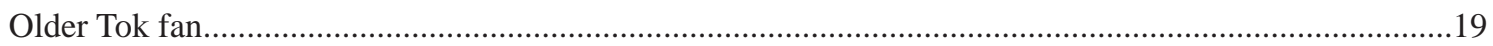

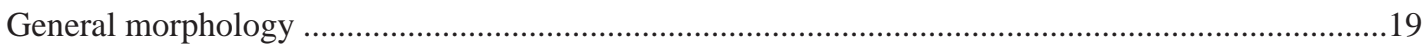

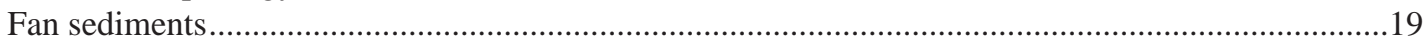

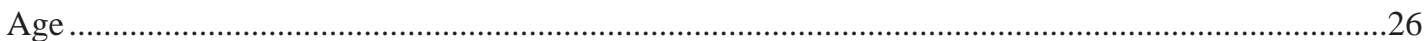

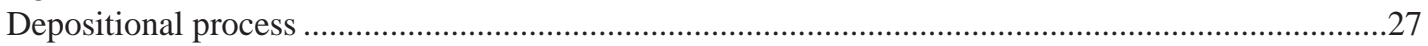

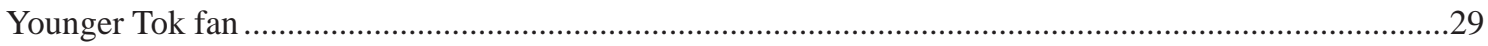

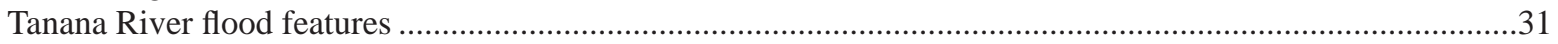

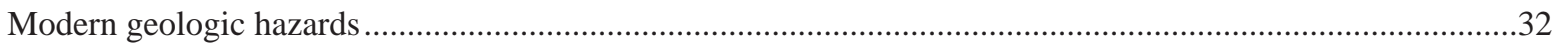

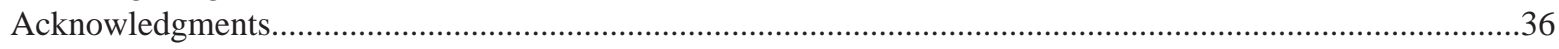

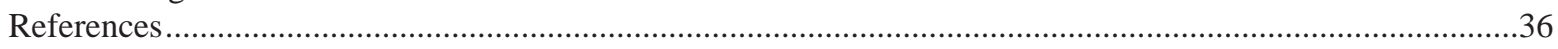

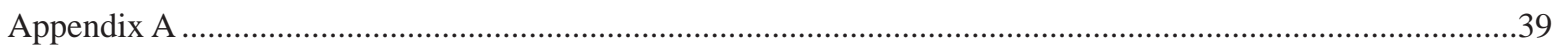

Figure 1. Location map of study area in Tanacross Quadrangle, Alaska.............................................. 1

2. Map showing expansion-fan and slackwater-basin complex in Fish Lake-Wolf Lake area, north-central Tanacross B-5 Quadrangle

3. Interpretation diagram of borings drilled in and near the footprint of proposed bridge \#505 over the Tanana River at MP 1303.3 Alaska Highway in the southeast Tanacross B-4 Quadrangle......

4. Photo showing aerial view northeast of the clearwater lake impounded behind parabolic sand dunes in a recent burn near the Taylor Highway north of Tetlin Junction in the east-central

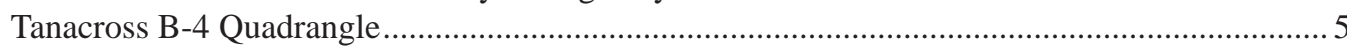

5. Profile A-A' from summit of Mt. Neuberger southeast across Tok River valley, Tanacross A-5 and B-5 quadrangles, showing probable Tertiary surface and tentative cross-glacier profiles

6. Photo showing northeast view of subrounded to rounded granitic corestones and weathered granitic bedrock in a quarry near the mouth of Porcupine Creek, east-central Tanacross B-4 Quadrangle.

7. Soil profile (SP-6) in Robertson River terminal moraine of Delta glaciation, southwestern Tanacross B-6 Quadrangle.

8. Soil profile (SP-7) in proximal outwash of Delta age in east-central Tanacross B-6 Quadrangle.

9. Air photo showing estimated maximum height of glacial ice during Delta glaciation and failures in granitic bedrock, Tower Bluffs, Tanacross B-6 and C-6 quadrangles ...................... 11

10. Air photo showing comparison of surface forms of Robertson River moraines of Delta and Donnelly ages in Mt. Hayes C-1 Quadrangle.

11. Diagram showing section (SP-8) exposed in crest of highway cut through Donnelly terminal moraine of Robertson River glacier in northwestern Tanacross B-6 Quadrangle ..... 
12. Photo showing a 0.2-in-thick (5-mm-thick) layer of caliche-cemented coarse sand coats lower surfaces of this noncalcareous metamorphic cobble from ablation till in Donnelly moraine exposed in highway cut in northwestern Tanacross B-6 Quadrangle.

13. Model for blockage of Tanana River at Tower Bluffs by Robertson River glacier during Donnelly glaciation....

14. Section exposed in test pit (SP-9) in rounded crest of Holocene end moraine at head of west

fork of Sheep Creek in northwestern Tanacross B-6 Quadrangle.

15. Section exposed in test pit (SP-10) in expansion fan of Donnelly age in northwestern

Tanacross B-6 Quadrangle.

16. Soil profile (SP-11) exposed in west wall of M.S. 62-2-009-5 in western Tok fan, in westcentral Tanacross B-5 Quadrangle .................................................................................... 20

17. Comparison of (A) sengpiel airborne resistivity section 12930 and (B) interpreted geologic cross-section in Wolf Lake area, central Tanacross B-5 Quadrangle

18. Photo showing extraordinarily large in-situ greenstone boulder outlined for clarity in clastand matrix-supported gravels and sample locations in south wall of M.S. 62-2-005-2, northeastern Tok fan, Tanacross B-4 Quadrangle.

19. Photo showing cross section through large channel filling in west wall of M.S. 62-2-005-2, northeastern Tok fan, Tanacross B-4 Quadrangle.....

20. Photo showing locations of samples in exposed gravels and sands in west wall of

M.S. 62-2-005-2, northeastern Tok fan, Tanacross B-4 Quadrangle

21. Diagram showing shape classes of extraordinarily large boulders in northeastern Tok fan.........26

22. Map showing course of outburst floods from Mentasta Pass to Tok fan during Donnelly glaciation relative to locations of large boulders in northeastern Tok fan .................................... 27

23. Diagram showing abundances of gravel, sand, and fine-fraction components in samples of gravel and sand beds in south and west walls of M.S. 62-2-005-2 ............................................ 28

24. Diagram showing relation of stress to strain in Newtonian and non-Newtonian fluids ............... 30

25. Section (SP-12) exposed in gravel pit in younger part of Tok fan in southwestern Tanacross B-4 Quadrangle..... 27

6. Photo showing cross-bedded sand and sandy pebble-gravel fill in a shallow channel on the younger Tok fan east of the Tok River, central Tanacross B-4 Quadrangle .

Stratigraphic section (SP-13) in loess and eolian sand blanket over grüssified granitic bedrock on north bank of Tanana River at centerline of proposed new Alaska Highway bridge, southeastern Tanacross B-4 Quadrangle...

28. Air photo showing features indicating groundwater emergence in vicinity of Tanacross Airfield, west-central Tanacross B-5 Quadrangle.

29. Photo showing curved stems of alder shrub tipped and broken during deposition of natural levee along unnamed small stream above the Alaska Highway in east-central Tanacross B-6 Quadrangle.

30. Photo showing view up floodplain of Yerrick Creek toward the Alaska Highway bridge, east-central Tanacross B-6 Quadrangle, showing numerous large boulders deposited by torrential flooding

\section{TABLES}

Table 1. Summary of radiocarbon dates associated with late Quaternary deposits in the Alaska Highway corridor, Tanacross Quadrangle ....

2. Dimensions of extraordinarily large boulders in northeastern Tok fan and calculations for shape plot.

3. Grain size distributions of gravels and sands exposed in west wall and south wall of M.S. 62-2-005-2,Tanacross B-4 Quadrangle

4. Comparison of properties and deposits of water floods, hyperconcentrated flows, and debris flows 


\section{SHEETS}

(in envelope)

Sheet 1. Surficial-geologic map, Alaska Highway Corridor, part of the Tanacross C-6 Quadrangle, Alaska

2. Surficial-geologic map, Alaska Highway Corridor, part of the Tanacross B-6 Quadrangle, Alaska

3. Surficial-geologic map, Alaska Highway Corridor, parts of the Tanacross A-5 and B-5 quadrangles, Alaska

4. Surficial-geologic map, Alaska Highway Corridor, parts of the Tanacross A-4 and B-4 quadrangles, Alaska 



\section{SURFICIAL GEOLOGY OF ALASKA HIGHWAY CORRIDOR, ROBERTSON RIVER TO TETLIN JUNCTION, ALASKA}

by

Richard D. Reger ${ }^{1}$, Trent D. Hubbard ${ }^{2}$, and Gary A. Carver ${ }^{3,4}$

\section{INTRODUCTION}

During 2008, the Alaska Division of Geological \& Geophysical Surveys continued a program of reconnaissance mapping of surficial geology begun in 2006 in the proposed natural-gas pipeline corridor through the upper Tanana River valley (Combellick, 2006; Solie and Burns, 2006, 2007). Mapping during 2008 in the Tanacross Quadrangle linked with mapping of surficial geology completed in the Big Delta and Mt. Hayes quadrangles in 2007 and extended across the Tanacross Quadrangle to the vicinity of Tetlin Junction (fig. 1) (Reger and others, 2008a; Reger and Solie, 2008a and b).

Surficial geology was initially mapped in this second corridor segment by interpreting $\sim 1: 65,000$-scale, falsecolor, infrared aerial photographs taken in July 1978, August 1980, and July 1983, and plotting unit boundaries

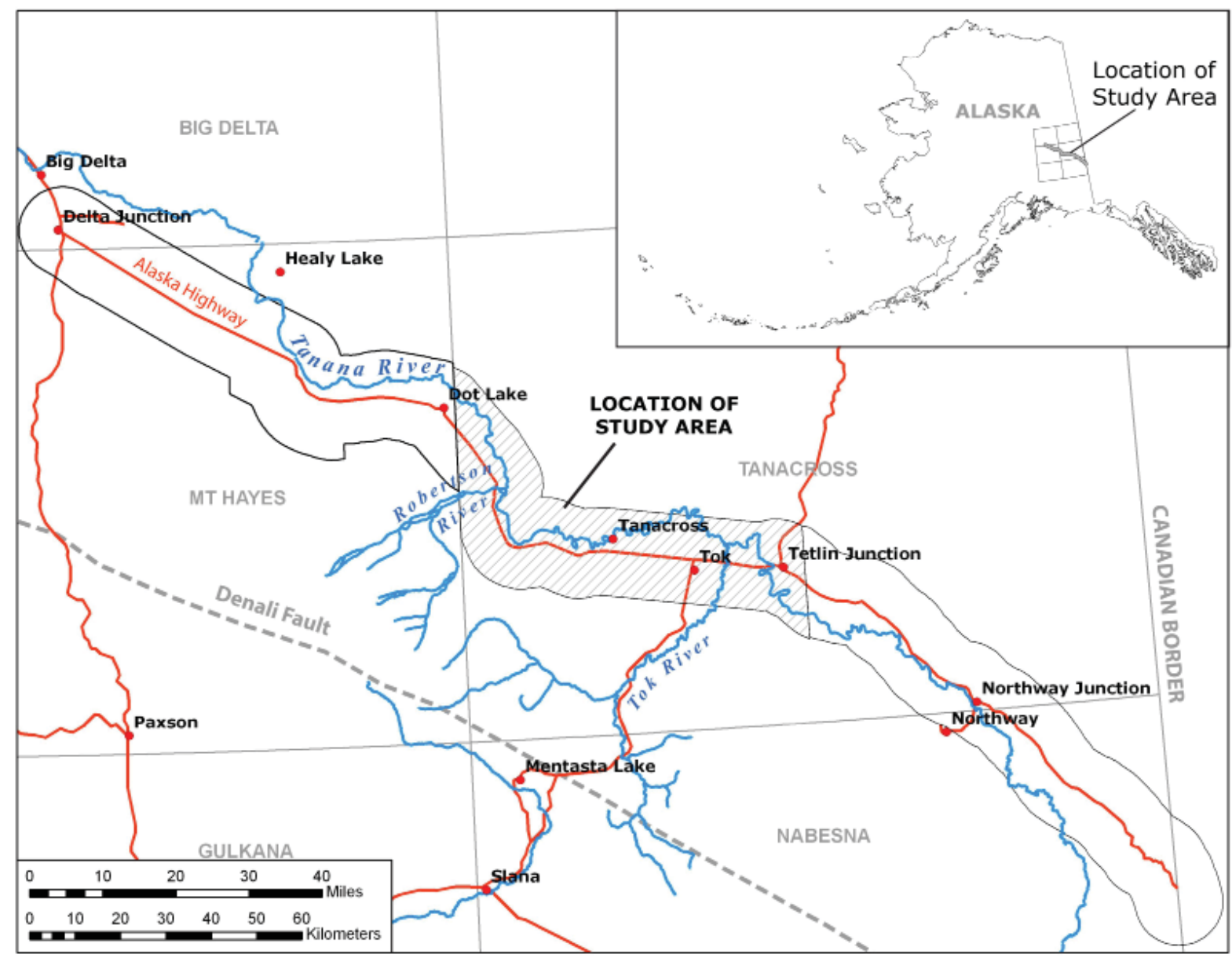

Figure 1. Location map of study area in Tanacross Quadrangle, Alaska.

${ }^{1}$ Reger's Geologic Consulting; P.O. Box 3326; Soldotna, Alaska 99669

${ }^{2}$ Alaska Division of Geological \& Geophysical Surveys, 3354 College Rd., Fairbanks, Alaska 99709-3707

${ }^{3}$ Humboldt State University, Emeritus

${ }^{4}$ Carver Geologic Inc., PO Box 52, Kodiak, Alasak 99615 
on acetate overlays. Special attention was given to identifying geologic processes and conditions that potentially might negatively impact future development in the corridor, including faults, permafrost, mass-movement features, and areas prone to flooding and liquefaction. Potential sources of construction materials were also identified. Information from previous geologic reports was incorporated. Verification of photo mapping was completed during the 2008 field season, when map units were described, soil pits were hand dug, and samples were collected for analyses. Descriptions of soil pits in this report use standard soil-horizon nomenclature (Soil Survey Staff, 1975). Soil colors are described using the Munsell color chart. Following orthorectification of the aerial photographs and associated acetate overlays, unit boundaries were digitized onscreen into ArcGIS and the surficial-geologic maps were prepared (sheets 1-4).

\section{PHYSIOGRAPHY AND SURFICIAL GEOLOGY}

Through most of the reach across the Tanacross Quadrangle, the Tanana River hugs the southern margin of the Yukon-Tanana Upland (sheets 1-4). This stream-dissected upland of rounded ridges and hills has a maximum relief of $\sim 2,235 \mathrm{ft}(\sim 681 \mathrm{~m})$; low, scattered tors stand above ridge crests and upper side slopes. Drainages in the southern upland are well integrated, and tributaries to the Tanana River are generally very short and steep compared to north-flowing drainages. Sandy Holocene loess thinly and discontinuously blankets upper ridges and thickens close to the Tanana River. In this area, the upper sections of Holocene loess typically display a thin, white tephra, the northern lobe of the White River Ash, which is $\sim 1,890 \mathrm{RC}$ yr old (Schaefer, 2002; Carrara, 2006). Eolian sand and reworked eolian sand locally blanket low ridges and stream terraces close to the Tanana River. Fills of loess mixed with retransported loess and sand in upland valleys are organic, frozen, and ice rich (Reger and Solie, 2008a).

The Tanana River abruptly changes character at its junction with the Robertson River, which flushes large volumes of coarse granular sediment into the Tanana River (sheets 1 and 2). Downstream from the junction, channels of the Tanana River are complexly braided and anastomosing, and river bars are light toned, indicating that they are composed primarily of permeable sand and gravel. Near the mouth of Sheep Creek, the Tanana River valley narrows significantly where the southern Yukon-Tanana Upland approaches to within $3 \mathrm{~km}$ of the northern flank of the eastern Alaska Range. Through this reach to the eastern limit of the study area, the Tanana River follows a meandering course, and point bars and river bars are dark toned, indicating that they are composed of saturated fine sand and silt. Observations after the magnitude 7.9 (M7.9) earthquake of November 3, 2002, indicate that fine-grained floodplain deposits in this reach are highly susceptible to liquefaction (Harp and others, 2003).

In the $\sim 31-\mathrm{km}-$ long reach from Robertson River to the vicinity of Moon Lake, the Tanana River is pinned against bedrock hills of the southern Yukon-Tanana Upland by outwash fans and colluvial-fluvial fans emanating from valleys in the eastern Alaska Range (Carrara, 2004a) (sheet 2).

From Moon Lake $\sim 77 \mathrm{~km}$ upstream to the mouth of the Tok River, where the river is again pinned against the nose of a bedrock ridge, the Tanana River flows around the toe of the broad Tok fan through a meander belt that is up to $\sim 5.6 \mathrm{~km}$ wide (sheets 2-4) (Carrara, 2004b, 2006). Along the northern limit of the meander belt, expansion fans deposited by Holocene floods impound a series of slackwater basins and associated clearwater lakes, including Fish and Wolf lakes and Lake Mansfield, against the southern Yukon-Tanana Upland (fig. 2). The fine-grained sediments in these slackwater basins are overlain by or interfinger with lowland loess, eolian sand, retransported loess and sand, and peat. Permafrost is continuous, $<0.9 \mathrm{~m}$ deep, and ice rich, and several basins contain opensystem pingos (Holmes and others, 1968). The crests of bedrock knobs surrounded by alluvium stand $\sim 60$ to $182+$ $\mathrm{m}$ above the floodplain and the outer Tok fan (sheets 3 and 4 ).

In the $18.5 \mathrm{~km}$ reach from the mouth of the Tok River to the crossing of the Tanana River by the Alaska Highway east of Tok, the Tanana River remains close to the southern limit of the Yukon-Tanana Upland. Upstream from the Alaska Highway bridge to the eastern limit of the study area, the Tanana River meanders across a 3.7- to 9.3-kmwide swampy lowland between the southern Yukon-Tanana Upland to the northeast and the stream-dissected upland surface of the northeastern Alaska Range to the southwest (sheet 4). Interpretation of borings drilled for the proposed new bridge over the Tanana River (Fitch, 2008) indicates that the lowland is underlain by $\sim 30$ to $41 \mathrm{~m}$ of fluvial sand and gravel deposited by the meandering Tanana River (fig. 3). This dominantly fine-grained alluvium, which is highly prone to liquefaction and is discontinuously frozen beneath the inactive floodplain, overlies $\sim 23$ $\mathrm{m}$ of glaciofluvial gravel with minor sand. At 1,550 ft $(470 \mathrm{~m})$ elevation, a 1.5- to 3.6-m-thick layer of lacustrine silt and clay is present at a depth of 15 to $19.7 \mathrm{~m}$, probably contributing to the poorly drained nature of the lowland. Physiographic relations indicate that the lowland developed as a consequence of the Holocene growth of the eastern part of the Tok fan when the Tanana River became restricted to a narrow opening between the fan and the bedrock ridge to the north (sheet 4). If fan growth was rapid enough, a lake could have developed upstream of the 


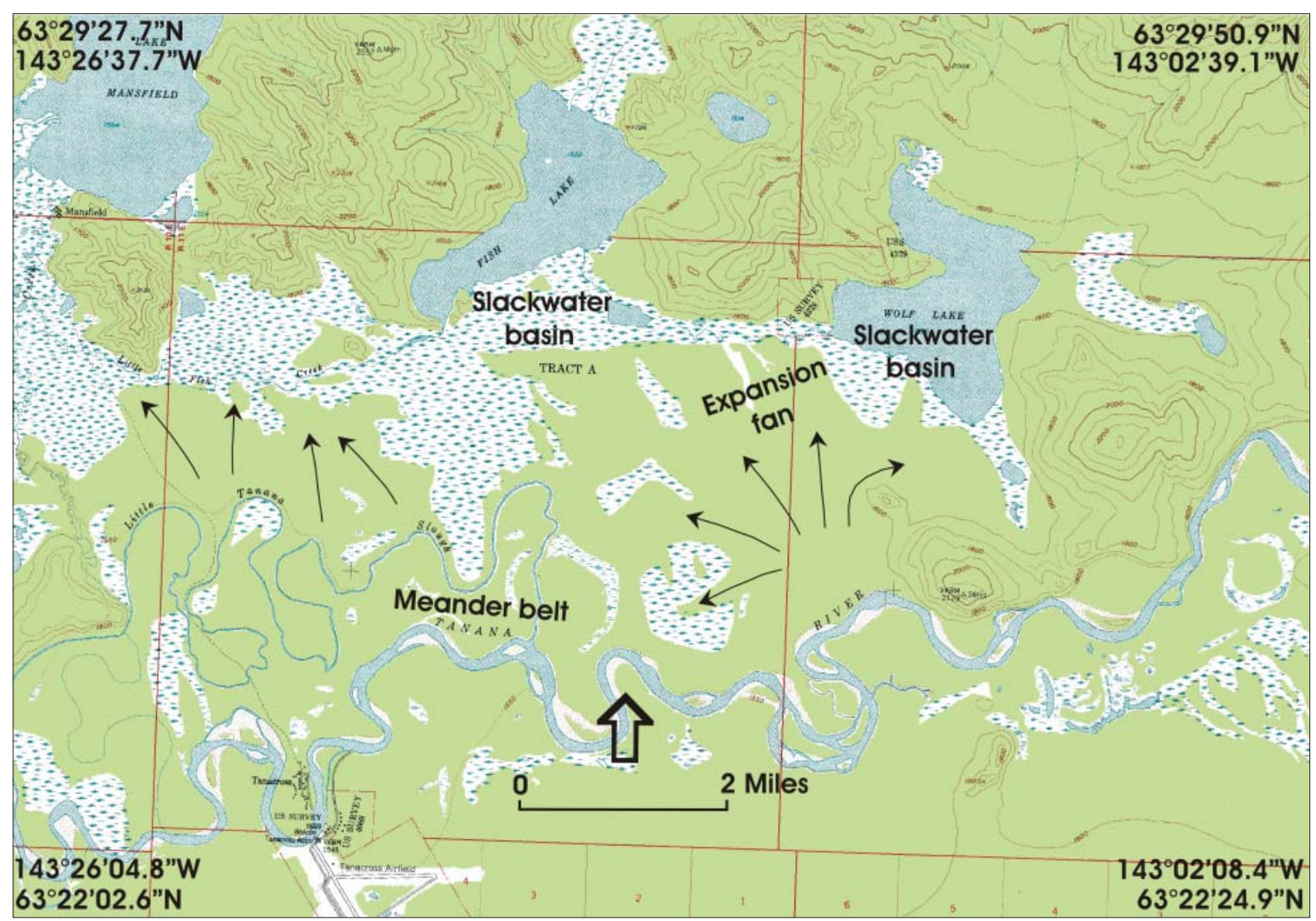

Figure 2. Map showing expansion-fan and slackwater-basin complex in Fish Lake-Wolf Lake area, north central Tanacross B-5 Quadrangle. Arrows indicate general directions of overbank flows.

restriction. Outburst floods down the Tok River valley may have contributed to lake formation, but we recognize no evidence of these inundations upstream of the Tok fan in the upper Tanana River valley.

Across the Tanana River northeast of the Tok fan is the Tetlin Junction dune field (sheet 4). The position of this dune field relative to the Tok fan indicates that the eolian sands there were deposited by strong katabatic winds sweeping northeastward out of the Tok River valley across the Tok fan. The orientations of parabolic sand dunes west of the Taylor Highway (fig. 4) indicate that winds have most recently blown across the dune field from the Tok fan toward the northeast, although dune orientations east of the Taylor Highway record winds blowing from the south and southeast there (Carrara, 2006). The 60-m-deep canyon of middle Porcupine Creek demonstrates that the dune field in the Tetlin Junction-Porcupine Creek area is very thick. Numerous rills with convex cross profiles in the eolian-sand blanket west of lower Porcupine Creek indicate that the sand is thick there also.

The rugged eastern Alaska Range rises to $\sim, 100 \mathrm{ft}(\sim 2,150 \mathrm{~m})$ elevation south of the Tanana River valley. Mountain valleys and jagged, sharp, intervening bedrock ridges result from alpine glacial erosion. Periglacial weathering of metamorphic lithologies east of the Robertson River has extensively modified bedrock slopes compared to glaciated alpine terrain west of the Robertson River, where the bedrock is predominantly granitic. Mountain slopes are littered with the products of gravity-driven processes, including talus fans and aprons, rock glaciers, and slope-failure deposits (sheets 2 and 3). East of the Robertson River, colluvial fans and aprons fairly extensively bury lateral moraines of the last major glaciation, imparting a misleading old appearance to the glacial features.

Southwest of the Tanacross Airfield (sheet 2), the northwest-trending, linear mountain front is probably the result of faulting, which remains active and is a continuation of neotectonism to the west along the northern flank of the Alaska Range (Carver and others, 2008a and b, 2010; Bemis and Wallace, 2007). Activity along the rangefront fault has tectonically deformed the coarse piedmont-apron diamictons to produce the conspicuous, arcuate, discontinuous ridge (growth anticlines) along the toe of the piedmont slope (Carver and others, 2010).

A dissected upland surface of possible Tertiary age is preserved just south of the corridor between the Tok River valley and the $6,747 \mathrm{ft}(2,045 \mathrm{~m})$ summit of Mt. Neuberger. This surface was mapped as felsenmeer rubble 
by Carrara (2004a), indicating that the landform is littered with residual coarse, angular products of frost-rived bedrock. However, except on the uppermost slopes of Mt. Neuberger, dry exposures on ridges and slopes are vegetated with discontinuous Dryas mats; moist slopes are well vegetated by a variety of moisture-tolerant alpine plants and exhibit landforms produced by gelifluction. Bedrock tors along ridge crests and on upper side slopes demonstrate that differential stripping by periglacial slope processes has removed at least $5 \mathrm{~m}$ of the metamorphic bedrock. The steeper, western portion of this surface could reflect $\sim 152 \mathrm{~m}$ of original relief on the former surface, or could result from faster uplift of the Alaska Range to the west. Toward the southeast, the slope of this surface is fairly uniform down to $\sim 3,500 \mathrm{ft}(\sim 1,065 \mathrm{~m})$ elevation, which could be the highest level reached by glaciation in the Tok River valley (fig. 5).

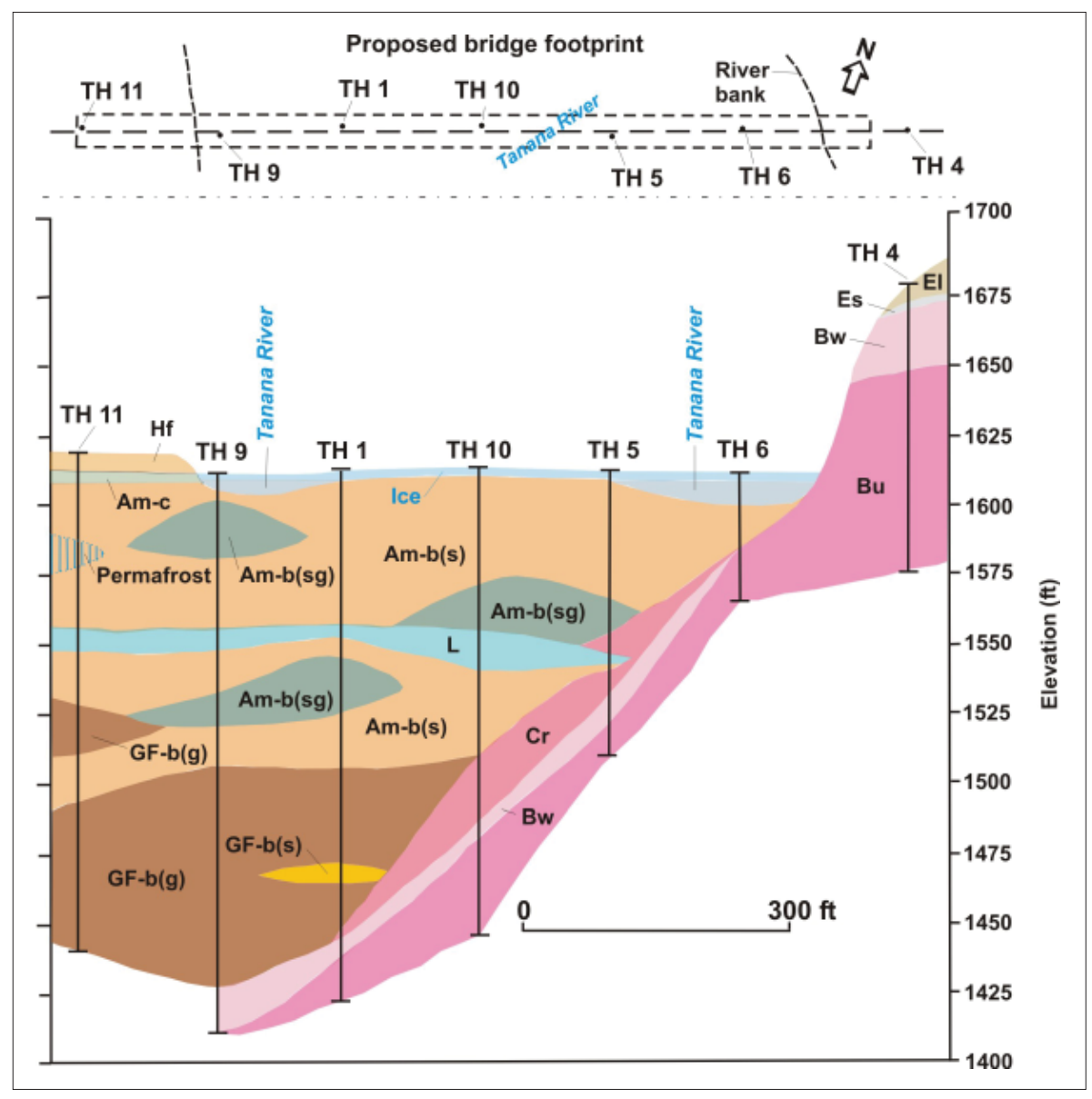

Figure 3. Interpretation diagram of borings drilled in and near the footprint of proposed bridge \#505 over the Tanana River at milepost 1303.3 Alaska Highway in the southeastern Tanacross B-4 Quadrangle (Fitch, 2008). Symbols: Am-c = fine-grained cover sediments in inactive floodplain of meandering Tanana River; $A m-b(s)=$ bedload sands deposited by meandering Tanana River; Am-b(sg) = bedload sands with minor pebble gravel deposited by meandering Tanana River; $B u=$ unweathered to slightly weathered granitic bedrock; $B w=$ weathered granitic bedrock; $\mathrm{Cr}=$ granitic colluvium (gravels mixed with grüs and fragments of weathered granite); $E l=$ loess; Es = eolian sand; $G F-b(g)=$ bedload gravels of outwash alluvium; $G F b(s)=$ bedload sands of outwash alluvium; Hf = highway fill; $L=$ lacustrine clays, silty clays, and clayey silts. Vertical exaggeration $=3.2$. 


\section{GLACIAL HISTORY}

Remnants of at least four glaciations of Pleistocene age are recognized in or near the corridor in the Tanacross Quadrangle (sheets 1-4). Correlations with glacial features in the corridor in the Big Delta and Mt. Hayes quadrangles are based on similar relative extents, similar appearances, soil properties, and landform interrelations (Reger and Péwé, 2002; Reger and others, 2008a). The most useful soil properties for distinguishing between different glacial deposits in the field are solum depth; color of B horizon; frequency, color, and thickness of clay skins; intensity of soil alteration; and presence of cryogenic features (Tarnocai and others, 1985).

\section{EARLY GLACIATION(S)}

Evidence of one or more pre-late Pleistocene glaciation(s) is scattered and difficult to verify or correlate because of post-depositional changes. In the eastern Alaska Range, these events were lumped into one glacial event, termed the Darling Creek glaciation, of pre-Illinoian age by Péwé (1975), but they could correlate with several early glaciations identified by Thorson (1986) farther west along the northern flank of the Alaska Range and in the Yukon Territory to the east by Hughes (1989). Evidence for the ages of the early glaciation(s), Delta glaciation, and Donnelly glaciation is discussed at length in Reger and others (2008a). More recently, cosmogenic-exposure evidence in the type area of the Delta and Donnelly glaciations near the western end of the corridor demonstrates that the inner of two Delta end moraines is OIS 4 (early Wisconsinan) in age and the Donnelly terminal moraine is OIS 2 (late Wisconsinan) in age (Matmon and others, 2010).

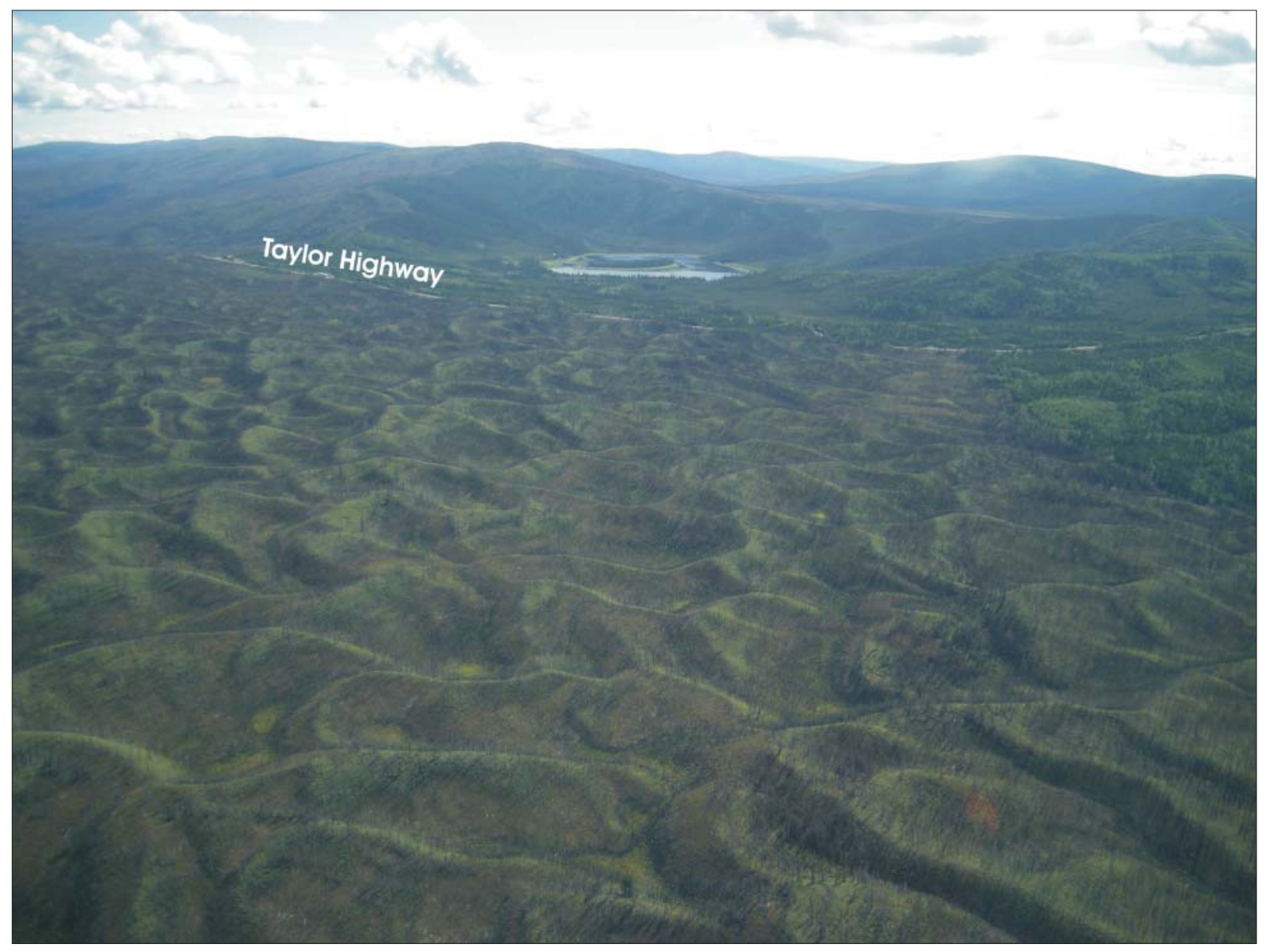

Figure 4. Photo showing aerial view northeast of the clearwater lake impounded behind parabolic sand dunes in a recent burn near the Taylor Highway north of Tetlin Junction in the east-central Tanacross B 4 Quadrangle. Photograph taken 06/12/2007 by R.D. Reger. 


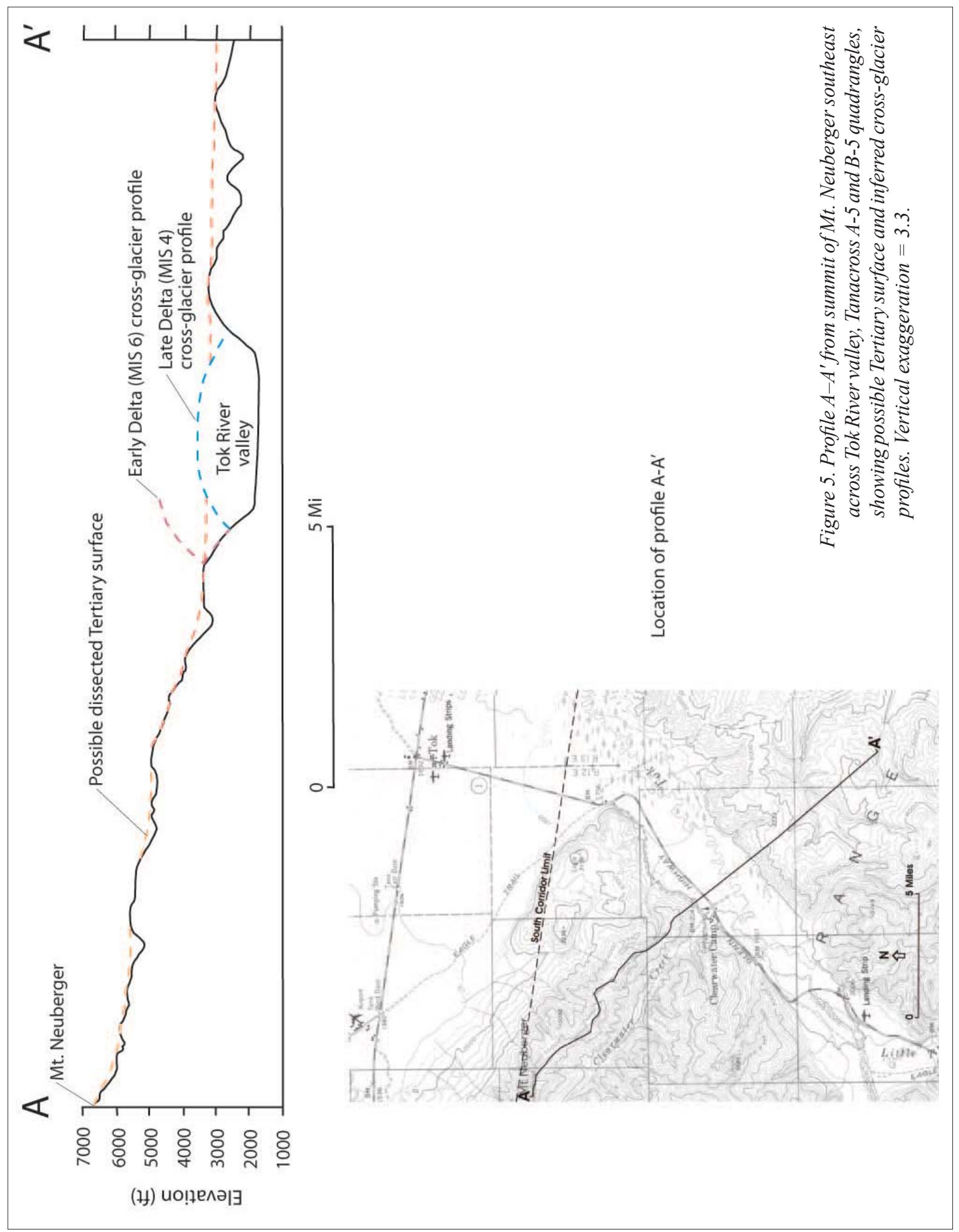




\section{Evidence south of Tanana River}

Duk-Rodkin and others (2002) mapped Pliocene-early Pleistocene erratics on the upland northwest of the Tok River valley, and Duk-Rodkin and others (2004) described a site at $\sim 3,015 \mathrm{ft}(\sim 920 \mathrm{~m})$ elevation west of the Tok River, where they claimed the dissected upland surface is littered with a veneer of glacial erratics, and bears a thin (20-cm-thick) luvisol profile that they interpret to possibly be early to middle Pleistocene in age. The paleomagnetic sample collected on this surface has a normal paleomagnetic signature, which they attribute to the Bruhnes Epoch because the erratics are fairly well preserved.

At two localities on the upland surface northwest of the Tok River valley, Foster (1970) mapped patches of gravel, which she described as round to angular clasts of white quartz, quartzite, polished black chert, and gneiss. She believed that these gravels were derived from the Alaska Range and could be Tertiary in age. Paul Carrara (04/22/2008, written commun.) revisited this surface and observed a lag of white quartz pebbles. Later, Carrara $(06 / 04 / 2008$, written commun.) suggested that the most convincing evidence of glaciation of that upland surface includes the gravel patches mapped by Foster and the presence of likely meltwater channels cut into the upland near the mouth of the Tok River valley.

We revisited the two gravel localities mapped by Foster (1970) on the upland surface and found a thin, discontinuous lag composed mainly of angular to subrounded pebbles of white quartz among clasts of micaceous and chloritic schist and quartzite, and gneiss. Maximum pebble diameter was $16 \mathrm{~cm}$. Rare subrounded pebbles of volcanic rock types and black chert were also present. No round clasts were observed, and no granitic clasts were found, although granitic bedrock is exposed nearby. We found no evidence of glaciation, such as boulder or cobble erratics of clearly exotic lithologies, at either upland site and concluded that the lag was likely produced by residual weathering of the local metamorphic bedrock and colluvial reworking of high-level, possibly Tertiary stream gravels.

\section{Evidence north of the Tanana River}

Duk-Rodkin and others $(2002,2004)$ described fairly well preserved granitic, volcanic, and chert clasts that they identified as erratics at the mouth of Porcupine Creek at $\sim 2,210 \mathrm{ft}(\sim 670 \mathrm{~m})$ elevation northeast of Tok at the margin of the southern Yukon-Tanana Upland (sheet 2). They attributed these clasts to a pre-middle Pleistocene glaciation from the eastern Alaska Range that advanced down the Tok River valley and filled the Tok-Tanacross basin to at least $\sim 2,210 \mathrm{ft}(\sim 670 \mathrm{~m})$ elevation. This occurrence is very unusual for the Tanana River valley, where several workers have searched in vain for evidence of glaciation north of the Tanana River. Carrara (06/04/2008, written commun.) visited two sites identified by Florence Weber, one of the coauthors of the 2004 Duk-Rodkin and others paper, as sites visited by their field party. There, he found only spheroidally weathered boulders derived from the local granitic bedrock. We visited the sites identified by Carrara and support his interpretation that the round, granitic boulders are corestones produced by weathering of the granitic bedrock (fig. 6).

Figure 6. Photo showing view northeast of subrounded to rounded granitic corestones and weathered granitic bedrock in a quarry near the mouth of Porcupine Creek, east-central Tanacross B-4 Quadrangle. Photograph taken 07/23/2008 by R.D. Reger.

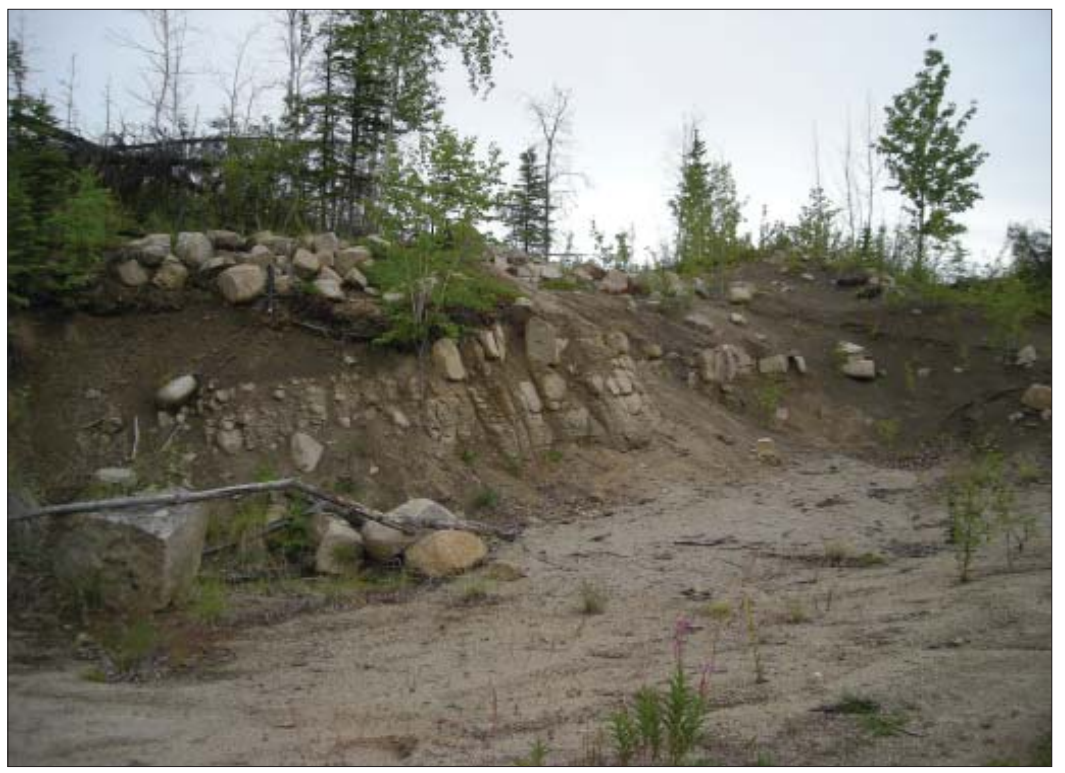


However, we did recover clasts of Alaska Range lithologies north of the Tanana River in the vicinity of the locality cited by Duk-Rodkin and others (2004). At $\sim 1,800 \mathrm{ft}(545 \mathrm{~m})$ elevation on the old Tok road just west of the mouth of Porcupine Creek, a pebble gravel containing exotic clasts overlies a grüs slopewash deposit. The largest clast exposed in the roadbed was a small $(26 \mathrm{~cm})$, subrounded, greenstone boulder. Subangular to subrounded pebbles and small cobbles in the gravel include other Alaska Range lithologies, such as fine-grained amygdaloidal volcanics and granitics, as well as a $10 \mathrm{~cm}$ subrounded, vesicular volcanic clast that is clearly derived from the Wrangell Mountains. These rock types indicate that the gravels were transported through the Alaska Range and down the Tok River valley to the south.

Initially, we thought that the well-preserved state of these exotic clasts and their position opposite the mouth of the Tok River valley near several exceptionally large boulders (sheet 4, localities A-C) could indicate that the clasts were deposited by massive floods that burst down the Tok River valley during a past glaciation (Reger and Hubbard, 2009; Hubbard and Reger, 2010). The highest of these clasts, up to $\sim 36 \mathrm{~m}$ above the basin floor, could represent the highest levels reached by run-up pulses during colossal outburst floods in the Tok-Tanacross basin. However, we were unable to find flood gravels between the old Tok road and the Tanana River floodplain as one would expect if floods deposited the gravels, and we found no gravels along the old Tok road closer to the Alaska Highway or in the vicinity of the new bridge crossing of the Tanana River along the Alaska Highway. This lack of flood confirmation raises the possibility that the flood gravels in the bed of the old Tok road just west of the mouth of Porcupine Creek were hauled to that site from gravel sources on the old Tok fan and used as road bedding. Thus, the presence of erratics north of the Tanana River cannot now be confirmed.

\section{DELTA GLACIATION}

Features assigned to the Delta glaciation were probably deposited during early (OIS 6) and late (OIS 4) phases (Reger and others, 2008a). We cannot separate deposits of these phases in the Tanacross Quadrangle, therefore we group fairly well preserved glacial features formed prior to the last major glaciation into the Delta glaciation.

Although some of their moraines and outwash fans were later eroded or buried during the Donnelly glaciation, almost all of the valleys along the north flank of the eastern Alaska Range contained glaciers during the Delta glaciation (sheets 1-3). The largest compound glacier in Robertson River valley existed in this area; the glacier in the Yerrick Creek valley was the second largest.

A remnant of the terminal moraine of the Robertson River glacial advance of Delta age is preserved between the massive terminal moraine of Donnelly age and the bedrock hill surrounding Jan Lake to the north (sheet 1). A soil test pit (SP-6) dug into this feature exposed 10 to $22 \mathrm{~cm}$ of micaceous silty loess overlying till (silt and fine to coarse sand with some clay and scattered to numerous subrounded, polymictic pebbles and cobbles up to $24 \mathrm{~cm}$ in diameter) (fig. 7). The loess contains a B horizon, which is mottled by frost action to red (10R4/6) (estimated 75-80 percent), weak red (10YR4/4) (estimated 10-15 percent), and reddish brown (2.5YR4/4) (estimated $<10$ percent). The red colors are thought to result from oxidation during repeated wildfires, and probably do not reflect the antiquity of the soil profile. The underlying $2 \mathrm{Bw}$ zone, which is yellowish brown (10YR5/6) and 14 to $24 \mathrm{~cm}$ thick, is developed in till. Silt caps on clasts in this horizon are thin $(<1 \mathrm{~mm})$ and bottom surfaces are clean. In the 2Cox horizon, a platy structure that developed parallel to the ground surface may be the result of freezing and thawing of the ground or may be evidence of downslope displacement of the near-surface till. Matrix color in this horizon is light olive brown (2.5Y5/6), and silt caps are up to $3 \mathrm{~mm}$ thick.

A soil test pit (SP-7) was excavated into proximal outwash close to the boundary with till of Delta age in a complex fan built by Yerrick Creek (sheet 2). The pit is at the transition from till to coarse outwash. The surface layers of silty loess of Donnelly age are $\sim 33 \mathrm{~cm}$ thick and have a dark brown to brown (10YR4/3 to 10YR5/3) matrix color in the B horizon (fig. 8). The $2 \mathrm{Bw}$ horizon is developed in medium to coarse proximal outwash sand with scattered subrounded to rounded, polymictic pebbles, and the matrix color is dark yellowish brown (10YR4/6). An estimated 10 to 15 percent of the clasts have partially disintegrated. In the underlying 2Cox horizon in pebble-cobble gravel with some medium-to-coarse sand and scattered small boulders, the matrix color is dark brown (10YR3/3), and an estimated 30 percent of the clasts have partially disintegrated.

Inspections of soil profiles on landforms of Delta age indicate that these post-Delta profiles are thicker than post-Donnelly profiles developed on landforms of Donnelly age, but may have B horizons that are roughly equivalent in thickness and color to B horizons in post-Donnelly profiles, particularly where the B horizon is limited to the loess cover (Reger and others, 2008a). However, downward displacement of silts and clays has progressed to a degree in post-Delta profiles that silt-clay caps are thicker on clasts, and silts and clays locally encase pebbles and cobbles in 'hardpan' (Bt) horizons. 


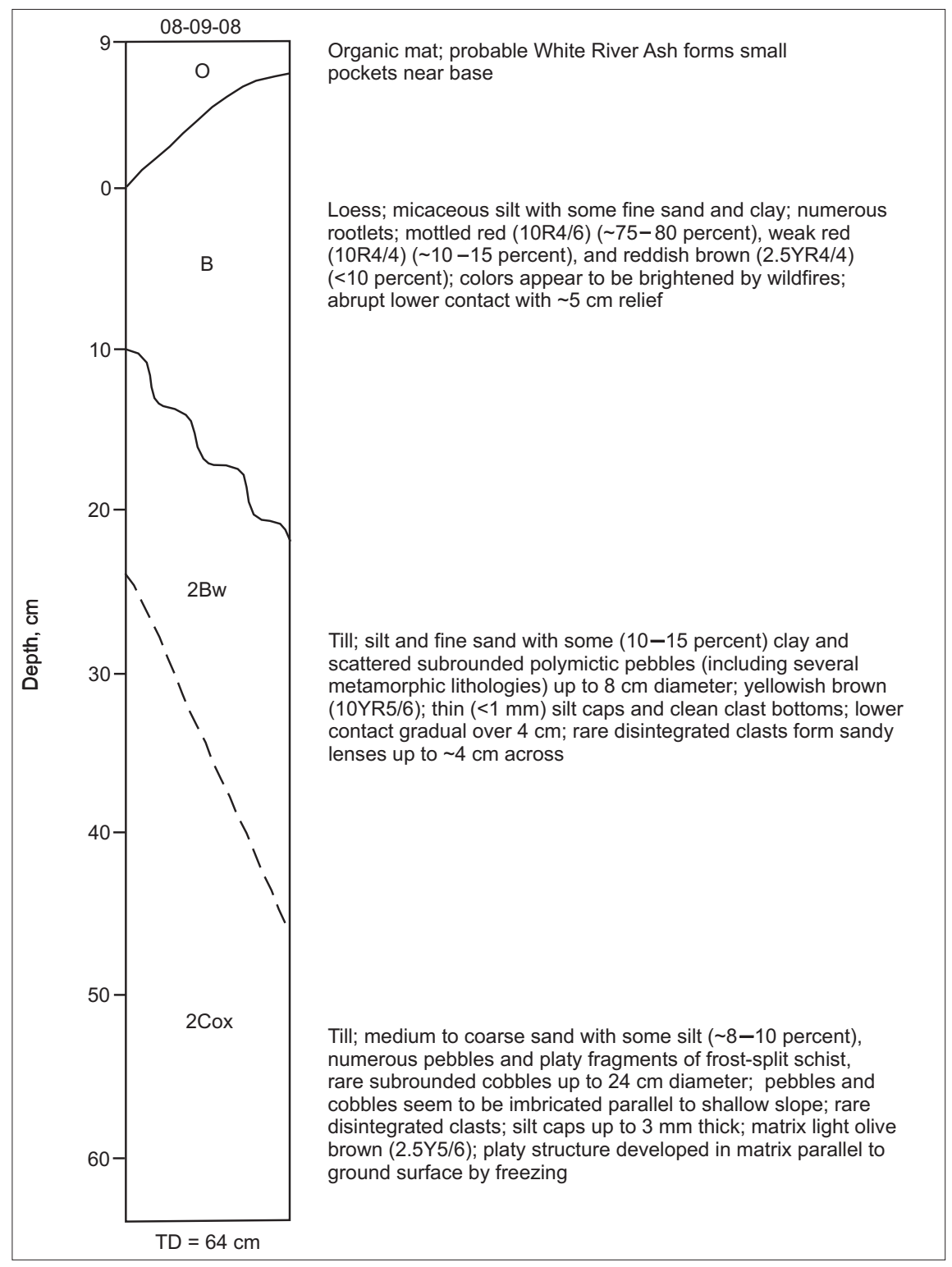

Figure 7. Soil profile (SP-6) in Robertson River terminal moraine of Delta glaciation, southwestern Tanacross B-6 Quadrangle. Elevation 1,700 $f t(518 \mathrm{~m})$.

The presence of faceted spurs as high as $\sim 2,200 \mathrm{ft}$ ( $\sim 670 \mathrm{~m}$ ) elevation on the $\sim 395$ - to $\sim 455$-m-high face of Tower Bluffs indicates that the Robertson River glacier could have been as thick as $\sim 167 \mathrm{~m}$ against that rock wall during the Delta glaciation and temporarily blocked the upper Tanana River (fig. 9). Certainly, the presence of a lateral moraine of Delta age outside and above the terminal moraine of Donnelly age south of the Robertson River and a terminal moraine remnant of Delta age north of the Robertson River (sheet 2) indicates that Delta ice was thicker and more extensive there than ice of the last major glaciation. During a ground survey along the crest of Tower Bluffs we found no glacial erratics but at $\sim 2,900 \mathrm{ft}(\sim 880 \mathrm{~m})$ elevation we encountered gneissic bedrock tors 1.2 to $1.8 \mathrm{~m}$ tall, indicating that glacial ice had not reached this elevation for a considerable time, if ever. The steepness, height, and instability of the face of Tower Bluffs precluded any attempt to search for erratics there.

One approach to estimating the height of the former glacier dam at Tower Bluffs is based on the principle that glacier-dam flotation and release of impounded meltwaters typically occurs when the impounded-water level rises to $\sim 90$ percent of the ice thickness, although there is considerable variation in this ratio (Tweed and Russell, 1999, $\mathrm{p}$. 92). The lowest pass over which rising waters dammed behind the Robertson River glacier could have overflowed is $9.7 \mathrm{~km}$ north-northeast of Tower Bluffs at an elevation of $\sim 1,950 \mathrm{ft}(\sim 591 \mathrm{~m})$. The large lowland basin east of this threshold is pocked with numerous thaw lakes, which indicate the presence of ice-rich fine-grained deposits, 
such as lake sediments (Wallace, 1948). However, during several aerial surveys down the valley west of this pass, we did not find evidence that impounded meltwaters overtopped that bedrock threshold. Therefore, the level of meltwaters impounded upstream of the Robertson River glacier during the Delta glaciation appears not to have risen to a level $\sim 136 \mathrm{~m}$ above the base of Tower Bluffs (at $\sim 1,500 \mathrm{ft}[\sim 455 \mathrm{~m}]$ elevation), implying that the ice at Tower Bluffs was probably $<\sim 152 \mathrm{~m}$ thick during the Delta glaciation. Several failures in the granitic bedrock of Tower Bluffs today could have resulted from removal of lateral support (debuttressing) when the ice withdrew from the cliff (Cossart and others, 2008) or from undercutting of Tower Bluffs by subsequent river activity, or both.

Remnants of Delta-age lateral moraines, terminal-moraine lobes, and associated outwash fans are related to alpine valleys of the eastern Alaska Range between the Robertson River valley and the Tok-Tanacross basin (sheets 2 and 3 ).

Outwash fans of Delta age extend downslope between dissected, arcuate ridges of tectonically deformed colluvial-fluvial deposits (Qcft) along the mountain front southwest of the Tanacross Airfield (Carver and others, 2010). Previously, those discontinuous ridges were mapped as moraines of Delta age by Foster (1970) and as bedrock by Carrara (2004b).

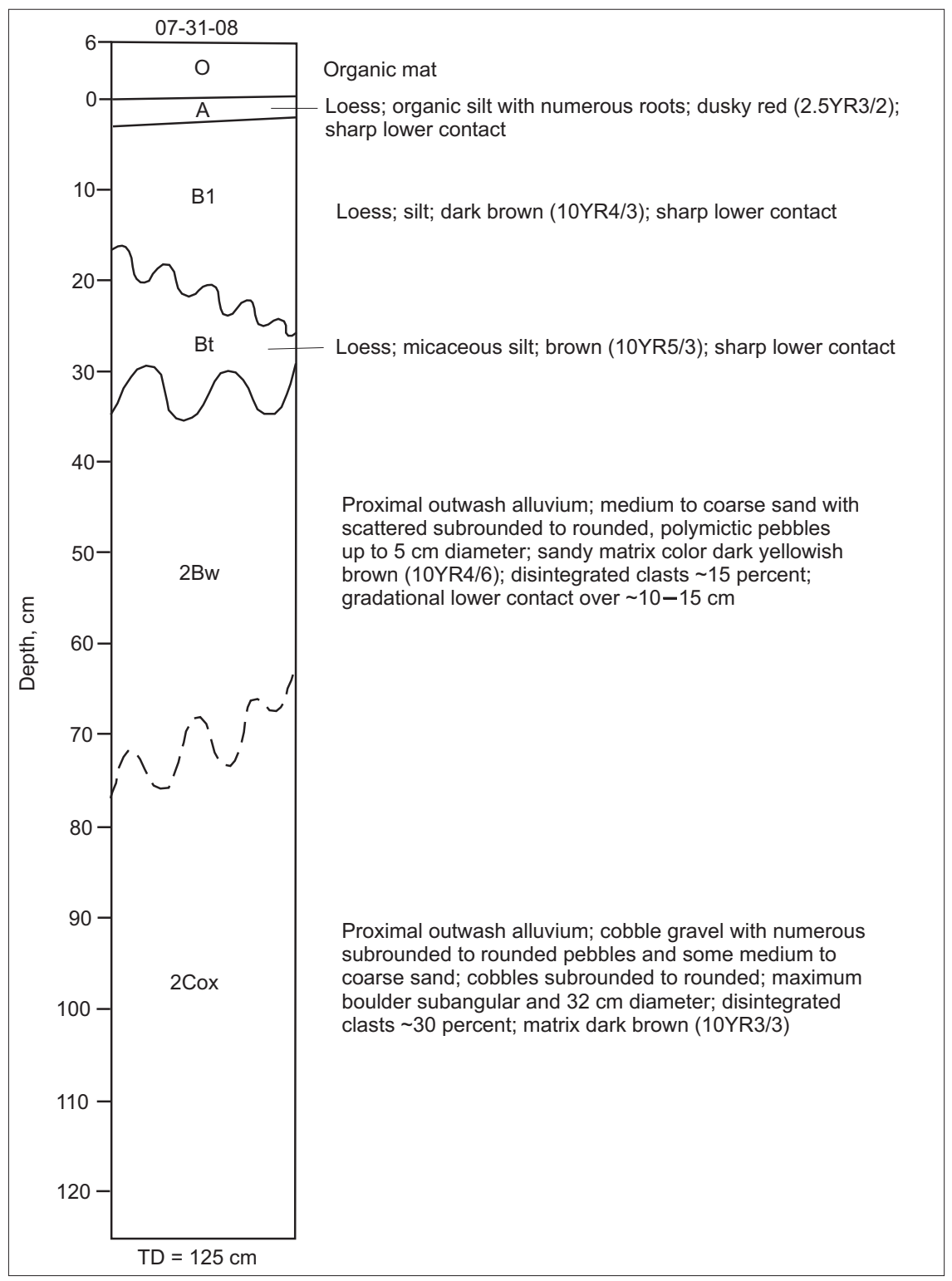

Figure 8. Soil profile (SP-7) in proximal outwash of Delta age in east-central Tanacross B-6 Quadrangle. Elevation 1,600 ft (488 m). 
Below an elevation of $\sim 3,500 \mathrm{ft}(\sim 1067 \mathrm{~m})$, the valley of the Tok River is clearly inset into the dissected upland surface to the northwest and southeast (fig. 5). Changes in the slopes of the walls of the Tok River valley at $\sim 3,500$ $\mathrm{ft}(\sim 1067 \mathrm{~m})$ and $\sim 2,500 \mathrm{ft}(\sim 762 \mathrm{~m})$ elevation along the profile could mark the upper limits of early and late phases of the Delta glaciation. Foster (1970) mapped discontinuous lateral moraines to which she assigned a pre-Delta age along both sides of the Tok River valley almost to the range front. Based on the presence of a brunisol of variable thickness on these features and numerous well preserved erratics with significant weathering rinds, Duk-Rodkin and others (2004) correlated that brunisol with the Diversion Creek soil, which postdates the Reid glaciation in the Yukon Territory, and correlated the Tok River valley moraines with the Delta glaciation to the west and the Black Hills glaciation (Fernald, 1965b) to the east. We mapped a lateral moraine with Delta affinities to within $5 \mathrm{~km}$ of the southern boundary of the map area along the lower northwest wall of the lower Tok River valley.

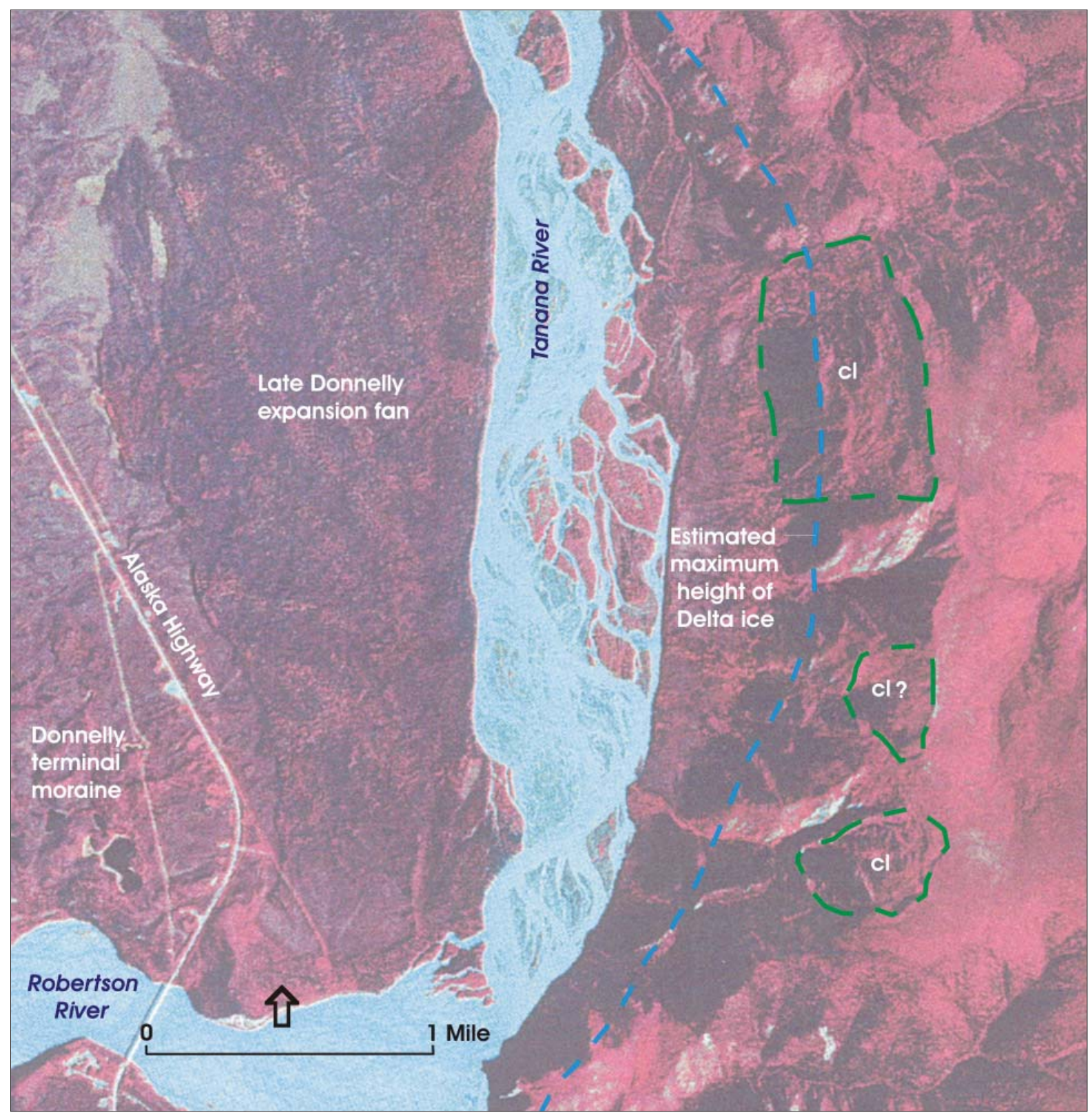

Figure 9. Airphoto showing estimated maximum height of glacial ice during Delta glaciation and failures (cl) in granitic bedrock, Tower Bluffs, Tanacross B-6 and C-6 quadrangles (Alaska High Altitude Photograph ALK 60 CIR 8485 taken August 1980). 


\section{DONNELLY GLACIATION \\ Glacial features}

As discussed in Reger and others (2008a), moraines of the Donnelly glaciation of late Wisconsinan age are better preserved, have significantly more kettle lakes, and have higher relief than moraines of the Delta glaciation (fig. 10).

A post-Donnelly soil profile (SP-8) is exposed at the top of the highway cut through the prominent Donnelly terminal moraine of the Robertson River glacier (sheet 2). This profile features a weakly developed, 15- to 36-cmthick, dark yellowish brown (10YR4/4) Bw horizon developed in the near-surface till (fig. 11). The underlying Cox horizon is light olive brown (2.5Y5/4) in color, and the base of the weathered zone is $\sim 58 \mathrm{~cm}$ deep. An interesting

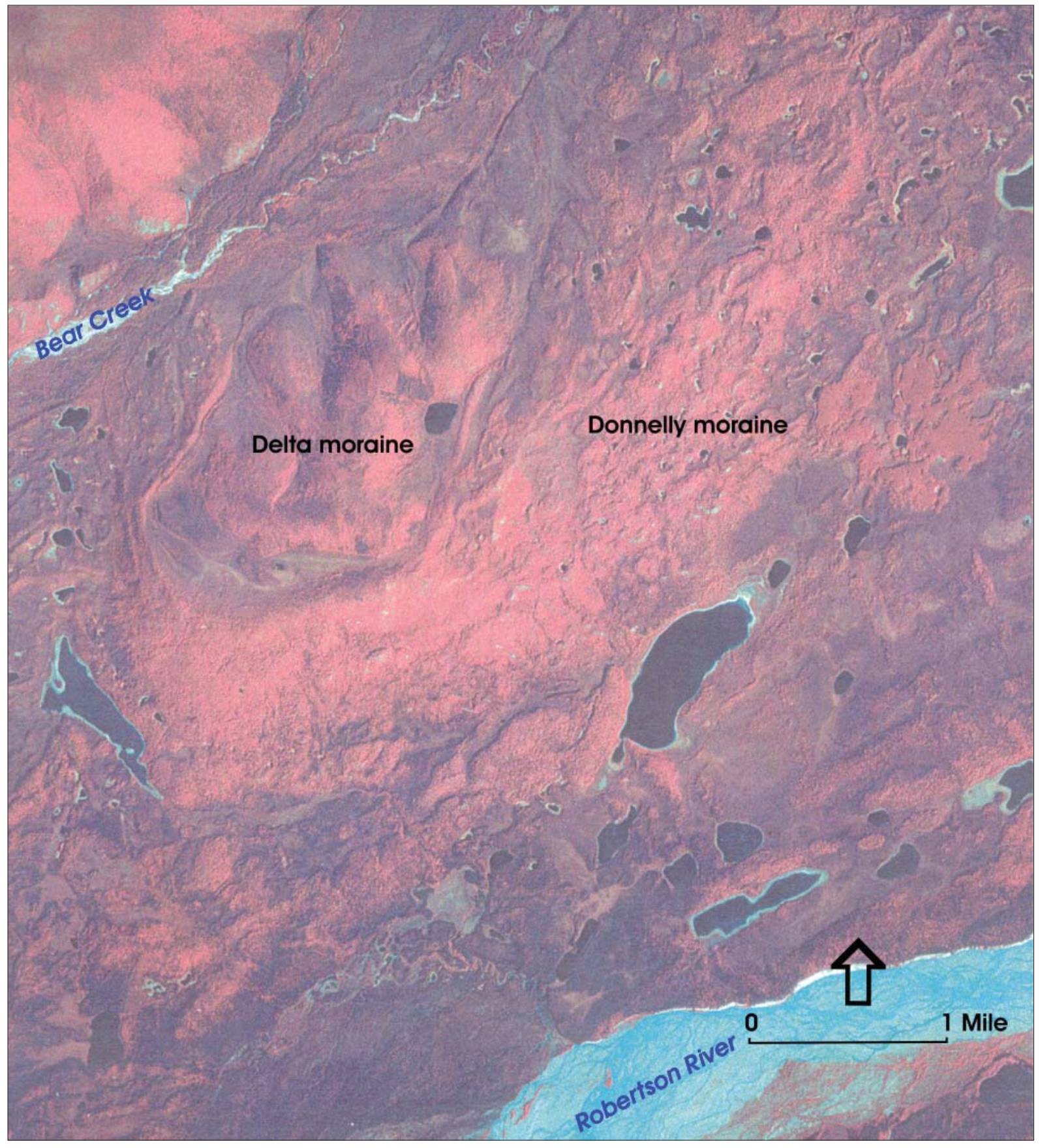

Figure 10. Airphoto comparing surface forms of Robertson River moraines of Delta and Donnelly ages in Mt. Hayes C-1 Quadrangle (Alaska High Altitude Photograph ALK 60 CIR 8487 taken August 1980). 
feature of this exposure is the presence of 5-mm-thick coatings of caliche that cement coarse sand grains to the bottoms of large clasts in the lower Cox horizon (fig. 12). The calcium carbonate for the coatings must have been introduced by calcareous dust deposited on this ridge crest because the exposure is well above present or past water tables.

A broad outwash fan extends northeastward toward the Tanana River from the Donnelly terminal moraine in the Robertson River valley (sheet 1). This fan is composed of coarse outwash gravel and is incised by a late Donnelly drainage channel (Qgfyy) that extends from an esker-kame complex around a bedrock knob to the Tanana River. This channel is likely the proglacial extension of the subglacial stream system that produced the esker-kame complex and likely was one source of outburst floods during late Donnelly glaciation.

Jan Lake is impounded in a reentrant in a bedrock hill behind outwash of Donnelly age. A 12,400 RC yr pollen record preserved in a core from the center of Jan Lake indicates that herbaceous tundra existed there near the end of the last major glaciation (Carlson and Finney, 2004) (sheet 1 and table 1, RC-4). A change to birch shrub tundra occurred $\sim 11,600 \mathrm{RC}$ yr ago, signaling the end of the Donnelly glaciation in this area. This record indicates that Jan Lake existed during Donnelly glaciation and the bedrock knob surrounding it was not ice covered.

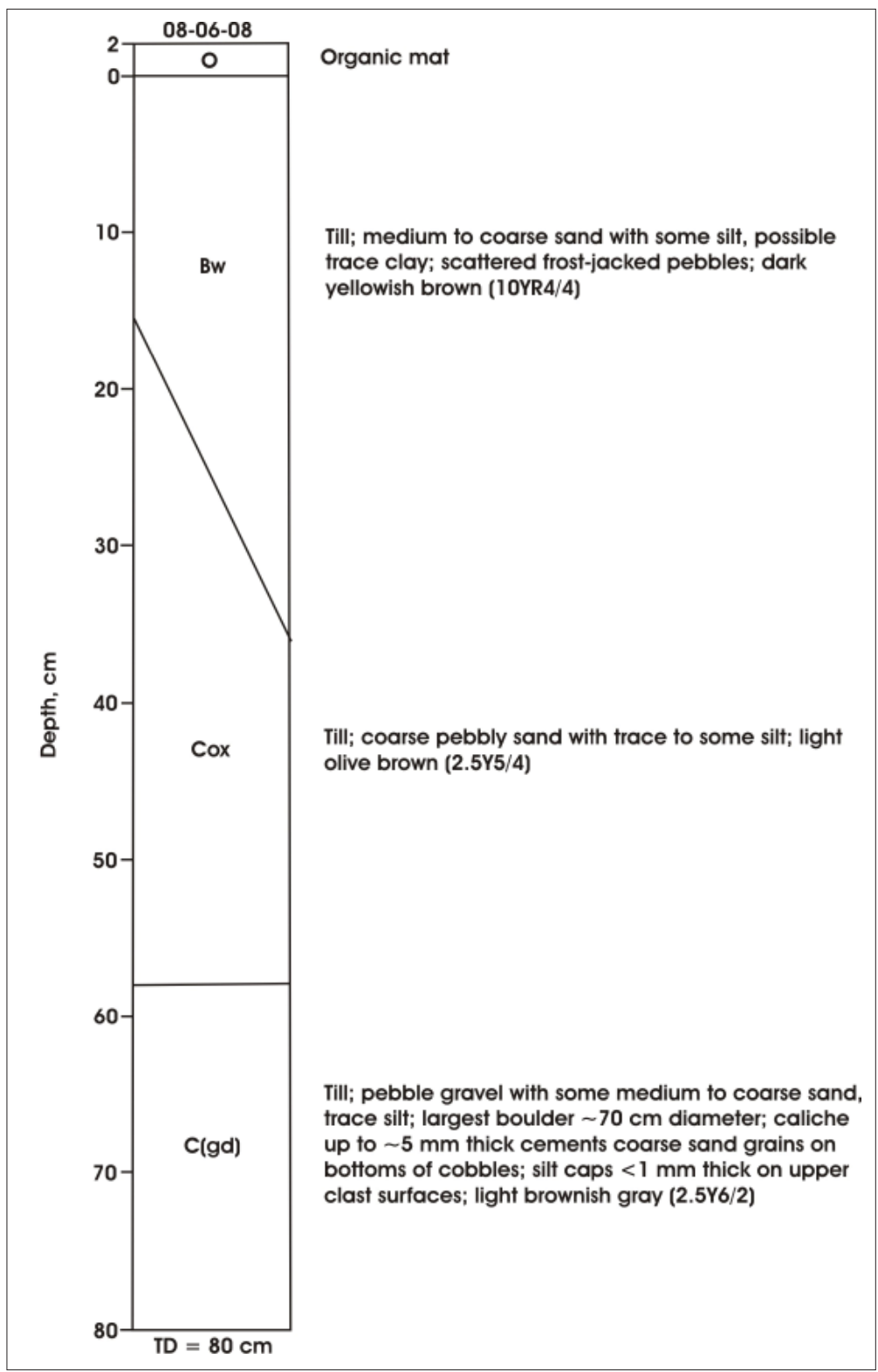

Figure 11. Diagram showing section of soil profile (SP-8) exposed in crest of highway cut through Donnelly terminal moraine of Robertson River glacier in northwestern Tanacross B-6 Quadrangle. Elevation $1,660 \mathrm{ft}(506 \mathrm{~m})$. 
Assuming a hypothetical former glacier thickness of at least $60 \mathrm{~m}$, projection of the minimum height of the Robertson River glacier during the Donnelly glaciation to the face of Tower Bluffs implies that Donnelly ice hypothetically may have reached an elevation of at least $\sim 1,715 \mathrm{ft}(\sim 520 \mathrm{~m})$ on the rock face and blocked the Tanana River, briefly forming an impounded lake of unknown extent (fig. 13). According to this model, the Donnelly-age glacier dam would have been roughly $65 \mathrm{~m}$ thick at Tower Bluffs, and the meltwater lake impounded upstream of the glacier probably would have reached no higher than $\sim 59 \mathrm{~m}$ to an elevation of $\sim 1,694 \mathrm{ft}(\sim 513 \mathrm{~m})$ before breaching the dam and flooding downstream. These outbursts probably would have been fairly frequent compared to more massive outbursts during the Delta glaciation.

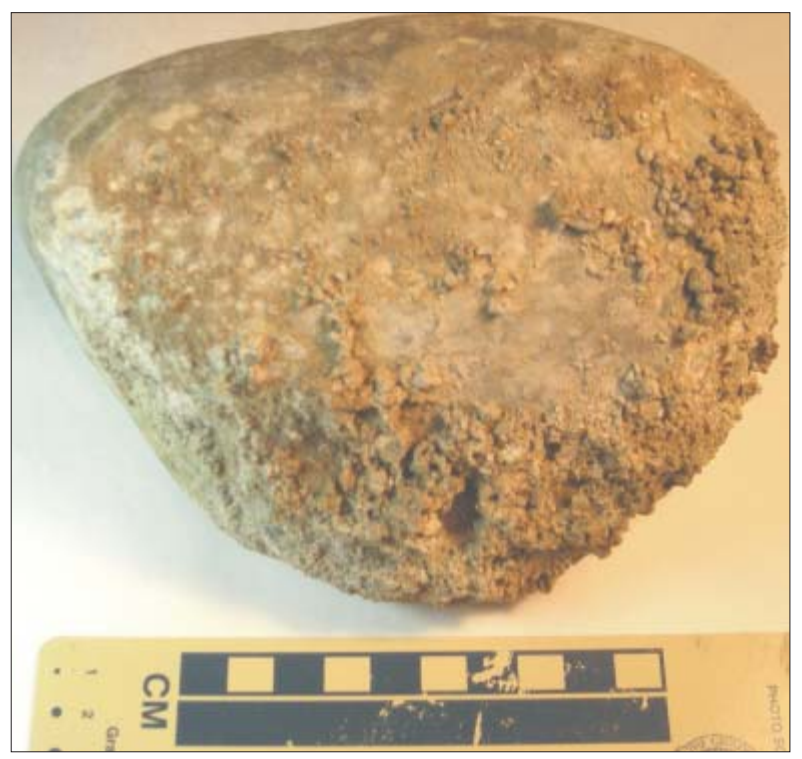

Figure 12. Photo showing 5-mm-thick layer of calichecemented coarse sand that coats lower surfaces of this noncalcareous metamorphic cobble from ablation till in Donnelly moraine exposed in highway cut in northwestern Tanacross B-6 Quadrangle. Scale in $\mathrm{cm}$.

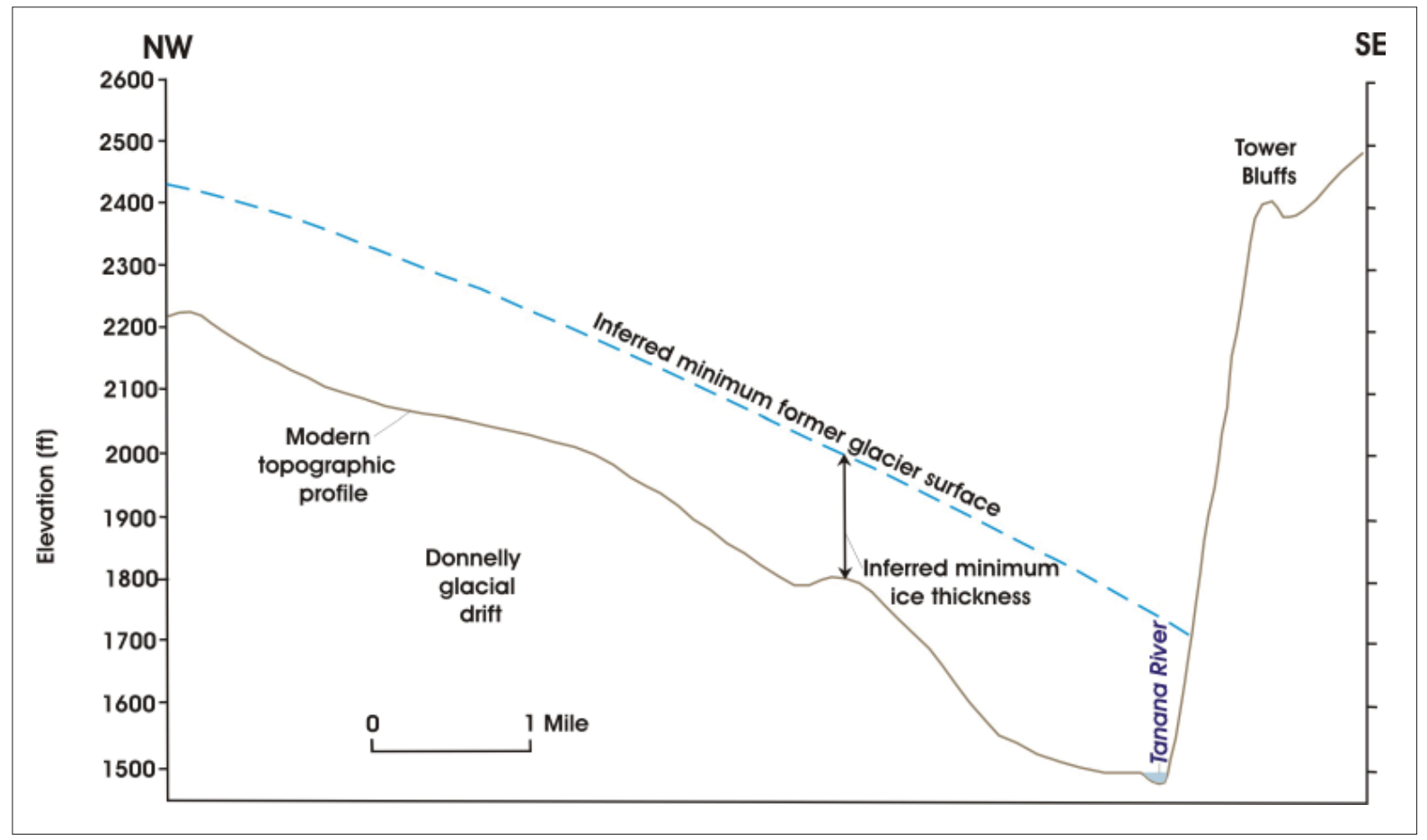

Figure 13. Model for blockage of Tanana River at Tower Bluffs by Robertson River glacier during Donnelly glaciation. 
During the Donnelly glaciation, morainal lobes and associated outwash fans were deposited by glaciers that occupied most higher alpine valleys on the northern flank of the eastern Alaska Range between the Robertson River and the Tok-Tanacross basin (Carrara, 2004a and b) (sheets 2 and 3). Of these glacial systems, the compound glacier in the Yerrick Creek drainage was the largest.

According to Schmoll (1984), the high-relief terminal moraine at Mineral Lake in the valley of Little Tok River, a tributary of Tok River $\sim 27.4 \mathrm{~km}$ up the Tok River valley from the corridor, most likely is late Wisconsinan in age and marks the maximum extent of Alaska Range ice in the Little Tok River valley during the Donnelly glaciation.

Table 1. Summary of radiocarbon dates associated with late Quaternary deposits in the Alaska Highway corridor, Tanacross Quadrangle.

\begin{tabular}{|c|c|c|c|c|c|}
\hline $\begin{array}{c}\text { Map } \\
\text { locality }^{a}\end{array}$ & $\begin{array}{c}\text { Material dated and } \\
\text { stratigraphic } \\
\text { context }\end{array}$ & $\begin{array}{l}\text { Chronological } \\
\text { significance }\end{array}$ & $\begin{array}{l}\text { Laboratory } \\
\text { number }\end{array}$ & $\begin{array}{l}\text { Radiocarbon age } \\
\text { (RC years B.P.) }\end{array}$ & Source \\
\hline $\mathrm{RC}-4$ & $\begin{array}{l}\text { Unidentified plant } \\
\text { fragments and Salix } \\
\text { twig at core depth } \\
\text { of } 364-365 \mathrm{~cm}\end{array}$ & $\begin{array}{l}\text { Age of dense gray silt } \\
\text { at bottom of core in } \\
\text { center of Jan Lake }\end{array}$ & $\begin{array}{l}\text { CAMS-58299 } \\
\text { CAMS-58298 }\end{array}$ & $\begin{array}{l}12,410 \pm 50 \\
12,430 \pm 40\end{array}$ & $\begin{array}{l}\text { Carlson and } \\
\text { Finney (2004) }\end{array}$ \\
\hline RC-5 & $\begin{array}{l}\text { Salix fragments near } \\
\text { top of poorly } \\
\text { laminated organic } \\
\text { clayey silt beneath } \\
\text { 15-m-thick } \\
\text { lacustrine sand }\end{array}$ & $\begin{array}{l}\text { Maximum age of } \\
\text { lacustrine sand in } \\
\text { lower Porcupine } \\
\text { Creek area }\end{array}$ & Beta-171226 & $41,880 \pm 470$ & $\begin{array}{l}\text { Carrara } \\
(2006)\end{array}$ \\
\hline RC-6 & $\begin{array}{l}\text { Shells of small } \\
\text { bivalves near top of } \\
\text { well-bedded } \\
\text { lacustrine sand }\end{array}$ & $\begin{array}{l}\text { Close minimum age } \\
\text { for lake dammed } \\
\text { behind sand dunes } \\
\text { along Taylor Highway } \\
\text { in upper Porcupine } \\
\text { Creek area }\end{array}$ & WW-3861 & $12,515 \pm 40$ & $\begin{array}{l}\text { Carrara } \\
(2006)\end{array}$ \\
\hline RC-7 & Charcoal & $\begin{array}{l}\text { Dates younger eolian } \\
\text { sand of Tetlin } \\
\text { Junction dune field }\end{array}$ & Beta-252314 & $8,100 \pm 40$ & This study \\
\hline $\mathrm{RC}-8$ & Grass and bark & $\begin{array}{l}\text { Dates abandoned- } \\
\text { channel deposits of } \\
\text { younger Tok fan }\end{array}$ & Beta-252318 & $2,540 \pm 40$ & This study \\
\hline RC-9 & $\begin{array}{l}\text { Small gastropod } \\
\text { shells from } 2-\mathrm{cm}- \\
\text { thick gray silt at } \\
\text { depth of } \sim 30 \mathrm{~cm} \text { in } \\
\text { terrace } \sim 5-6 \mathrm{~m} \\
\text { above Tanana River }\end{array}$ & $\begin{array}{l}\text { Dates fluvial terrace } \\
\text { deposits between } \\
\text { mouth of Porcupine } \\
\text { Creek and crossing of } \\
\text { Tanana River by } \\
\text { Alaska Highway }\end{array}$ & WW-5139 & $11,715 \pm 40$ & $\begin{array}{l}\text { Carrara } \\
(2006)\end{array}$ \\
\hline $\mathrm{RC}-10$ & $\begin{array}{l}\text { Salix fragments from } \\
\text { black woody peat at } \\
\text { depth of } 1.2 \mathrm{~m} \text { in } \\
\text { fine-grained } \\
\text { floodplain alluvium }\end{array}$ & $\begin{array}{l}\text { Dates abandoned } \\
\text { Tanana River } \\
\text { floodplain between } \\
\text { mouth of Porcupine } \\
\text { Creek and crossing of } \\
\text { Tanana River by } \\
\text { Alaska Highway }\end{array}$ & WW-5158 & $1,610 \pm 40$ & $\begin{array}{l}\text { Carrara } \\
(2006)\end{array}$ \\
\hline
\end{tabular}

${ }^{a}$ Numbers for sample localities in sheets 1-4 continue from designations for radiocarbon-sample localities in Reger and others (2008a, sheets 1 and 2). 
Thus, glacial ice did not advance into the Tanana River valley from the Tok River drainage during the last major glaciation. The absence of glacial moraine deposits at the mouth of the Tok River supports this interpretation.

\section{Eolian activity during Donnelly glaciation}

Foster (1970) assigned the widespread, thick dune complex in the Porcupine Creek-Tetlin Junction area (sheet 4) to the Donnelly glaciation. According to Foster and Keith $(1969$, p. 6), the eolian sands in this complex are composed of $\sim 50$ percent quartz, feldspar, and fragments of granitic and metamorphic rocks, 35 percent dark gray to black rock fragments, and $\sim 2$ percent magnetite. They did not identify the remaining 13 percent. Our field observations indicate that the yellowish brown (10YR5/4) to dark grayish brown $(2.5 \mathrm{Y} 4 / 2)$ sands of the Tetlin Junction dunes are covered with $\sim 18 \mathrm{~cm}$ of reddish brown (10YR5/3) to pale brown (10YR6/3) Holocene loess that includes the 1- to 3-cm-thick White River Ash.

Radiocarbon dates bracket the age of sand dune activity in the Porcupine Creek-Tetlin Junction area. Fragments of willow wood from poorly laminated clayey silts beneath sandy lake deposits along lower Porcupine Creek are dated at 41,880 \pm 470 RC yr B.P. (Carrara, 2006, Beta-171226) (table 1 and sheet 4, RC-5), providing a close maximum age for the lacustrine sand there and a less restrictive maximum-limiting age for deposition of the sand dunes.

At $\sim 1,900 \mathrm{ft}(\sim 576 \mathrm{~m})$ elevation in a roadcut at milepost 5.9 Taylor Highway, Foster and Keith $(1969$, p. 6$)$ found white fossil shells of clams and snails in interbedded silt and sandy silt that were deposited in a former local lake. Carrara (2006) dated shells from a narrow zone near the top of the roadcut at 12,515 $\pm 40 \mathrm{RC}$ yr B.P. (Carrara, 2006, WW-3861) (table 1 and sheet 4, RC-6), proving that the clearwater lake was impounded late in the Donnelly glaciation. We believe that this local lake was dammed behind the advancing Tetlin Junction sand dunes. A modern example of this type of dune-dammed lake, informally called 'Tetlin Dunes Lake', is $\sim 3.2 \mathrm{~km}$ south-southwest of the fossil locality (sheet 4 ). The former clearwater lake was eventually drained by headwater cutting of the 60-m-deep canyon of lower Porcupine Creek. The age of the shells in the lake sediments establishes a maximum age for draining of the former lake. At the Taylor Highway locality we collected a large number of white clam shells, which are all of the same species, have a maximum length of $4 \mathrm{~mm}$, and a height:length ratio of $0.75-0.875$. Shells are typically covered with fine, concentric striae and many have prominent annuli. Hinge plates are very narrow and short, and cardinal teeth are narrow and tiny. On the basis of their small size, shape, hinge characteristics, and location relative to the known distributions of other species of Sphaerium, we identify these small fingernail clams as Sphaerium (Sphaerium) nitidum Clessin, 1876, the Arctic-Alpine Fingernail Clam, which is widely distributed in arctic and subarctic cold-water lakes and in some rivers on various substrates (Clarke, 1981, p. 366-367). No aquatic gastropod remains were found in the roadcut despite a diligent search ${ }^{5}$.

In a roadcut through eolian sands of the Tetlin Junction dune field, we collected charcoal from a depth of 182 $\mathrm{cm}$ below the top of the roadcut. The age of $8,100 \pm 40 \mathrm{yr}$ B.P. (Beta-252314) (table 1 and sheet 4, RC-7) indicates that the dune field has been at least locally reactivated during the Holocene after wildfires destroyed the local vegetation (Kreig and Reger, 1982, pl. 9).

An interesting locality displaying evidence of past wind activity is the trachyandesite bedrock knob standing $\sim 64 \mathrm{~m}$ above the surface of the Tok fan $11.1 \mathrm{~km}$ west of Tok and $0.8 \mathrm{~km}$ north of the Alaska Highway (sheet 3, locality V-1). Although considerably disturbed by construction of a former tank farm associated with the local pump station, a layer of loess 30 to $50 \mathrm{~cm}$ thick remains on undisturbed surfaces and displays a post-Donnelly soil, indicating that the loess is probably Donnelly in age. On the south and southeast slopes of the isolated knob, about one-third of the fragments of the frost-rived volcanic bedrock in the shallow slope colluvium display features of ventifacts, including surface polish, shallow surface etchings, and shallow flutes and pits. Although pseudofacets formed by slight modification of joint surfaces are present, these rock fragments lack diagnostic surface features typical of well-formed ventifacts on landforms of Delta age in the Delta Junction-Fort Greely area (Reger and others, 2008a), such as sharp keels, obvious facets cut across clasts, and mineral grains standing several millimeters in relief. The largest ventifact found measures 24 by 16 by $11 \mathrm{~cm}$. Exposed surfaces of bedrock are slightly polished, but not modified further. Other slopes are heavily vegetated and were not examined. The distribution and relatively crude nature of the ventifacts indicate that cutting resulted from strong katabatic winds sweeping across the Tok fan, probably during the Donnelly glaciation.

\footnotetext{
${ }^{5}$ About $3.4 \mathrm{~km}$ southwest of the Taylor Highway locality, in the vegetated margin of 'Tetlin Dunes Lake', which was impounded in a reentrant in the bedrock ridge by the Tetlin Junction sand dunes, we collected the extant gastropod Stagnicola (Stagnicola) elodes (Say, 1821), the Common Stagnicola. This freshwater snail also lives in shallow gravel-pit lakes along the Alaska Highway $\sim 17.7 \mathrm{~km}$ west of Tok.
} 


\section{HOLOCENE GLACIATION}

Numerous Holocene end moraines and rock glaciers occupy upper mountain valleys in the Sheep Creek area of the eastern Alaska Range (sheet 2). Holocene moraines range in average elevation from $\sim 4,575$ to $\sim 5,810 \mathrm{ft}$ $(\sim 1,394$ to $\sim 1,771 \mathrm{~m})$, with a mean of $\sim 5,300 \mathrm{ft}(\sim 1,615 \mathrm{~m})(\mathrm{n}=10)$. Rock glaciers in the area range in average elevation from $\sim 4,275$ to $\sim 5,970 \mathrm{ft}(\sim 1,303$ to $\sim 1,818 \mathrm{~m})$, with a mean of $\sim 5,050 \mathrm{ft}(\sim 1,539 \mathrm{~m})(\mathrm{n}=16)$. Modern snowline, as indicated by a single small glacier in a west-facing cirque just south of the corridor, is at $\sim 5,470 \mathrm{ft}$ $(\sim 1,667 \mathrm{~m})$ elevation.

A small Holocene moraine, previously interpreted to be a rock glacier by Carrara (2004a), impounds a shallow tarn at the head of the west fork of Sheep Creek (sheet 1). A shallow test pit (SP-9) dug into this moraine exposed an inceptisol developed in coarse till of angular schist pebbles and cobbles (fig. 14). Loess (silt with trace fine sand) has infiltrated the open-work gravel to a depth of $\sim 30 \mathrm{~cm}$, and staining of till stones and their 3-mm-thick silt caps in the B horizon is dark reddish brown (5YR3/2). In the Cox horizon, silt caps are lacking, and spotty staining is reddish brown (5YR4/3) to dark reddish brown (5YR3/2).

Holocene outwash (Qgfh) is mapped only in the upper drainage of Sheep Creek (sheet 2).

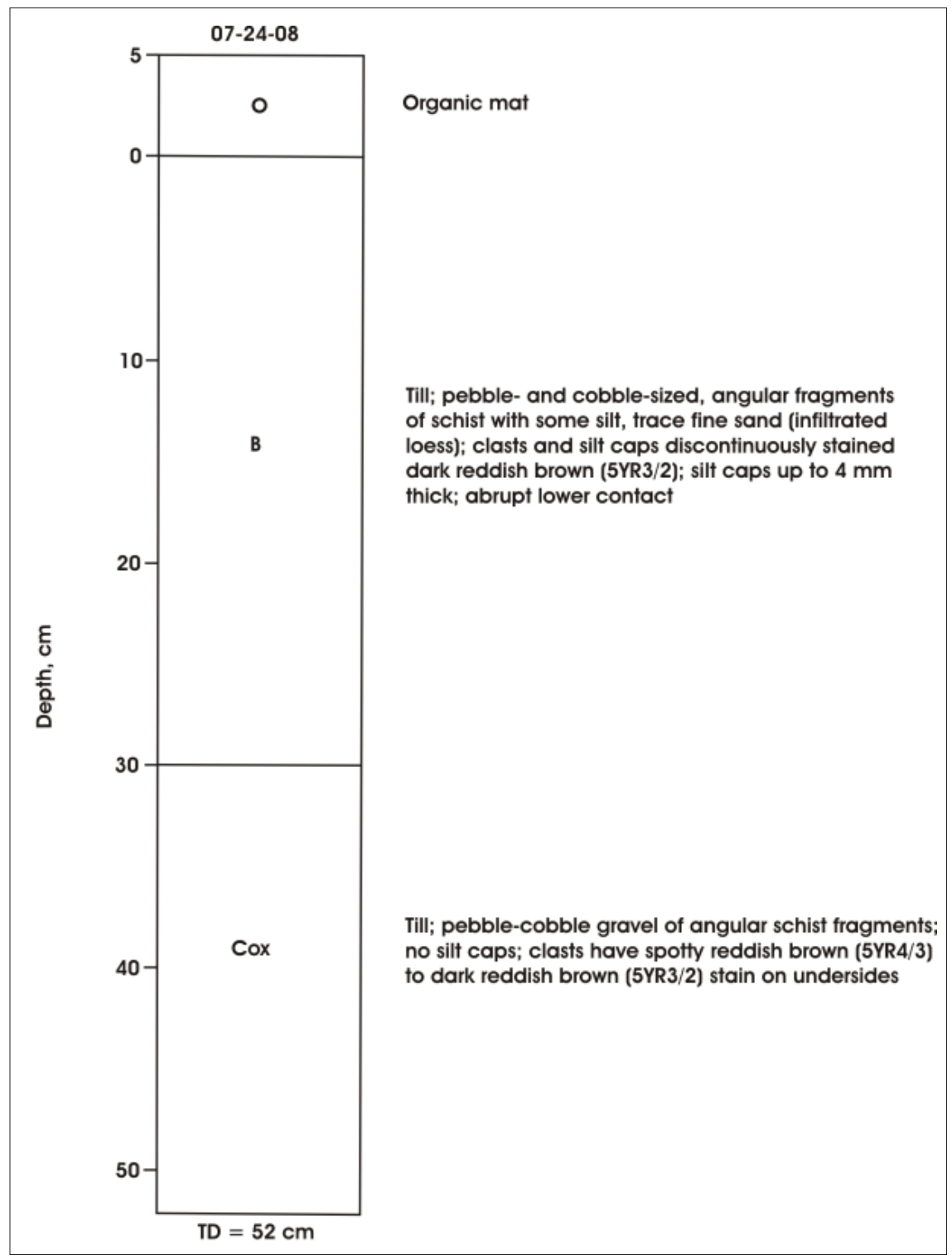

Figure 14. Section exposed in test pit (SP-9) in rounded crest of Holocene end moraine at head of west fork of Sheep Creek in northwestern Tanacross B-6 Quadrangle. Elevation $\sim 5,190 \mathrm{ft}(\sim 1,582 \mathrm{~m})$. 


\section{EVIDENCE OF PALEOFLOODS}

\section{FEATURES WEST OF CATHEDRAL BLUFFS}

From Cathedral Bluffs down the Tanana River to the western limit of the Tanacross Quadrangle, landforms related to past flooding are similar to landforms identified in the Mt. Hayes Quadrangle to the west (Reger and others, 2008a, sheet 2), including gravel expansion fans and fine-grained slackwater-basin deposits (sheets 1 and 2). The limited extent of the Delta terminal moraine and truncation of the Donnelly terminal moraine in the vicinity of Tower Bluffs at the Robertson River are likely due to massive outburst flooding from the Tok-Tanacross basin, much like terminal moraines were probably limited in extent by flooding at the Johnson River (Reger and others, 2008a). Otherwise, we recognize no evidence of outburst flooding during the Delta glaciation in this reach. Evidence of late Donnelly flooding of the Tanana River in the Tower Bluffs area is the large expansion fan that cuts through the Donnelly terminal moraine (fig. 9) and the flood-scoured bedrock knobs downstream of the expansion fan (sheet 1).

Between Tower Bluffs and Cathedral Rapids, expansion-fan deposits of Donnelly age and associated Holocene sand dunes are preserved on terraces east of the Tanana River (sheet 1) (Carrara, 2004a). A test pit (SP-10) dug into the Donnelly expansion fan on the terrace 7.6 to $9.0 \mathrm{~m}$ above the abandoned floodplain of the Tanana River exposed $23 \mathrm{~cm}$ of loess bearing a post-Donnelly soil profile overlying matrix- and clast-supported pebble-cobble gravels in which disintegrated schist clasts vary from numerous in the upper gravel to rare near the bottom of the 52-cm-deep test pit (fig. 15). Closer to the river, expansion fans on lower terraces are Holocene (sheet 2).

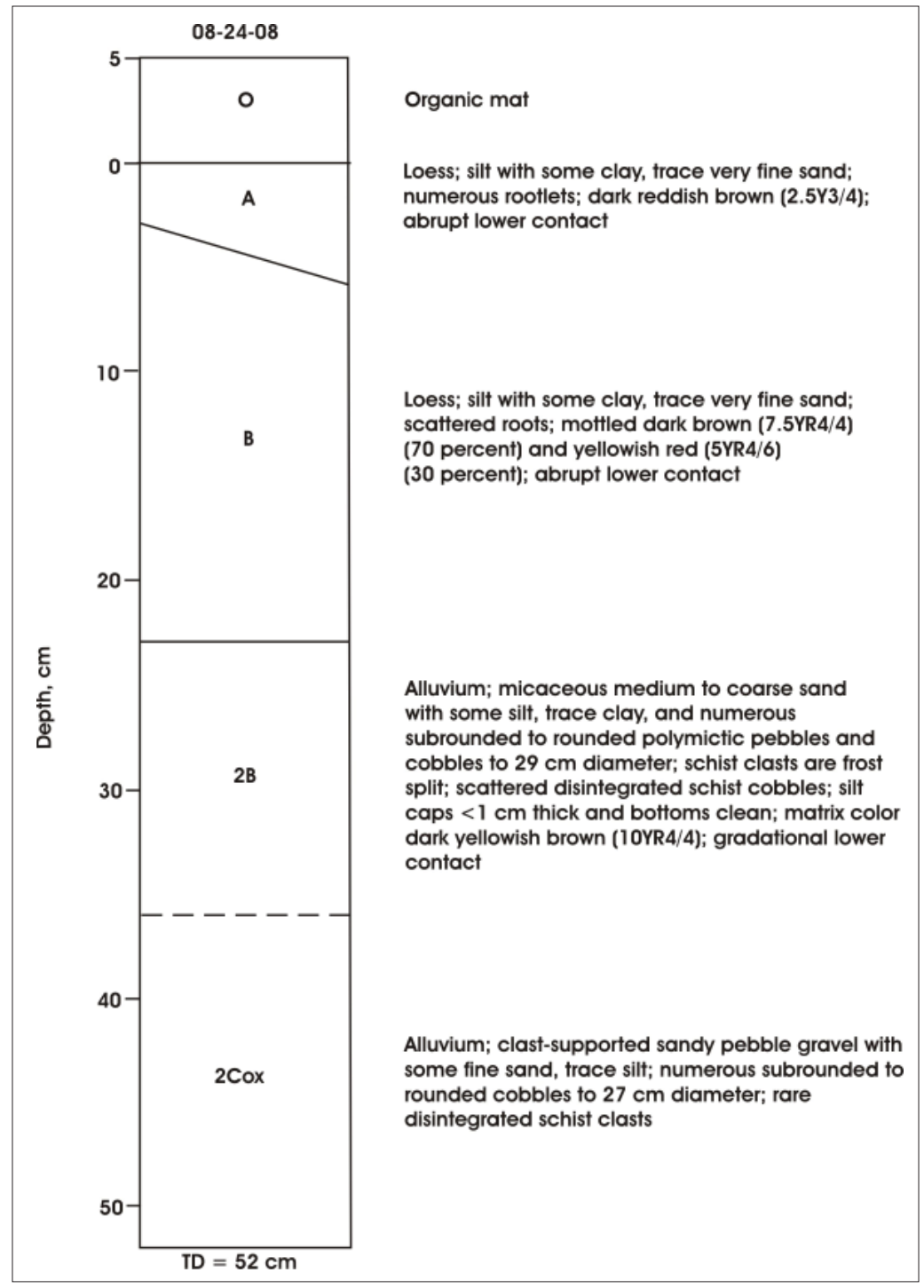

Figure 15. Section exposed in test pit (SP-10) in expansion fan of Donnelly age in northwestern Tanacross B-6 Quadrangle. Elevation $\sim 1,560 \mathrm{ft}(\sim 475 \mathrm{~m})$. 


\section{FEATURES EAST OF CATHEDRAL BLUFFS}

In contrast to reaches downstream, no expansion fans are recognized in the narrow corridor between Cathedral Rapids and the western limit of the Tok fan, and evidence of flooding is limited to features related to Holocene inundations of abandoned-floodplain surfaces by the Tanana River (sheets 2 and 3). We tentatively suggest that the lack of expansion fans in this reach may be related to the lack of an adequate upstream sediment source. We speculate that damming of the Tanana River downstream by advances of the Robertson River glacier during Delta and Donnelly glaciations could have briefly impounded lakes in this reach, although we have found no lake deposits or other evidence of impounded lakes, such as shoreline features. Nor have we found evidence that valley glaciers from the north flank of the eastern Alaska Range blocked the Tanana River upstream of the Robertson River.

\section{OLDER TOK FAN \\ General morphology}

The Tok fan, which occupies most of the Tok-Tanacross basin, was built by streams emanating from the Tok River valley (sheets 3 and 4). Although described as an alluvial fan (Williams, 1970, p. 43), this feature lacks properties attributed to typical alluvial fans, which include limited radial lengths (generally $<10$ to $15 \mathrm{~km}$ ), high values of radial slopes $\left(1.5^{\circ}\right.$ to $25^{\circ}$, which is equivalent to $\sim 26$ to $\sim 208 \mathrm{~m} / \mathrm{km}$ ), and planoconvex cross profile (Blair and McPherson, 1994, fig. 2). The Tok fan is up to $\sim 39 \mathrm{~km}$ wide, has radii that vary in length from $\sim 13$ to $\sim 42 \mathrm{~km}$, and the fan surface slopes from $\sim 1.4$ to $\sim 4 \mathrm{~m} / \mathrm{km}$ or $0^{\circ} 04^{\prime}$ to $0^{\circ} 14^{\prime}$. Like Foster (1970) and Carrara (2006), we recognize older and younger parts of the broad, low-gradient fan. The western, older, well-drained fan surface is 5 to $10 \mathrm{~m}$ higher than the inset younger, eastern fan surface.

On the higher, older fan surface, a series of 1- to 3-m-deep, digitate surface channels containing sand fills up to $\sim 0.3 \mathrm{~m}$ thick, which are locally cross bedded, radiate from the mouth of the Tok River valley toward the fan margins. We measured loess covers that average $\sim 15 \mathrm{~cm}$ thick but range from 5 to $56 \mathrm{~cm}$ on the older fan surface. According to John Burnham (07/25/2008 oral communication), the cover of silt on the Tok fan east of the Glenn Highway Tok Cutoff is generally $<0.3 \mathrm{~m}$ thick, although locally the silt is up to $3 \mathrm{~m}$ thick, and the thickness of silt increases close to the Tanana River. A typical post-Donnelly soil profile is developed on this surface (fig. 16). In a gravel pit in Tok, Duk-Rodkin and others (2004, p. 11) reported a 'truncated' 20-cm-thick red paleosol with typical clay skins that are characteristic of the Wounded Moose Palaeosol of the central Yukon, which is thought to predate the Delta glaciation, implying a middle Pleistocene age for the Tok fan (Reger and others, 2008a, table 1). We recognized no such soil in any of the many gravel-pit exposures we inspected in the older, western part of the Tok fan.

Based on his analysis of local water-well logs, Williams (1970) stated that the Tok fan alluvium is $>36 \mathrm{~m}$ thick at Tok, and the water table is between 16 and $21 \mathrm{~m}$ below the ground surface. Interpretation of EM1DFM model 12930 (fig. 17) ${ }^{6}$, which trends south-southeast to north-northwest across the Tok fan about halfway between Tok and Tanacross Airfield (sheet 3, profile A-A'), indicates that granular deposits in the Tok fan (Qfb) are $>100 \mathrm{~m}$ thick. Blue and green colors in EM1DFM model 12930 imply that the generally granular Tok fan contains small bodies of frozen, fine-grained deposits at depth south-southeast of the Alaska Highway, but the presence of these sediments has not been verified by subsurface data. Along the section, granular fan sediments abut a thick layer of discontinuously frozen, granular to fine-grained Tanana River deposits (Qa, Qab, Qat, Qfb) that in turn abut and overlie fine-grained and frozen lacustrine and slackwater basin sediments (Qfs) to the north-northwest.

\section{Fan sediments}

Examinations of numerous gravel pits in the older surface of the Tok fan indicate that this feature primarily is composed of massive pebble gravels with some medium to coarse sand, numerous cobbles, and rare boulders up to $\sim 30 \mathrm{~cm}$ in diameter. Clasts, which are generally subrounded to rounded and polymictic, generally increase in size toward the apex of the fan. In gravel exposures, Alaska Range lithologies dominate. Holmes (1965, table 4) segregated the lithologies of 100 clasts at five sites on the Tok fan into several classes: dense basalt (48-60 percent, average 54.2 percent), granitic (4-21 percent, average 12.6 percent), vesicular basalt (4-20 percent, average 10.8 percent), quartzite-quartz ( $3-14$ percent, average 7.6 percent), andesite ( $0-9$ percent, average 3.8 percent), gneiss-schist ( $0-7$ percent, average 3.4 percent), and miscellaneous (3-13 percent, average 7.6 percent). The significant percentages of volcanic lithologies are much different than in alluvial fans west of the Tok fan in the Tanana River valley and apparently represent an influx of sediment from volcanic terranes south of the Denali

\footnotetext{
${ }^{6}$ This model as well as differential resistivity and sengpiel sections and a geophysical dataset were developed during a geophysical survey of the Alaska Highway corridor (Burns and others, 2006). The inversion model was produced with 25 layers, each $4 \mathrm{~m}$ thick, to illustrate the resistivity properties of the surficial deposits and bedrock along the transect (L.E. Burns, 09/22/2009 written communication).
} 
fault (Richter, 1976). Fernald (1965a) attributed the source of volcanic tillstones in the upper Tanana River drainage to the Nabesna River, a tributary of the Tanana River that drains the Wrangell Mountains. However, we traced vesicular volcanic pebbles and cobbles in gravels for $\sim 80 \mathrm{~km}$ up the Tok River valley from the Tanana River, and we believe that glaciers from the Wrangell Mountains transported volcanic clasts into the headwaters of the Tok River, as suggested by Schmoll (1984).

Particularly instructive gravel exposures were discovered in Material Site 62-2-005-2 in an isolated remnant of the older, higher fan surface east of the Tok River (sheet 4, locality A). A $1.8 \mathrm{~m}$ greenstone boulder was exposed in place in clast- and matrix-supported gravels in the south pit wall (fig. 18). The bottom of the boulder was $2.4 \mathrm{~m}$ below the top of the gravel section in this wall. Near the center of the gravel pit, a pile of six very large boulders of granite, quartz schist, greenstone, and basalt, ranging in maximum diameter from 1.1 to 1.9 m (table 2), was evidence that several of these extraordinarily large rocks were encountered during pit excavation. ${ }^{7}$ The large insitu boulder was located in the upper part of a clean, clast-supported pebble gravel with numerous subrounded to

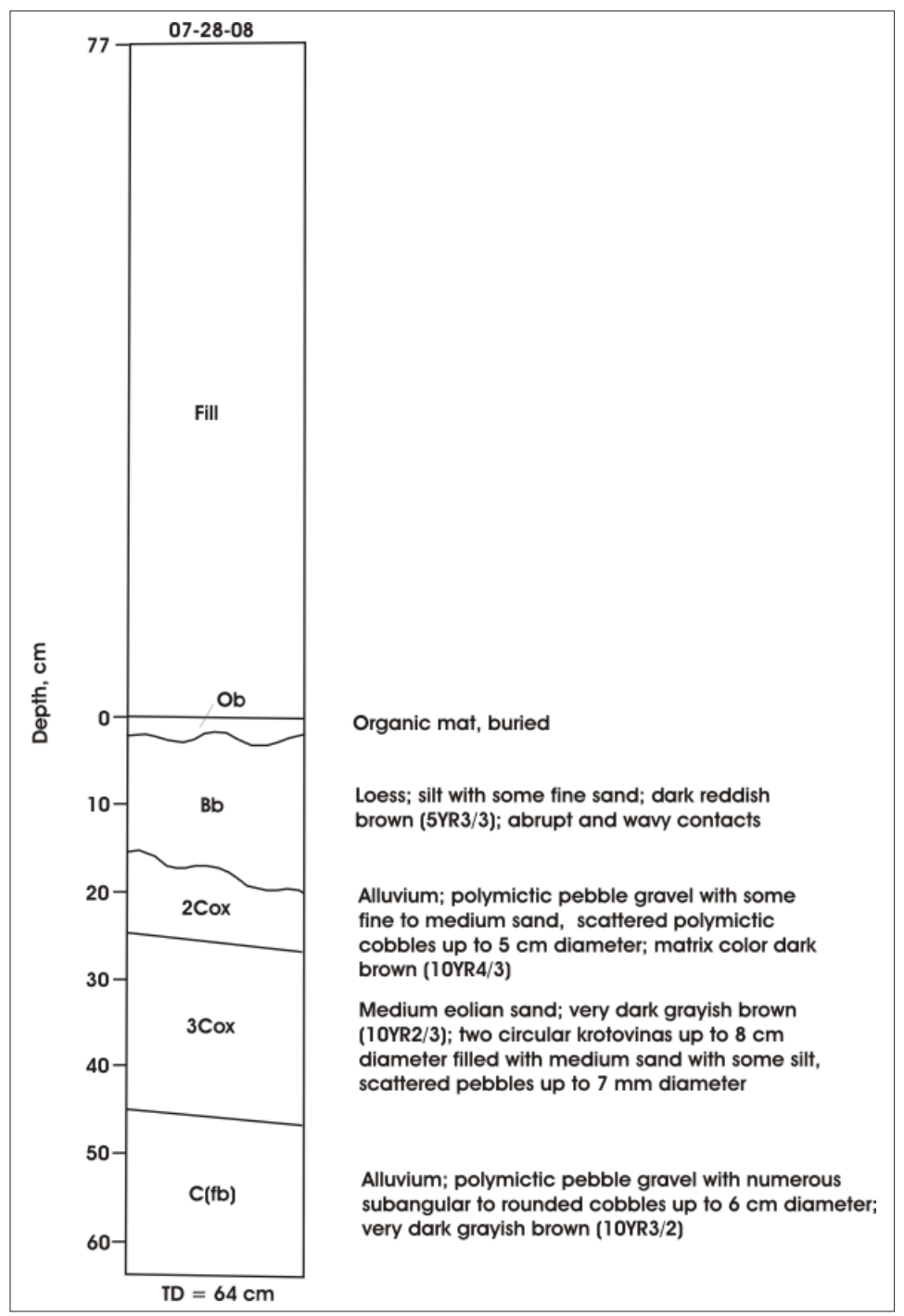

Figure 16. Soil profile (SP-11) exposed in west wall of M.S. 62-2-009-5 in western Tok fan in west-central Tanacross B-5 Quadrangle. Elevation 1,554 ft $(474 \mathrm{~m})$.

\footnotetext{
${ }^{7}$ Comparison of the modern gravel pit with July 1978 aerial photographs indicates that M.S. 62-2-005-2 has an area of $\sim 36.5 \times 10^{3} \mathrm{~m}^{2}$. When we first visited the pit on 07/27/2008, the pit had been excavated to an estimated average depth of $\sim 7.6 \mathrm{~m}$, indicating that $\sim 277.4 \times 10^{4} \mathrm{~m}^{3}$ of material had been removed. Assuming that no other boulders were encountered and later removed, an average of one exceptionally large flood boulder was present in every $\sim 46.2 \times 10^{4} \mathrm{~m}^{3}$ of gravel in this part of the Tok fan. Because a maximum of $9 \mathrm{~m}$ of gravel is exposed in the deepest part of the pit, the six large boulders were encountered within the upper $9 \mathrm{~m}$ of this deposit. During a 09/13/2010 visit to the pit after considerable construction expansion, we observed a newly accumulated pile of $\sim 30$ exceptionally large boulders of Alaska Range lithologies, including granitics, quartzites, and amygdaloidal metabasalts. The large greenstone boulder had been removed.
} 


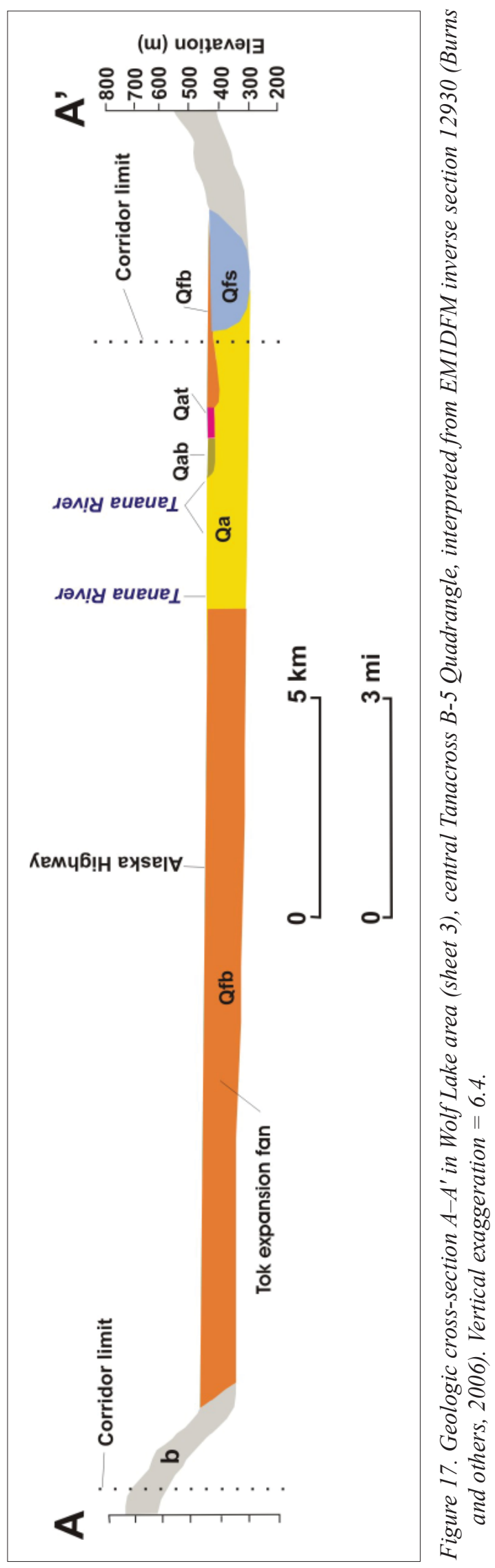




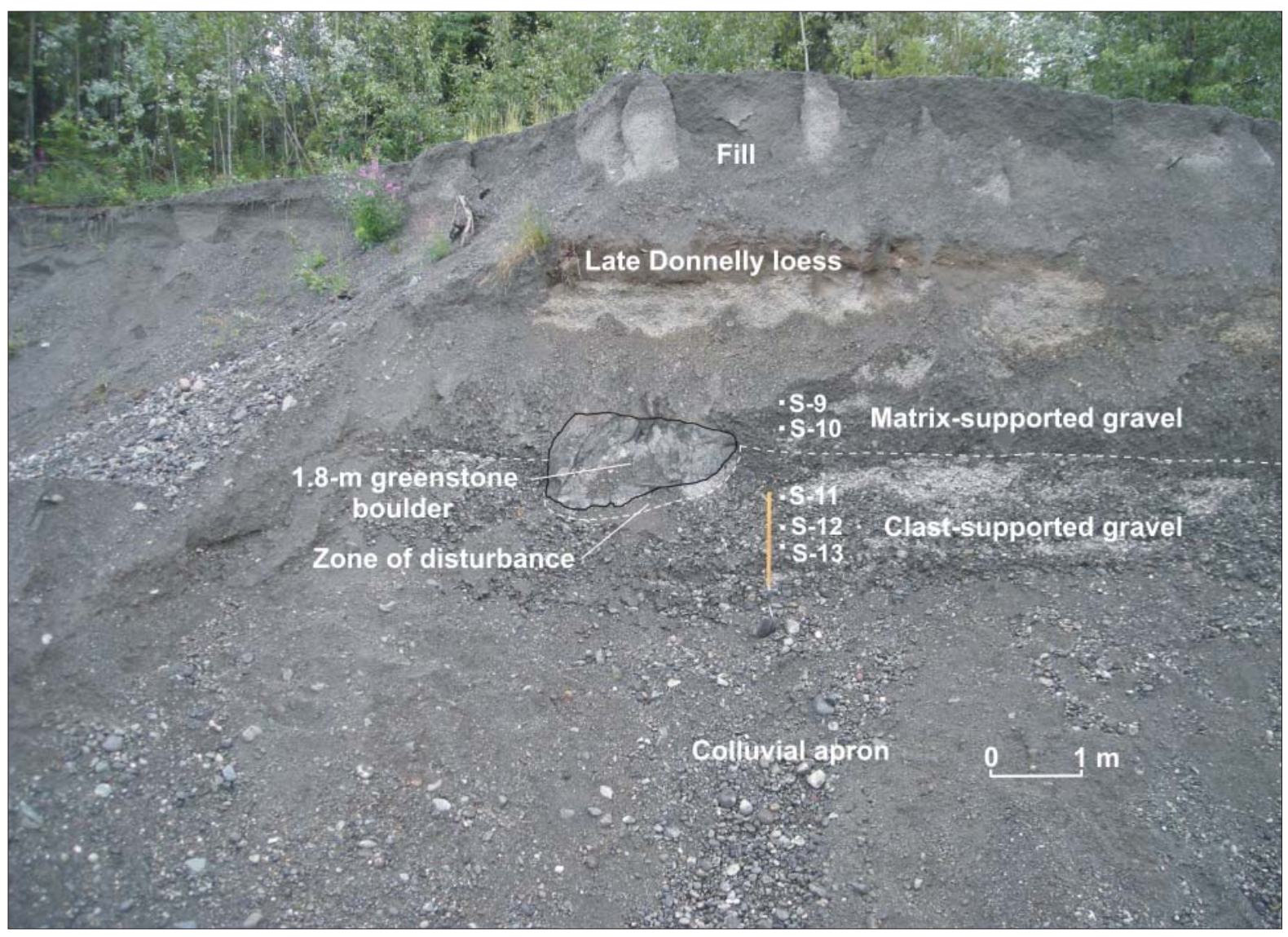

Figure 18. Photo showing extraordinarily large in-situ greenstone boulder (outlined for clarity) in clast-and matrixsupported gravels and sample locations in south wall of M.S. 622 005-2, northeastern Tok fan, Tanacross B-4 Quadrangle (sheet 4, locality A). Photograph taken 07/29/2008 by R.D. Reger.

Table 2. Dimensions of extraordinarily large boulders in northeastern Tok fan, and calculations for shape plot (fig. 21).

\begin{tabular}{|c|c|c|c|c|c|c|c|}
\hline $\begin{array}{c}\text { Map } \\
\text { locality }^{a}\end{array}$ & Latitude & Longitude & $\begin{array}{l}\text { Maximum } \\
\text { diameter } \\
\text { (cm) }\end{array}$ & $\begin{array}{l}\text { Intermediate } \\
\text { diameter } \\
(\mathrm{cm})\end{array}$ & $\begin{array}{c}\text { Minimum }^{b} \\
\text { diameter } \\
\text { (cm) }\end{array}$ & $\frac{\text { Minimum }}{\text { Maximum }}^{\mathrm{b}}$ & 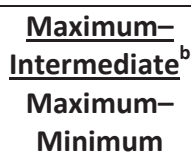 \\
\hline \multirow[t]{7}{*}{ A } & $63^{\circ} 19^{\prime} 22.4^{\prime \prime} \mathrm{N}$ & $142^{\circ} 48^{\prime} 47.0^{\prime \prime} \mathrm{W}$ & 210 & 80 & 70 & 0.33 & 0.93 \\
\hline & & & 190 & 140 & 100 & 0.53 & 0.56 \\
\hline & & & 194 & 170 & $100+$ & 0.52 & 0.26 \\
\hline & & & 105 & 90 & 70 & 0.67 & 0.43 \\
\hline & & & 130 & 100 & 70 & 0.54 & 0.50 \\
\hline & & & 130 & 110 & 60 & 0.46 & 0.29 \\
\hline & & & 110 & 80 & 80 & 0.73 & 1.00 \\
\hline \multirow[t]{5}{*}{ B } & $63^{\circ} 19^{\prime} 24.9^{\prime \prime} \mathrm{N}$ & $142^{\circ} 46^{\prime} 12.7^{\prime \prime} \mathrm{W}$ & 150 & 130 & $60+$ & 0.40 & 0.22 \\
\hline & & & 140 & 100 & 30 & 0.21 & 0.36 \\
\hline & & & 80 & 50 & 30 & 0.38 & 0.60 \\
\hline & & & 200 & 180 & 130 & 0.65 & 0.29 \\
\hline & & & 100 & 80 & 45 & 0.45 & 0.36 \\
\hline
\end{tabular}

${ }^{\text {a }}$ Sample localities $\mathbf{A}$ and $\mathbf{B}$ are shown on sheet 4 .

${ }^{b}+$ indicates that subminimum dimensions of partially buried boulders are used as minimum dimensions in the calculations. 
rounded, polymictic cobbles and a slight pebble imbrication that indicates flow from the head of the Tok fan. Five sandbag-sized samples were collected for preliminary granulometric analyses from the south wall of the gravel pit (fig. 18, appendix). Sieve analyses of samples S-11, S-12, and S-13 from the gravel, described as clast supported, in the south pit wall demonstrate that the matrix materials, which we define as sand, silt, and clay passing the \#10 U.S. Standard sieve, represent 4.0 to 12.0 weight percent of the sampled gravel (table 3 , appendix). Particularly noteworthy was the presence of an 11-cm-thick zone of disturbance beneath the boulder, perhaps indicating that the underlying material was deformed when the boulder was deposited. In this zone, pebbles were generally oriented parallel to the boulder surface; otherwise, the clast-supported gravel appeared massive. The large boulder and the clast-supported gravel were abruptly overlain, without evidence of scouring, by matrix-supported massive pebble gravel with scattered small cobbles (fig. 18). Sieve analyses of samples S-9 and S-10 demonstrate that the matrix material comprised 17 weight percent of the matrix-supported gravel samples in the south pit wall (table 3 , appendix). Beneath the fill at the top of the wall, a layer of loess $\sim 0.5 \mathrm{~m}$ thick displayed a post-Donnelly soil and is thought to be late Donnelly in age.

Inspection of the nearby pit walls indicated that the interbedded gravel and pebbly sand beds were generally massive, less than $1 \mathrm{~m}$ thick, tabular, had abrupt lower and upper contacts, and parallelled the fan surface. Cross bedding was not generally present. However, expansion of M.S. 62-2-005-2 during the 2010 construction season exposed a 1-m-thick pebble gravel bed with oblique tangential cross bedding dipping north-northeast in the southern pit wall. Two channel fills were identified, including a 50-cm-thick lens-shaped filling of massive sand in the south wall and a 1-m-thick channel fill of massive sand overlying clast-supported gravel in the west wall of the pit (fig. 19) ${ }^{8}$. Eight samples of clast- and matrix-supported gravels and pebbly sand (S-1 through S-8) were collected from the west wall of M.S. 62-2-005-2 and analyzed for grain-size distribution (fig. 20). Sieve analyses

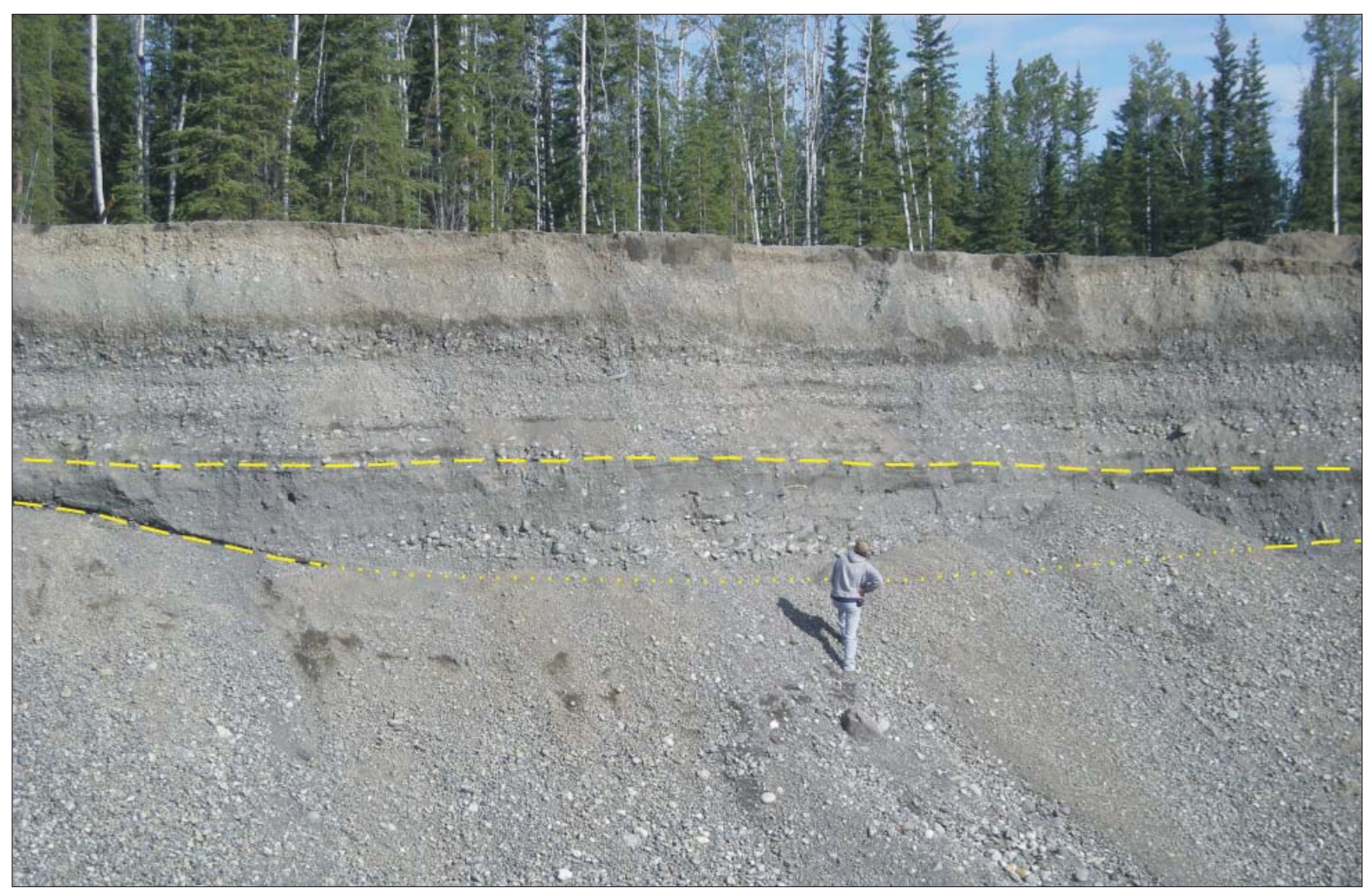

Figure 19. Photo showing cross section through large channel filling in west wall of M.S. 62 2 005-2, northeastern Tokfan, Tanacross B-4 Quadrangle (sheet 4, locality A). Contact dotted where inferred beneath colluvial apron. Person provides scale. Photograph taken 08/01/2008 by R.D. Reger.

\footnotetext{
${ }^{8}$ Near the base of the east wall of the Burnham gravel pit in Tok, we observed a cross-bedded channel fill of fine to very-fine sand in gravels of the older part of the Tok fan, indicating that some of these fills are locally cross bedded.
} 


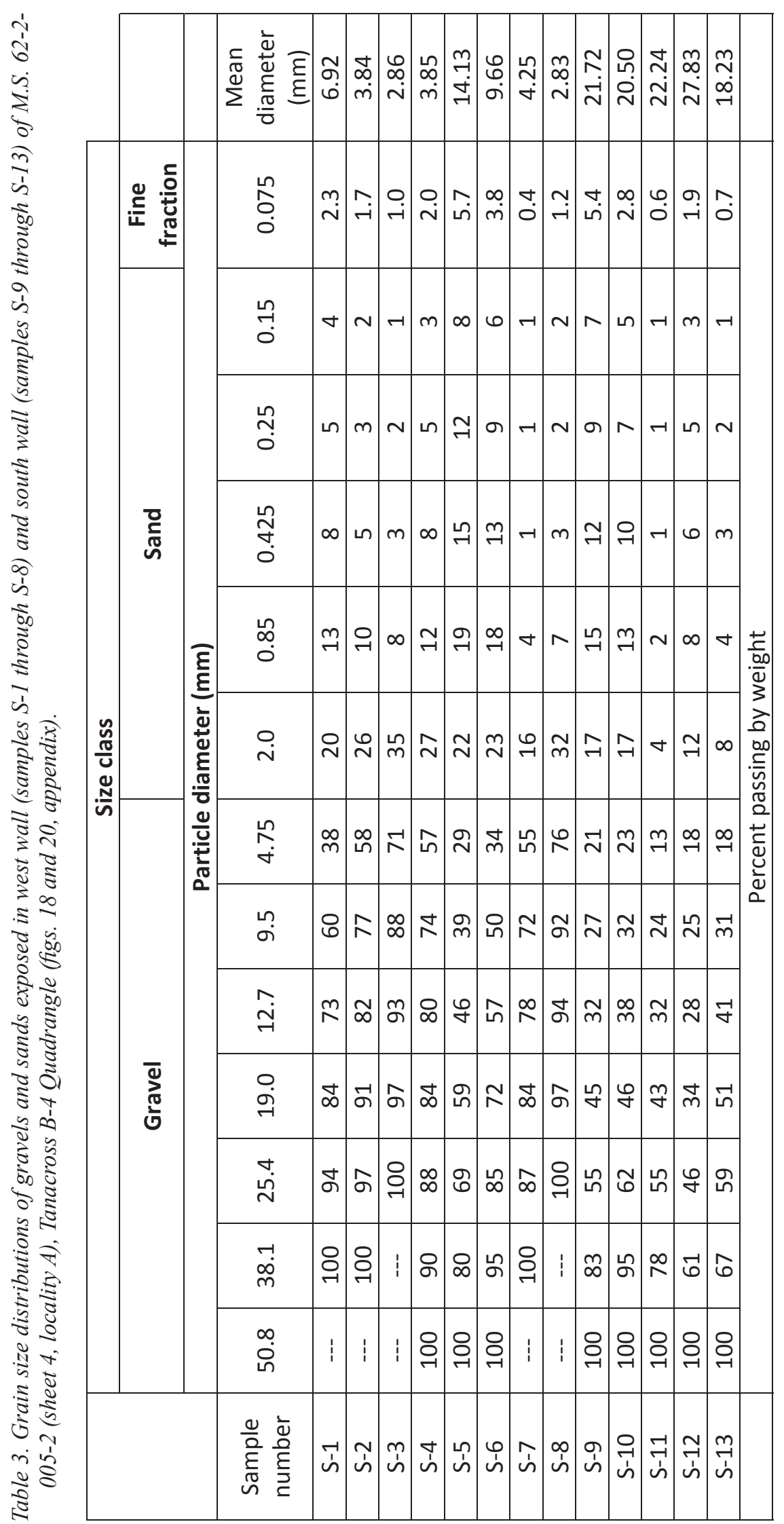




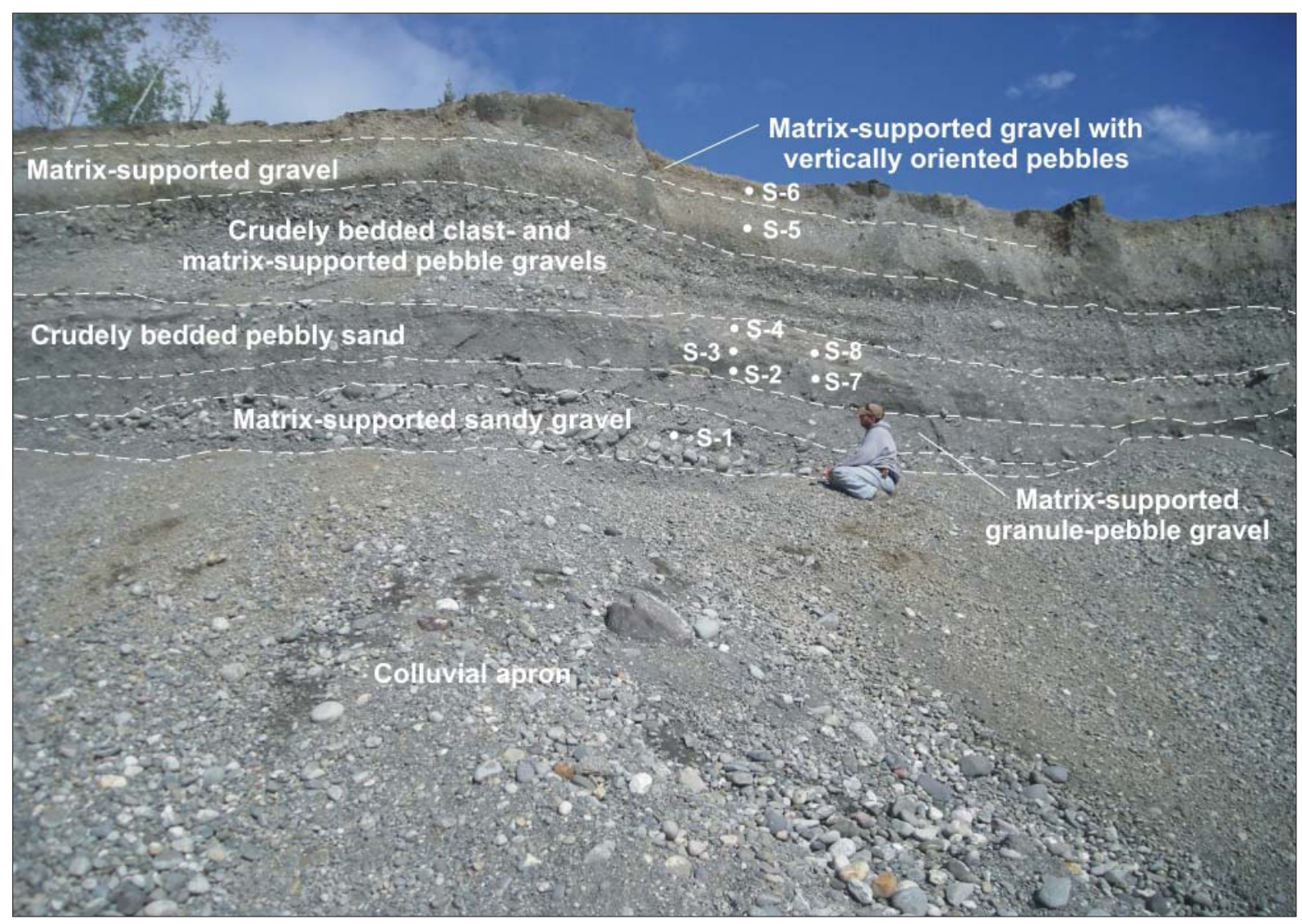

Figure 20. Photo showing locations of samples in exposed gravels and sands in west wall of M.S. 62-2-005-2, northeastern Tokfan, Tanacross B-4 Quadrangle (sheet 4, locality A). Photograph taken 08/01/2008 by R.D. Reger.

of gravels described as matrix supported in the west pit wall demonstrate that matrix materials represent 20 to 23 weight percent of the sampled gravels (table 3 , appendix). Materials passing the \#10 Standard sieve in samples S-2 through S-4 and S-7 and S-8 demonstrate that matrix materials represent 16 to 35 weight percent of the pebbly sand samples (table 3, appendix).

In summary, sieve analyses of gravels described as clast and matrix supported in the field demonstrate that clast-supported gravels contain less matrix material and matrix-supported gravels contain more sand and fine fraction (<\#200 Standard sieve). Logically, the weight percentages of sand, silt, and clay in pebbly sands overlap and exceed those components in matrix-supported gravels. However, we urge caution in defining the nature of the depositing medium only on the basis of textural values because a significant part of the suspended load could have remained in suspension due to turbulence and could have been flushed down the Tanana River (Smith, 1986, p. 5).

Particularly noteworthy, although not investigated in detail, is the ubiquitous presence of vertically oriented pebbles in matrix-supported gravel at the top of the section (fig. 20 and table 3, sample S-6). A possible explanation for the vertical pebble fabric is reorientation of pebbles by settling in liquefied gravels during strong earthquakes. We reject reorientation of the pebbles by frost jacking as a mechanism because of the ubiquitous distribution of the fabric.

A second locality where extraordinarily large boulders are present, although not in place, is near the east edge of the isolated remnant of the upper surface in the northeastern Tok fan (sheet 4, locality B). There, four rounded to subrounded boulders of conglomerate, amphibolite, and chlorite schist and one tabular boulder of amphibolite gneiss range in maximum diameter from 0.8 to $2 \mathrm{~m}$ (table 2). These lithologies are indicative of a source in the Alaska Range to the southwest (Foster, 1970; Richter, 1976).

A plot of the shapes of the extraordinarily large boulders at localities $\mathbf{A}$ and $\mathbf{B}$ (sheet 4) in the northeastern Tok fan displays a wide variation in form (fig. 21), similar to the triangular plot of granitic flood boulders found farther down the Tanana River drainage in the Mt. Hayes Quadrangle (Reger and others, 2008a, fig. 29). However, large boulders in the Tok fan do not display the rounded corners and edges of well-traveled granitic flood boulders in the Berry-Sears creeks reach of the Tanana River (Reger and others, 2008a and b). 


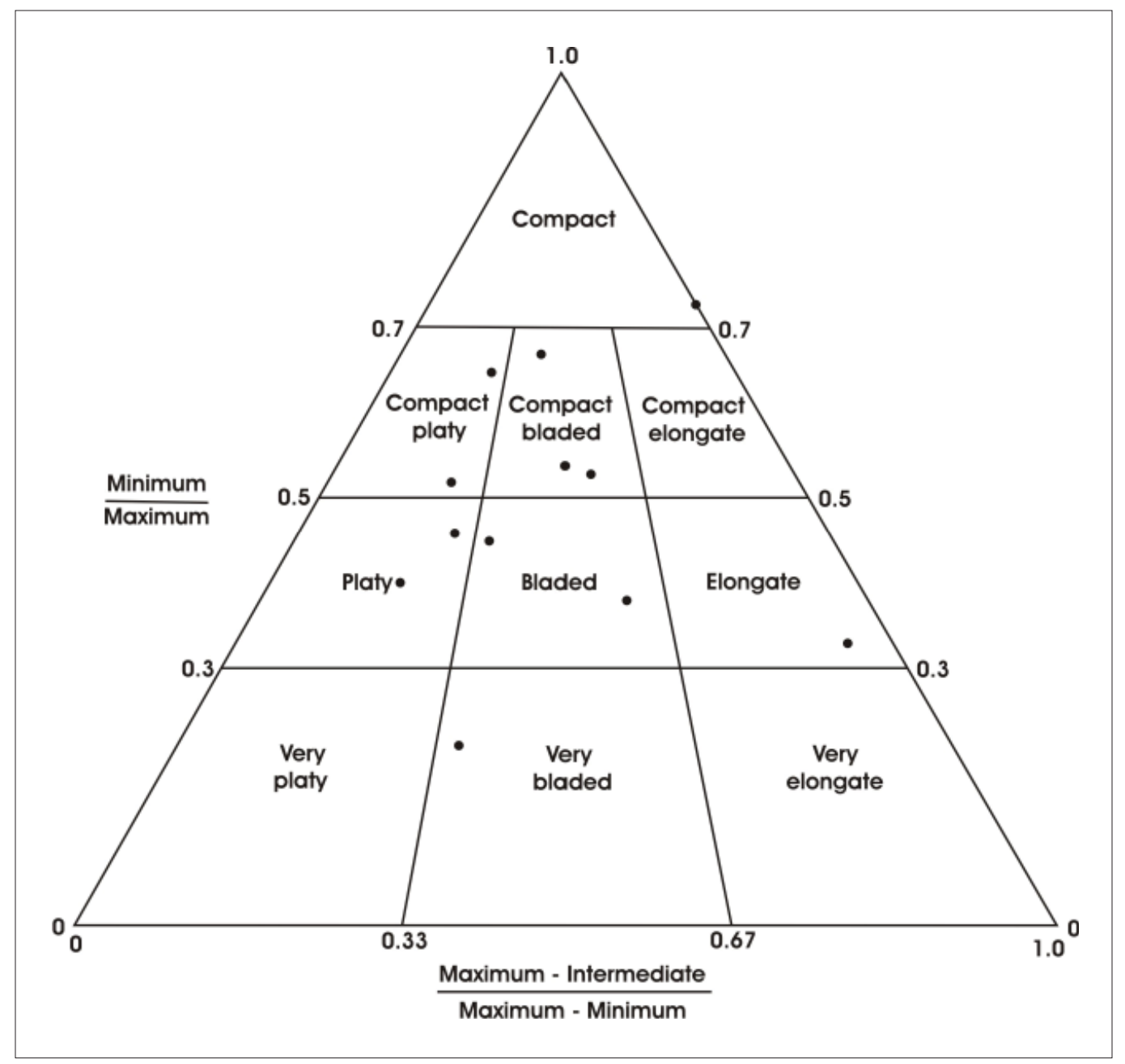

Figure 21. Diagram showing shape classes of extraordinarily large boulders $(n=12)$ in northeastern Tok fan (sheet 4, localities A and B), based on boulder dimensions (table 2) (classification of Sneed and Folk, 1958).

A third locality where a 2-m-diameter granitic boulder was recovered in the Tok fan is near the western edge of the high terrace at the crossing of the Tok River by the Alaska Highway (Glenn Burnham, 08/05/2008 oral commun.) (sheet 4, locality C), although the stratigraphic context of the boulder is unknown because it had been moved from its original location. We observed an anomalous, large boulder in the active meander channel of the Tok River $150 \mathrm{~m}$ upstream from the Alaska Highway and interpret that object as a lag boulder resting on the unconformity between the downcutting Tok River and the underlying Donnelly flood gravels. Nowhere else in the Tok fan have these extraordinarily large boulders been recovered, even in gravel pits as deep as $10.6 \mathrm{~m}$ (Glenn Burnham, 08/05/2008 oral commun.), and none were present in the several deep pits we inspected.

Age

Carter and Galloway (1978) apparently saw some of these large boulders, although likely not in place, and mapped the isolated terrace remnant as old glacial moraine (Qmo), which they correlated with Delta moraines to the west. Foster (1970) concluded that the terrace and the older part of the Tok fan west of the Tok River are genetically related and assigned a Delta age to both. Carrara (2006) recognized that both surfaces are equivalent and dated them as middle Pleistocene. Based on the presence of post-Donnelly soil profiles and the generally thin cover of loess, we believe that the older part of the Tok fan surface is Donnelly in age. 


\section{Depositional processes}

The lack of glacial till in any of the water wells or gravel-pit exposures in the Tok fan indicates that the extraordinarily large boulders were not deposited directly from glacial ice as inferred by Carter and Galloway (1978). The absence of stratigraphic features normally deposited by water floods, including cut-and-fill structures, ripples, and widespread cross bedding, indicates that the boulders were not deposited by typical water floods ${ }^{9}$. We propose that the very large boulder in the near-surface, massive, tabular, clast- and matrix-supported gravels and pebbly sands in M.S. 62-2-005-2 provide evidence that those large, uncommon boulders were deposited as dropstones from icebergs during massive outburst floods surging from the Tok River valley to the south and spreading as waves (sheetfloods) across the shallow fan surface (fig. 22). We speculate that those large boulders were initially

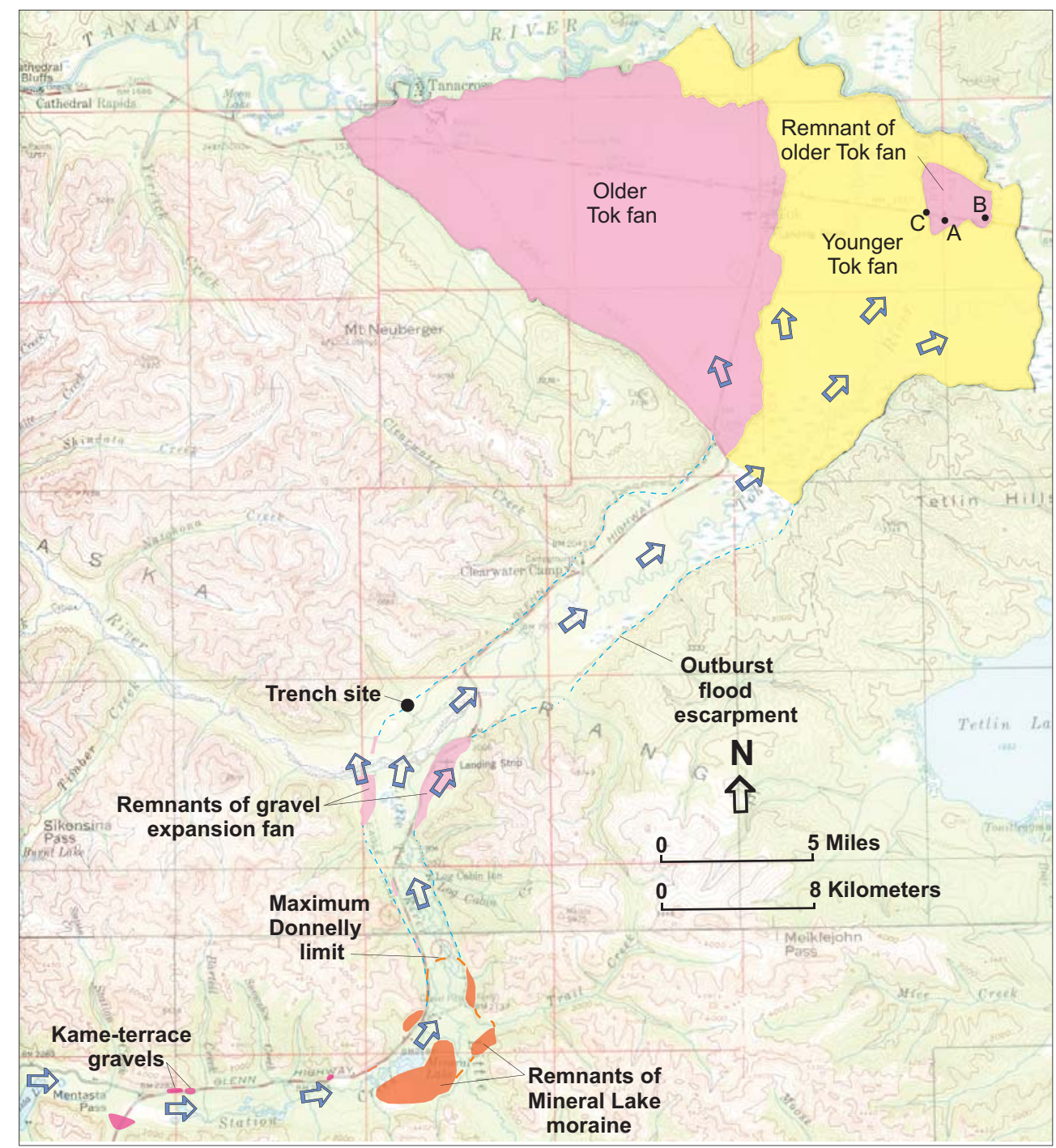

Figure 22. Map showing course of outburst floods (blue arrows) from Mentasta Pass to Tok fan during Donnelly glaciation relative to locations of flood boulders in northeastern Tok fan (sheet 4, localities A-C). Landforms in upper Tok River and Little Tok River valleys interpreted from Foster (1970) and Richter (1976) and verified by field observations. Flood escarpments dashed where discontinuous and dotted where buried and inferred. Asterisk marks site of trenches excavated by Carver and others (2010).

\footnotetext{
${ }^{9}$ Duk-Rodkin and others (2004) described coarse gravels containing 'truncated foreset beds' in a gravel pit at Tok. However, we found no foreset beds or significant cross bedding anywhere in the older part of the Tok fan.
} 
dumped near the sites of their ultimate burial and then may have been rolled across the fan surface a very short distance before being quickly buried by sediments carried in subsequent flood pulses. Large boulders carried or moved by the flood have been found in the Tok fan only in line with the trend of the Tok River valley, indicating that the boulder-bearing outburst floods came from that direction (fig. 22, localities A-C).

The interlayered nature of the tabular gravels and sands exposed in the walls of M.S. 62-2-005-2 and the clear difference in their compositions (fig. 23) indicate that the large-magnitude flows pulsated during the outburst flooding, perhaps as a result of two main hydraulic processes. First, temporary blockages of subglacial drainageways through which floodwaters bypassed the glacier dam could have generated flow pulses (Sturm and others, 1987; Sturm and Benson, 1989; Tweed and Russell, 1999). Second, pulsating hydraulic conditions could have resulted from supercritical flood flows released onto the Tok fan at the mouth of the Tok River valley and spreading as upper flow-regime sheet flows across the gently sloping fan surface (Blair and McPherson, 1994). We suggest that gravel-rich beds represent bedload components deposited by water-dominated flood surges and that pebbly sands and matrix-supported gravels preserve components of the suspended load that were deposited by watery hyperconcentrated flows (see sidebar). The lack of waning flood sands on the surface of the Tok fan could have resulted from their reworking into surface dunes or their removal to the southern Yukon-Tanana Upland by strong katabatic winds, similar to the deflation of late Pleistocene sand and loess from the Nenana River valley (Thorson and Bender, 1985). The older part of the broad Tok fan has the morphological characteristics, such as a low gradient, low relief, and a surface network of shallow distributary channels, of a fan dominated by sheetflooding (Blair and McPherson, 1994, fig. 1B).

Based on our tracing of vesicular-volcanic-bearing flood gravels and mapping of associated flood-related landforms up the Tok River valley through Mentasta Pass and in the lower Slana River valley, we modify the flood model proposed by Schmoll (1984). In his model, massive floods from glacial Lake Atna broke through a former ice dam of Alaska Range derivation in the Mentasta-Mineral lakes area and entered the headwaters of the Tok River. Instead, we propose that the significant damming of glacial Lake Atna occurred in the lower Slana River valley downstream of Mentasta Lake when large glaciers that advanced northward from the northeastern flank of the Wrangell Mountains entered the lower valley of the Slana River. Breaching likely occurred when rising waters of glacial Lake Atna floated this massive ice dam enough to allow floodwaters egress into the lower Slana River valley, from which they entered the valley of Station Creek. Kame terrace gravels containing vesicular volcanics are superimposed on till with Alaska Range lithologies in roadcuts through the Station Creek valley, and we speculate that floodwaters initially flowed along both sides of the late-Wisconsin glacier there. Breaching of the Mineral Lake moraine could have occurred when these ice-marginal floods overtopped the moraine (fig. 22). Floating of the glacier behind the Mineral Lake moraine may not have been significant.

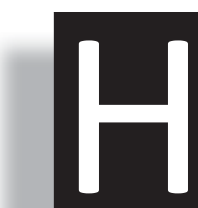

yperconcentrated flows are sedimentwater mixtures that are intermediate between water floods and debris flows and are heavily charged with suspended sediments (O'Brien and Julien, 1985; Pierson and Costa, 1987; Pierson, 2005). We envision that the watery, hyperconcentrated flows in outburst floods crossing the Tok fan probably had properties closer to the water-flood end member of the series rather than the debrisflow end member (table 4). In water floods, flow rates are proportional to applied stresses, as they are in other Newtonian fluids (fig. 24). With increasing content of silt and sand, viscosity increases and water flows develop shear strength that must be overcome before flow can occur, entering the realm of non-Newtonian fluids. In the case of Bingham plastic fluids, subsequent deformation is proportional to applied stress (fig. 24). Laboratory studies indicate that sediment concentrations in hyperconcentrated flows range from 20 to 47 volume percent (40 to 70 weight percent), and that these flows apparently behave as both Newtonian and non-Newtonian fluids, depending on the amount of fine fraction present. With increasing content of fine material, the bulk densities of fluids increase, and fall velocities of particles decrease, considerably increasing the amount of material being transported as suspended loads. These particles are uniformly to nonuniformly distributed in the flows and move along turbulent and laminar paths, supported by forces exerted by buoyancy, dispersive stresses between colliding particles, and turbulence (table 4).

Deposits of hyperconcentrated flows range widely in grain size but, because considerable sand is carried in suspension, tend to be matrixsupported gravels and pebbly sands. Typically, these deposits have weak horizontal to massive bedding, and grading in beds is normal to reversed (Costa, 1988). Imbrication is generally weakly developed. 
Figure 23. Diagram showing abundances of gravel, sand, and fine-fraction components in samples of gravel and sand beds in south and west walls of M.S. 62-2-005-2 (table 3, appendix), northeastern Tok fan, Tanacross B-4 Quadrangle (sheet 4 , locality $A$ ).

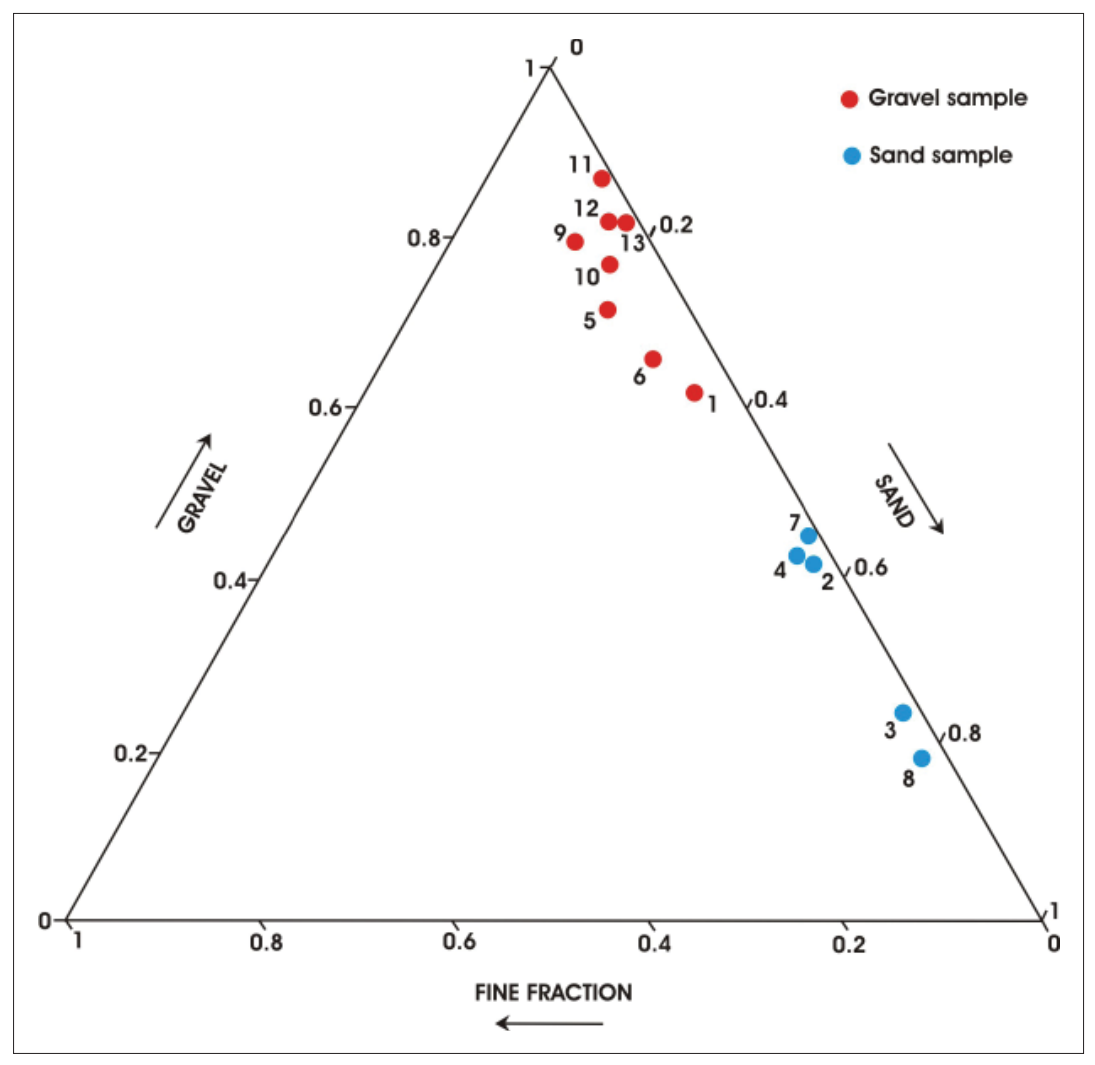

Physiographic evidence indicates that subsequent flooding scoured the Station Creek valley, cutting a 1.1-kmwide channel through the northwestern Mineral Lake moraine of Donnelly age (fig. 22). The resulting outburst floods coursed down the valley of the Little Tok River and deposited a broad gravel expansion fan at the junction with the Tok River valley, where remnants of this former fan are preserved. Floodwaters that began their journey from glacial Lake Atna with low sediment content soon bulked up by entraining coarse and fine material from the Mineral Lake moraine and alluvium in the lower valley of the Little Tok River and in the Tok River valley.

These massive floods must have occurred many times to deliver the huge volume of coarse deposits present in the Tok fan. Inspections of several deep gravel pits indicate that at least the upper $10.6 \mathrm{~m}$ of fan sediments accumulated without a significant hiatus during the Donnelly glaciation. Deeper sediments in the Tok fan were likely laid down by pre-Donnelly outburst floods.

\section{YOUNGER TOK FAN}

The eastern, younger part of the Tok fan is inset into coarse granular deposits of the older fan. The fan surface is covered with meandering and anastomosing former channels that are visible through a thin cover of loess (sheets 3 and 4). Surface morphology indicates that the fan shape was produced by sudden shifts of the Tok River meander belt (avulsion) during periodic floods (Allen, 1965). Thus, the younger fan was built by the normal activities of the Tok River, not by extraordinary outburst floods. Much of the younger fan surface is abandoned floodplain (Qab) that is subject to periodic flooding and is poorly drained. Treads of low terraces ( $\mathrm{Qft}$ ) between active, inactive, and abandoned floodplains are capped by roughly $13 \mathrm{~cm}$ of loess above a layer of fine-grained overbank alluvium that overlies sandy pebble bedload gravel (SP-12) (sheet 4 and fig. 25). Channel fills of sand and sandy pebble gravels display the only significant cross bedding observed on the Tok fan (fig. 26).

Foster (1970) assigned the younger part of the Tok fan to the Donnelly glaciation, and Carrara (2006) dated it as late Pleistocene and Holocene. A sample of grass and bark from a depth of $3 \mathrm{~m}$ in overbank sands in an abandoned channel of the Tok River dates 2,540 \pm 40 RC yr B.P. (Beta-252318) (table 1 and sheet 4, RC-8), demonstrating that the younger part of the Tok fan is Holocene. 


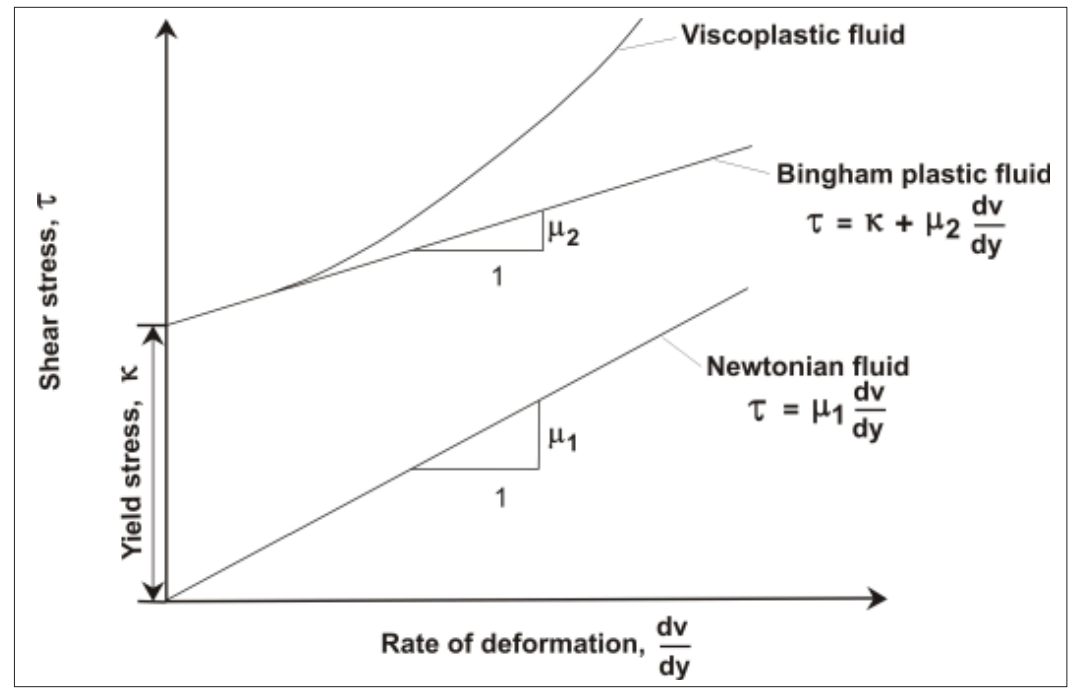

Figure 24. Diagram showing relation of stress to strain in Newtonian and non-Newtonian fluids (after O'Brien and Julien, 1985, fig. 2). Symbols: $\mu$ $=$ dynamic viscosity (slope of curve); $v=$ flow velocity; $y=$ flow depth.

Table 4. Comparison of properties and deposits of water floods, hyperconcentrated flows, and debris flows (after Costa, 1988).

\begin{tabular}{|c|c|c|c|}
\hline Flow Class & Water floods & $\begin{array}{c}\text { Hyperconcentrated } \\
\text { flows }\end{array}$ & Debris flows \\
\hline $\begin{array}{l}\text { Sediment } \\
\text { concentration }^{\mathrm{a}}\end{array}$ & $\begin{array}{c}1-40 \text { wt } \% \\
0.4-20 \text { vol \% }\end{array}$ & $\begin{array}{l}40-70 \text { wt } \% \\
20-47 \text { vol } \% \\
\end{array}$ & $\begin{array}{l}70-90 \text { wt } \% \\
47-77 \text { vol \% } \\
\end{array}$ \\
\hline Bulk density $\left(\mathrm{gm} / \mathrm{cm}^{3}\right)$ & $1.01-1.33$ & $1.33-1.80$ & $1.80-2.30$ \\
\hline $\begin{array}{l}\text { Shear strength } \\
\left(\text { dyne } / \mathrm{cm}^{2}\right)\end{array}$ & $0-100$ & $100-400$ & $>400$ \\
\hline Fluid type (fig. 24) & Newtonian & $\begin{array}{l}\text { Newtonian and } \\
\text { non-Newtonian }\end{array}$ & Viscoplastic \\
\hline $\begin{array}{l}\text { Main sediment } \\
\text { support mechanisms }\end{array}$ & $\begin{array}{l}\text { Electrostatic forces, } \\
\text { turbulence }\end{array}$ & $\begin{array}{l}\text { Buoyancy, dispersive stresses, } \\
\text { turbulence }\end{array}$ & $\begin{array}{l}\text { Cohesion, buoyancy, } \\
\text { dispersive stresses, } \\
\text { structural support }\end{array}$ \\
\hline Viscosity (poise) & $0.01-20$ & $20-\geq 200$ & $>>200$ \\
\hline $\begin{array}{l}\text { Fall velocity (\% of } \\
\text { clear water rate) }\end{array}$ & $100-33$ & $33-0$ & 0 \\
\hline $\begin{array}{l}\text { Sediment } \\
\text { concentration profile }\end{array}$ & Nonuniform & Nonuniform to uniform & Uniform \\
\hline Dominant flow type & Turbulent & $\begin{array}{l}\text { Moderately turbulent to } \\
\text { laminar }\end{array}$ & Laminar \\
\hline $\begin{array}{l}\text { Sediment } \\
\text { characteristics }\end{array}$ & $\begin{array}{l}\text { Wide range of particle sizes; } \\
\text { moderate to poor sorting; } \\
\text { subangular to rounded } \\
\text { clasts; matrix- to clast- } \\
\text { supported sediments }\end{array}$ & $\begin{array}{l}\text { Wide range of grain sizes, but } \\
\text { dominantly medium to coarse } \\
\text { sand; poor sorting; matrix- } \\
\text { supported sediments }\end{array}$ & $\begin{array}{l}\text { Extreme range of particle } \\
\text { sizes, including megaclasts; } \\
\text { negatively skewed; very } \\
\text { poor sorting; matrix- } \\
\text { supported diamictons }\end{array}$ \\
\hline $\begin{array}{l}\text { Sedimentary } \\
\text { Structures }\end{array}$ & $\begin{array}{l}\text { Horizontal to inclined, thin } \\
\text { to massive bedding; } \\
\text { ungraded to graded; weak to } \\
\text { strong imbrication; cut-and- } \\
\text { fill features }\end{array}$ & $\begin{array}{l}\text { Weak horizontal to massive } \\
\text { bedding; normal and reversed } \\
\text { grading; thin gravel lenses; } \\
\text { weak imbrication }\end{array}$ & $\begin{array}{l}\text { Massive bedding; normal } \\
\text { grading near top; inverse } \\
\text { grading at base; weak to no } \\
\text { imbrication }\end{array}$ \\
\hline $\begin{array}{l}\text { Landforms and } \\
\text { deposits }\end{array}$ & $\begin{array}{l}\text { Bars, fans, sheets, splays; } \\
\text { channels have large } \\
\text { width:depth ratios }\end{array}$ & $\begin{array}{l}\text { Similar to water floods but not } \\
\text { well understood }\end{array}$ & $\begin{array}{l}\text { Marginal levees; terminal } \\
\text { lobes; trapezoidal to } \\
\text { U-shaped channels }\end{array}$ \\
\hline
\end{tabular}

\footnotetext{
${ }^{\mathrm{a}}$ Assumes $<10$ vol \% silt and clay.
} 


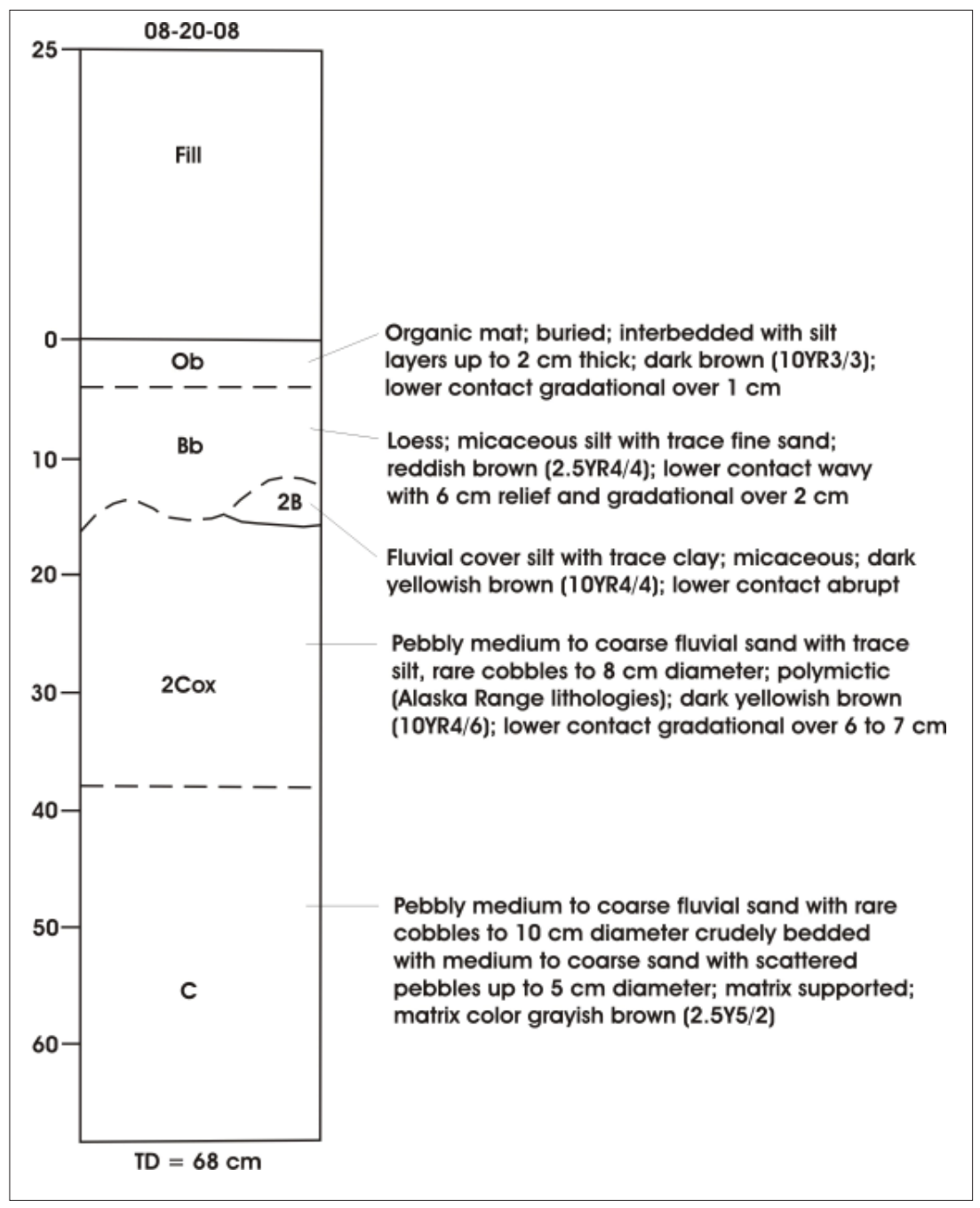

Figure 25. Section (SP-12) exposed in gravel pit in younger part of Tokfan in southwestern Tanacross B-4 Quadrangle. Elevation $\sim 1,660 \mathrm{ft}(\sim 506 \mathrm{~m})$.

\section{TANANA RIVER FLOOD FEATURES}

The earliest known flooding of the Tanana River may be documented beneath the Tetlin Junction dune field by poorly laminated silty clays and sands, which Carrara (2006) interpreted to be of lacustrine origin and dated at 41,880 $\pm 470 \mathrm{RC}$ yr ago (sheet 2 and table 4, RC-5). These fine-grained sediments may have been deposited in a slackwater basin during floods before the last major glaciation.

Small fossil shells of freshwater snails in terrace sands 5 to $6 \mathrm{~m}$ above the Tanana River between the mouth of Porcupine Creek and the crossing of the Tanana River by the Alaska Highway bridge date 11,715 $\pm 40 \mathrm{RC} \mathrm{yr}$ B.P. (table 1 and sheet 4, RC-9), close to the end of the last major glaciation. These sands are another candidate for slackwater-basin deposition because freshwater snails are not known from the very turbid Tanana River. This date provides a maximum age for the floodplain deposits above which the terrace stands.

The expansion fans blocking slackwater basins and impounding lakes north of the meander belt (sheet 3, fig. 2) were deposited by the Tanana River during extraordinary, large-magnitude Holocene floods. Potential sources of Holocene floods that may have produced these deposits are the Tok River valley and the upper Tanana River, including such tributaries as the Nabesna River.

Fragments of willow wood from a black woody peat in abandoned-floodplain deposits between the mouth of Porcupine Creek and the Tanana River bridge east of Tok date 1,610 \pm 40 RC yr B.P. (table 1 and sheet 4, RC-10), confirming the Holocene age of the Tanana River floodplain as determined far downriver by Mason and Begét (1991) and Mann and others (1995).

We found no flood deposits on the 21-m-high bedrock bluffs north of the Tanana River crossing by the Alaska Highway. A cut along the proposed new route of the Alaska Highway (sheet 4, SP-13) displayed up to $95 \mathrm{~cm}$ of 


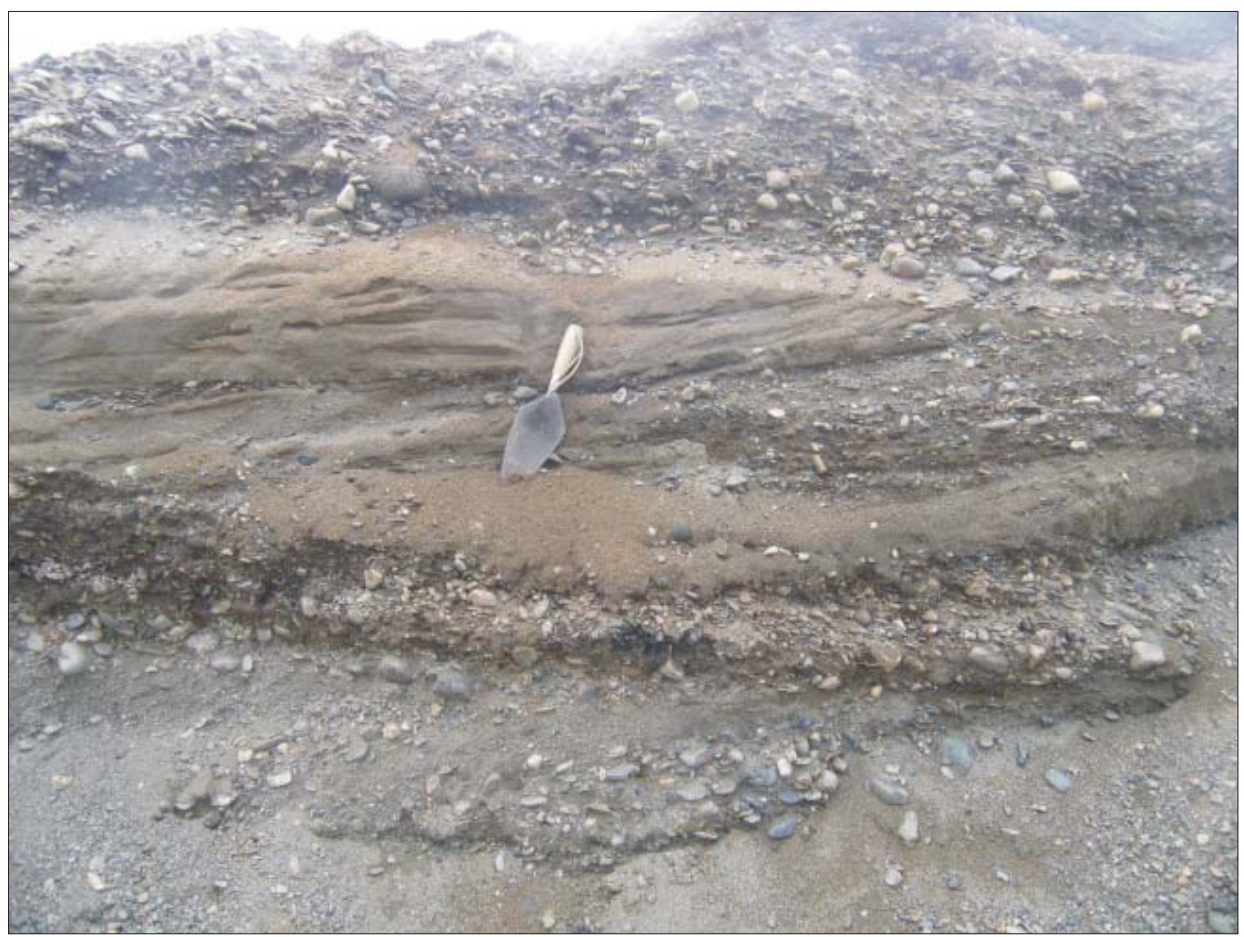

Figure 26. Photo showing cross-bedded sand and sandy pebble-gravel fill in a shallow channel on the younger Tok fan east of the Tok River, central Tanacross B-4 Quadrangle. Massive sandy pebble gravels beneath the channel fill are bedload deposits of the meandering stream that built the fan. Trowel provides scale. Photograph taken 08/19/2008 by T.D. Hubbard.

loess blanketing $\sim 150 \mathrm{~cm}$ of dark grayish brown (2.5Y4/2) very-fine to fine eolian sand with trace silt (fig. 27). The upper 63 to $80 \mathrm{~cm}$ of eolian sand are laced with white calcareous veinlets up to $2 \mathrm{~mm}$ thick as a result of soil formation in the overlying loess. Beneath the eolian sand at depths of $\sim 120$ to $175 \mathrm{~cm}$ is grüssified granitic bedrock with thicker calcareous veinlets.

Several north-northwest-trending airborne resistivity sections across the Tanana River lowland upstream from the eastern edge of the Tok River fan to the eastern limit of corridor segment 2 (sheet 4) indicate that the extensive wetland there is underlain dominantly by moderately conductive clastic alluvium containing considerable groundwater, similar to the section at the Tanana River bridge at the northwestern corner of that lowland (fig. 3) ${ }^{10}$. These sediments are apparently only sporadically frozen. Discontinuous to continuous permafrost is limited to abandoned floodplains and older stream terraces, and to retransported eolian sediments in fans and aprons along the southern margin of the Yukon-Tanana Upland.

\section{MODERN GEOLOGIC HAZARDS}

Mapping and paleoseismic evaluations continue to document evidence of several late Pleistocene and Holocene surface-faulting events (Carver and others, 2010). Strands of the active Cathedral Rapids fault extend from the drainage of Sheep Creek eastward across the lower slopes of the eastern Alaska Range to the vicinity of Moon Lake (sheet 2). This important fault offsets moraines and outwash fans of Delta and Donnelly ages. The genetic relation between the Cathedral Rapids fault and large growth anticlines along the base of the piedmont apron southwest of Tanacross Airfield (sheet 3 ) is now recognized, and evaluations of stream terraces and trench sections indicate that the growth anticlines are tectonically active (Carver and others, 2010). The Cathedral Rapids fault is a potential surface-fault hazard and could generate strong shaking in the corridor (Carver and others, 2008a and b). Violent shaking from this source is likely to destabilize steep terrain and cause widespread liquefaction, particularly in susceptible sediments in the floodplain of the Tanana River (Harp and others, 2003; Hubbard and Reger, 2010).

${ }^{10}$ EM1DFM inversion sections 13640, 13700, 13732, and 13760 (Burns and others, 2006). 
An area of particular concern is the pinch point $\sim 3.7 \mathrm{~km}$ southeast of Moon Lake, where the steep mountain front is only about $1.6 \mathrm{~km}$ south of the Tanana River (sheet 3) and choices are limited for route selection. The Cathedral Rapids fault passes through that area and a local landslide complex shows evidence of recent activity, perhaps in response to fault activity. About $3.2 \mathrm{~km}$ to the east, further challenges to infrastructure are presented near the western edge of the Tok fan by an extensive zone of groundwater emergence (Qfbe), which straddles the Alaska Highway (sheet 3, fig. 28). Other zones of groundwater emergence (Qfbe, Qfte) are mapped along the margin of the Tok fan north-northwest of Tok and east of the Tok River (sheets 3 and 4).

Short, steep streams draining the northern flank of the Alaska Range are subject to torrential floods during periods of heavy precipitation and have built colluvial-fluvial fans (sheet 2) (Grahek and Livingston, 1983). Torrential floods were particularly active in the Cathedral Rapids area following three days of heavy rain near the end of Spring breakup in May 1997 (Chris Bentele, 12/05/2008 oral communication). In some drainages, past torrential flooding deposited natural levees up to $1.8 \mathrm{~m}$ high and $7 \mathrm{~m}$ wide that have overridden and pushed over mature birch

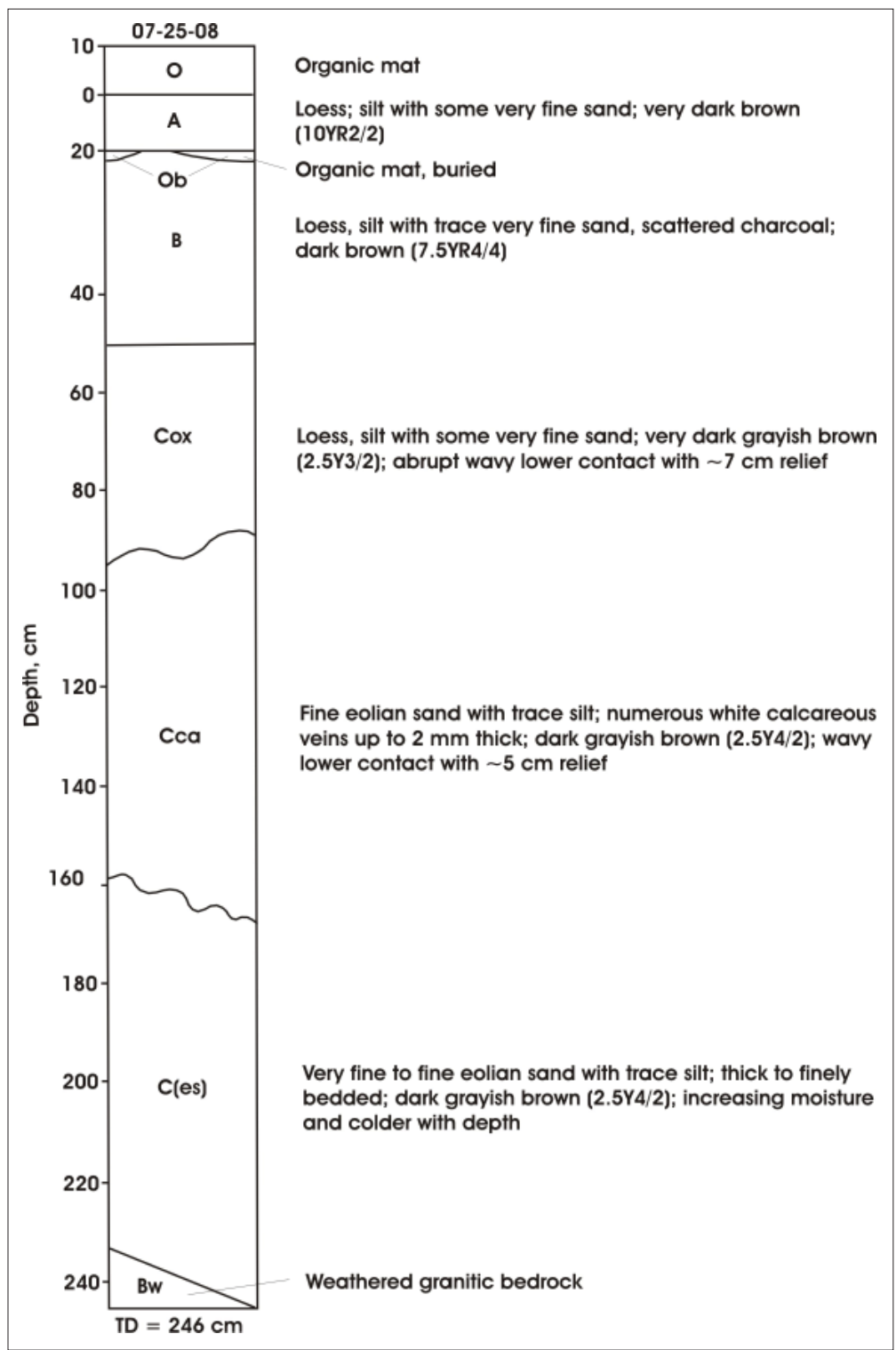

Figure 27. Stratigraphic section (SP-13) in loess and eolian sand blanket over grüssified granitic bedrock on north bank of Tanana River at centerline of proposed new Alaska Highway bridge, southeastern Tanacross B-4 Quadrangle. 
and spruce trees up to $0.3 \mathrm{~m}$ diameter on both sides of stream channels. An alder shrub displaying a curved stem in response to tilting by the emplacement of a natural levee in an unnamed drainage south of Moon Lake (fig. 29) was sectioned, and a count of growth rings in reaction wood (Scurfield, 1973) confirms that the torrential-flood event occurred in 1997. The floodplain of Yerrick Creek is littered with angular to rounded boulders up to $1.6 \mathrm{~m}$ in diameter and is bordered by coarse natural or artificial levees up to $1.8 \mathrm{~m}$ high and more than $4 \mathrm{~m}$ wide (fig. 30). Former concrete bridge abutments and large chunks of reinforced concrete scattered across the floodplain downstream from the present bridge are remnants of the former highway bridge that was destroyed by torrential flooding.

Widespread, shallow, and locally ice-rich permafrost is present in abandoned floodplains and low terraces of the Tanana and Tok rivers and in valleys in the southern Yukon-Tanana Upland (Reger and Hubbard, 2010). Perennially frozen ground is discontinuous beneath inactive floodplains and in moraines, outwash fans, and colluvial-fluvial fans along the north flank of the Alaska Range (Grahek and Livingston, 1983).

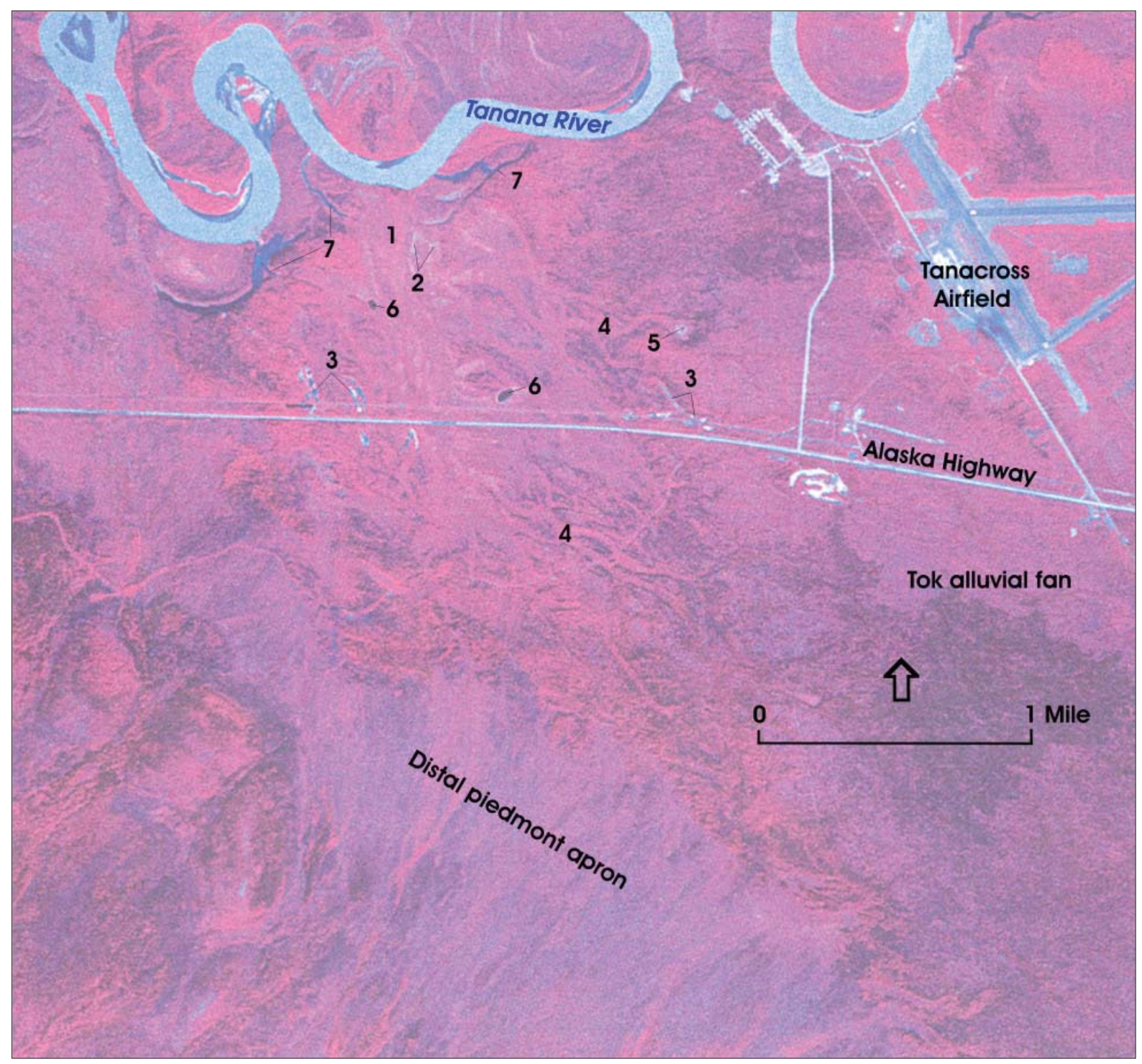

Figure 28. Airphoto showing features indicating groundwater emergence in vicinity of Tanacross Airfield, west-central Tanacross B-5 Quadrangle. Symbols: $1=$ swampy vegetation, $2=$ peat bogs, $3=$ shallow artificial trenches, $4=$ networks of shallow natural drainage channels, $5=$ large clearwater spring, $6=$ small clearwater lakes, and $7=$ clearwater spring discharges (Alaska High Altitude Photograph ALK 60 CIR 21-269 taken July 1978). 


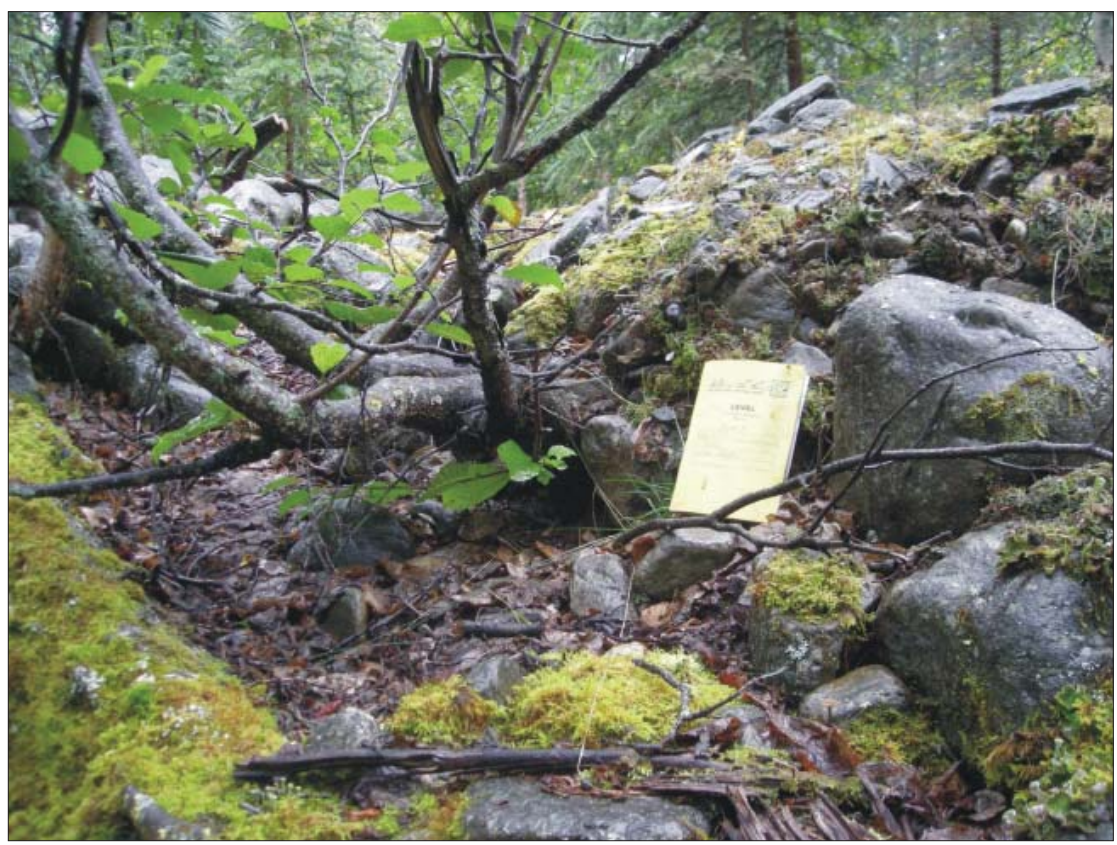

Figure 29. Photo showing curved stems of alder shrub tipped and broken during deposition of natural levee along unnamed small stream above Alaska Highway in east-central Tanacross B-6 Quadrangle. Field notebook measures 11.4 by $17.8 \mathrm{~cm}$. Photograph taken 09/15/2008 by R.D. Reger.

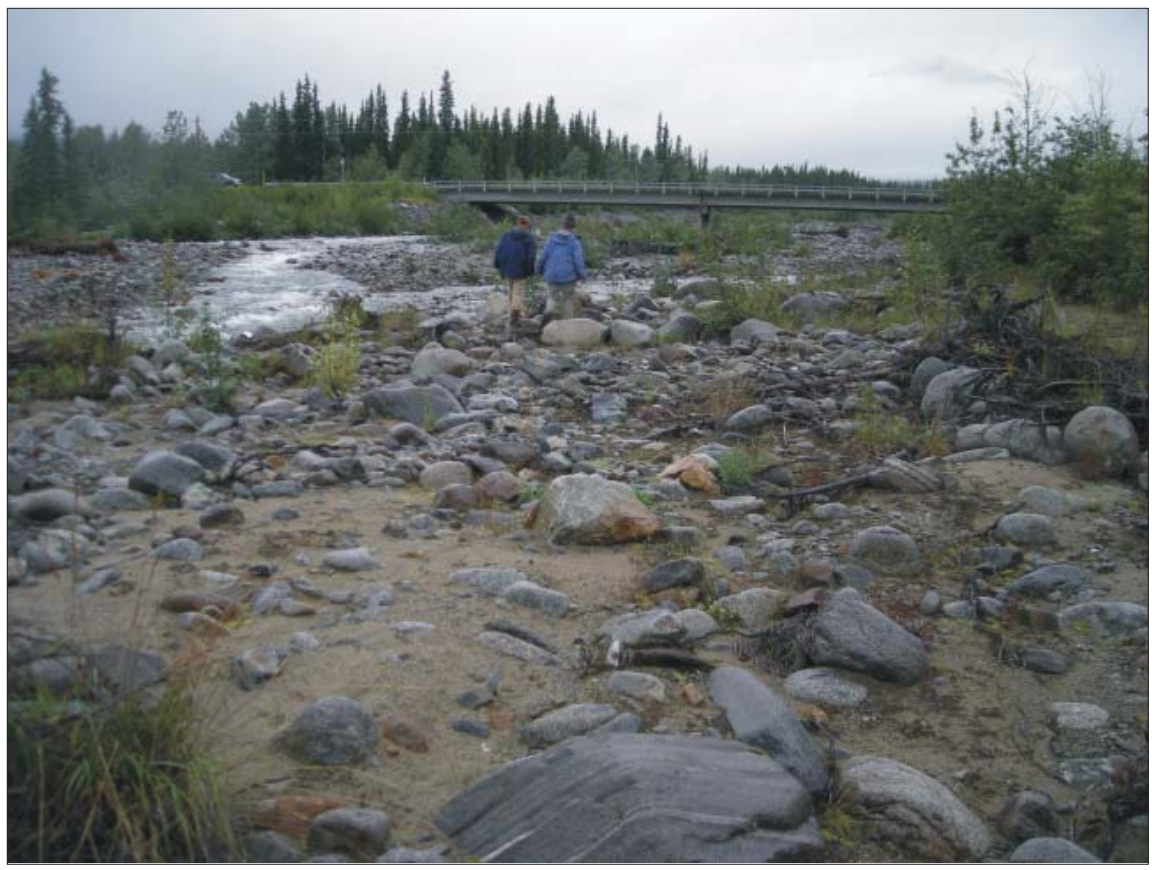

Figure 30. Photo showing view up floodplain of Yerrick Creek toward Alaska Highway bridge, east-central Tanacross B-6 Quadrangle, showing numerous large boulders deposited by torrential flooding. Note reduced summer flow of Yerrick Creek. Persons provide scale. Photograph taken 07/31/2008 by R.D. Reger. 


\section{ACKNOWLEDGMENTS}

Several colleagues in the field and in Fairbanks provided assistance, samples, photographs, and stimulating discussions, including (in alphabetical order) Joe Andrew, Sean Bemis, Sammy Castonguay, Rod Combellick, Larry Freeman, Sharon Hansen, Kyle Obermiller, Joyce Outten, Santosh Panda, Anupma Prakash, Rinu Samuel, Diana Solie, De Anne Stevens, Rhea Supplee, and Melanie Werdon. Each flying day we greatly appreciated the skill and dedication of pilot Tom Ratledge, who delayed several evening suppers to bring us safely back to camp. Friendly hospitality, excellent meals, and comfortable camp facilities were provided by Chris Bentele, owner of Cathedral Creeks B \& B, and her husband, Dave Thorp. Glenn and John Burnham of Burnham Construction Inc. in Tok freely shared their considerable experience and observations of surficial geology in the Tok area and provided copies of local water-well logs. Discussions of Quaternary glaciations and past environments in the Tok area and information provided by our USGS colleagues Paul Carrara and Tom Ager have been especially helpful. We also enjoyed sharing intriguing insights on neotectonism of the Alaska Highway corridor with Sean Bemis. We thank De Anne Stevens for creating the location map of the second corridor segment. The Fairbanks office of Shannon and Wilson Inc. conducted the seive analyses of gravel and sand samples from M.S. 62-2-005-2. Diana Solie and De Anne Stevens kindly agreed to review this document and offered several very helpful suggestions that helped to clarify this report. Funding for this project was provided by the State of Alaska.

\section{REFERENCES}

Allen, J.R.L., 1965, A review of the origin and characteristics of recent alluvial sediments: Sedimentology, v. 5, no. 2, p. 89-191.

Bemis, S.P., and Wallace, W.K., 2007, Neotectonic framework of the north-central Alaska Range foothills, in Ridgeway, K.D., Trop, J.M., Glen, J.M.G., and O’Neill, J.M., eds., Tectonic growth of a collisional continental margin - Crustal evolution of southern Alaska: Geological Society of America Special Paper 431, p. 549-572.

Blair, T.C., and McPherson, J.G., 1994, Alluvial fans and their natural distinction from rivers based on morphology, hydraulic processes, sedimentary processes, and facies assemblages: Journal of Sedimentary Research, v. A64, no. 3, p. 450-489.

Burns, L.E., Fugro Airborne Surveys Corp., and Stevens Exploration Management Corp., 2006, Line, grid, and vector data, and plot files for the airborne geophysical survey of the Alaska Highway corridor, east-central Alaska: Alaska Division of Geological \& Geophysical Surveys Geophysical Report 2006-6, 1 DVD.

Carlson, L.J., and Finney, B.P., 2004, A 13,000-year history of vegetation and environmental change at Jan Lake, east-central Alaska: The Holocene, v. 14, no. 6, p. 818-827.

Carrara, P.E., 2004a, Surficial geologic map of the Tanacross B-6 Quadrangle, east-central Alaska: U.S. Geological Survey Scientific Investigations Map 2850, version 1.0, 9 p., 1 plate, scale 1:63,360.

2004b, Surficial geologic map of the Tanacross B-5 Quadrangle, east-central Alaska: U.S. Geological Survey Scientific Investigations Map 2856, version 1.0, 9 p., 1 plate, scale 1:63,360.

2006, Surficial geologic map of the Tanacross B-4 Q Quadrangle, east-central Alaska: U.S. Geological Survey Scientific Investigations Map 2935, version 1.0, 1 plate, scale 1:63,360.

Carter, L.D., and Galloway, J.P., 1978, Preliminary engineering geologic maps of the proposed natural gas pipeline route in the Tanana River valley, Alaska: U.S. Geological Survey Open-file Report 78-794, 26 p., 3 plates, scale $1: 125,000$.

Carver, G.A., Bemis, S.P., Solie, D.N., and Obermiller, K.E., 2008a, Active and potentially active faults in or near the Alaska Highway corridor, Delta Junction to Dot Lake: Alaska Division of Geological \& Geophysical Surveys Preliminary Interpretive Report 2008-3d, 32 p.

Carver, G.A., Bemis, S.P., Solie, D.N., Obermiller, K.E., and Weldon, R., 2008b, Active faults in or near the proposed trans-Alaska gas pipeline corridor, east-central Alaska [abs.]: Seismological Research Letters, v. 79, no. 2, p. 360.

Carver, G.A., Bemis, S.P., Solie, D.N., Castonguay, S., and Obermiller, K.E., 2010, Active and potentially active faults in or near the Alaska Highway corridor, Robertson River to Tetlin Junction: Alaska Division of Geological \& Geophysical Surveys Preliminary Interpretive Report 2010-1, 42 p.

Clarke, A.H., 1981, The freshwater mollusks of Canada: Ottawa, National Museums of Canada, 446 p.

Combellick, R.A., 2006, Building a natural gas pipeline through earthquake country: Geotimes, v. 51, no. 11, p. $18-22$.

Cossart, E., Braucher, R., Fort, M., Bourlés, D.L., and Carcaillet, J., 2008, Slope instability in relation to glacial debuttressing in alpine areas (Upper Durance catchment, southeastern France)—Evidence from field data and ${ }^{10} \mathrm{Be}$ cosmic ray exposure ages: Geomorphology, v. 95, p. 3-26 (doi:10.1016/j.geomorph.2006.12.022). 
Costa, J.E., 1988, Rheologic, geomorphic, and sedimentologic differentiation of water floods, hyperconcentrated flows, and debris flows, in Baker, V.R., Kochel, R.C., and Patton, P.C., eds., Flood geomorphology: New York, John Wiley \& Sons, p. 113-122.

Duk-Rodkin, A., Barendregt, R.W., Froese, D.G., Weber, F., Enkin, R., Smith, I.R., Waters, P., and Klassen, R., 2004, Timing and extent of Plio-Pleistocene glaciations in northwestern Canada and east-central Alaska, in Ehlers, J., and Gibbard, P.L., eds., Quaternary glaciations — extent and chronology, part II—North America: New York, Elsevier, Development in Quaternary Science, v. 2, p. 313-345.

Duk-Rodkin, A., Weber, F., and Barendregt, R.W., 2002, Glacial limits of upper Yukon River: Geological Survey of Canada Open-file 4275, 1 plate, scale 1:1,000,000.

Fernald, A.T., 1965a, Glaciation in the Nabesna River area, upper Tanana River valley, Alaska, in U.S. Geological Survey Research 1965: U.S. Geological Survey Professional Paper 525-C, p. C120-C123.

1965b, Recent history of the upper Tanana River lowland, Alaska, in U.S. Geological Survey Research 1965: U.S. Geological Survey Professional Paper 525-C, p. C124-C127.

Fitch, G., 2008, Foundation geology report, Tanana River Bridge \#505, Project no. BR-OA2-1(8): Alaska Department of Transportation and Public Facilities report, $415 \mathrm{p}$.

Foster, H.L., 1970, Reconnaissance geologic map of the Tanacross Quadrangle, Alaska: U.S. Geological Survey Miscellaneous Geologic Investigations Map I-593, 1 plate, scale 1:250,000.

Foster, H.L., and Keith, T.E.C., 1969, Geology along the Taylor Highway, Alaska: U.S. Geological Survey Bulletin $1281,36 \mathrm{p}$.

Grahek, M.E., and Livingston, H.R., 1983, Centerline soils and materials sources, Mile Post 1346.7 to 1332.8 , Alaska Highway, Robertson River to Yerrick Creek, Project No. F-062-2(14): Alaska Department of Transportation and Public Facilities Engineering Geology \& Soils report, 121 p.

Harp, E.L., Jibson, R.W., Kayen, R.E., Keefer, D.K., Sherrod, B.L., Carver, G.A., Collins, B.D., Moss, R.E.S., and Sitar, N., 2003, Landslides and liquefaction triggered by the M7.9 Denali Fault earthquake of 3 November 2002: GSA Today, v. 13, no. 8, p. 4-10.

Holmes, G.W., 1965, Geologic reconnaissance along the Alaska Highway, Delta River to Tok Junction, Alaska: U.S. Geological Survey Bulletin 1181-H, 19 p., 1 plate, scale 1:125,000.

Holmes, G.W., Hopkins, D.M., and Foster, H.L., 1968, Pingos in central Alaska: U.S. Geological Survey Bulletin 1241-H, $40 \mathrm{p}$.

Hubbard, T.D., and Reger, R.D., 2010, Engineering geologic map, Alaska Highway corridor, Robertson River to Tetlin Junction, Alaska: Alaska Division of Geological \& Geophysical Surveys Preliminary Interpretive Report 2009-6b, 4 sheets, scale 1:63,360.

Hughes, O.L., 1989, Quaternary chronology, Yukon and western District of Mackenzie, in Carter, L.D., Hamilton, T.D., and Galloway, J.P., eds., Late Cenozoic history of interior basins of Alaska and the Yukon: U.S. Geological Survey Circular 1026, p. 25-29.

Kreig, R.A., and Reger, R.D., 1982, Air-photo analysis and summary of landform soil properties along the route of the Trans-Alaska Pipeline System: Alaska Division of Geological \& Geophysical Surveys Geologic Report $66,149 \mathrm{p}$.

Mann, D.H., Fastie, C.L., Rowland, E.L., and Bigelow, N.H., 1995, Spruce succession, disturbance, and geomorphology on the Tanana River floodplain, Alaska Ecoscience, v. 2, no. 2, p. 184-199.

Matmon, A., Briner, J.P., Carver, G., Bierman, P., and Finkel, R.C., 2010, Moraine chronosequence of the Donnelly Dome region, Alaska: Quaternary Research, v. 74, no. 1, p. 63-72.

Mason, O.K., and Begét, J.E., 1991, Late Holocene flood history of the Tanana River, Alaska, U.S.A.: Arctic and Alpine Research, v. 23, no. 4, p. 392-403.

O'Brien, J.S., and Julien, P.Y., 1985, Physical properties and mechanics of hyperconcentrated sediment flows, in Bowles, D.S., ed., Delineation of landslide, flash-flood, and debris-flow hazards in Utah: Logan, Utah Water Research Laboratory report, p. 260-279.

Péwé, T.L., 1975, Quaternary geology of Alaska: U.S. Geological Survey Professional Paper 835, 145 p.

Pierson, T.C., 2005, Hyperconcentrated flows - transitional process between water flow and debris flow, in Jakob, M., and Hungr, O., eds., Debris-flow hazards and related phenomena: Berlin, Springer, p. 159-202.

Pierson, T.C., and Costa, J.E., 1987, A rheologic classification of subaerial sediment-water flows, in Costa, J.E., and Wieczorek, G.F., eds., Debris flows and avalanches: Geological Society of America Reviews in Engineering Geology, v. VII, p. 1-12.

Reger, R.D., and Hubbard, T.D., 2009, Evidence for late Wisconsinan outburst floods in the Tok-Tanacross basin, upper Tanana River valley, east-central Alaska (abs.): Geological Society of America Abstracts with Programs, v. 41 , no. 7, p. 637. 
2010, Reconnaissance interpretation of 1978 to 1983 permafrost, Alaska Highway corridor, Robertson River to Tetlin Junction, Alaska: Alaska Division of Geological \& Geophysical Surveys Preliminary Interpretive Report 2009-6c, 4 sheets, scale 1:63,360.

Reger, R.D., and Péwé, T.L., 2002, Geologic map of the Big Delta A-4 Quadrangle, Alaska: Alaska Division of Geological \& Geophysical Surveys Report of Investigations 2002-2, 1 sheet, scale 1:63,360.

Reger, R.D., and Solie, D.N., 2008a, Reconnaissance interpretation of permafrost, Alaska Highway corridor, Delta Junction to Dot Lake, Alaska: Alaska Division of Geological \& Geophysical Surveys Preliminary Interpretive Report 2008-3c, 10 p., 2 sheets, scale 1:63,360.

2008b, Engineering geology map, Alaska Highway corridor, Delta Junction to Dot Lake, Alaska: Alaska Division of Geological \& Geophysical Surveys Preliminary Interpretive Report 2008-3b, 2 sheets, scale 1:63,360.

Reger, R.D., Stevens, D.S.P., and Solie, D.N., 2008a, Surficial geology of the Alaska Highway corridor, Big Delta and Mt. Hayes quadrangles, Alaska: Alaska Division of Geological \& Geophysical Surveys Preliminary Interpretive Report 2008-3a, 48 p., 2 sheets, scale 1:63,360.

2008b, Evidence of multiple outburst floods, upper Tanana River valley, eastcentral Alaska [abs.]: Geological Society of America Abstracts with Programs, v. 40, no. 1, p. 36.

Richter, D.H., 1976, Geologic map of the Nabesna Quadrangle, Alaska: U.S. Geological Survey Miscellaneous Investigations Map I-932, 1 plate, scale 1:250,000.

Schaefer, J.R.G., 2002, Stratigraphy, major oxide geochemistry, and ${ }^{40} \mathrm{Ar} /{ }^{39} \mathrm{Ar}$ geochronology of a tephra section near Tok, Alaska: Fairbanks, Alaska, University of Alaska Fairbanks MS thesis, 62 p.

Schmoll, H.R., 1984, Late Pleistocene morainal and glaciolacustrine geology in the upper Copper River-Mentasta Pass area, Alaska [abs.]: Geological Society of America Abstracts with Programs, v. 16, no. 6, p. 330.

Scurfield, G., 1973, Reaction wood-Its structure and function: Science, v. 179, no. 4074, p. 647-655.

Smith, G.A., 1986, Coarse-grained nonmarine volcaniclastic sediment: Terminology and depositional process: Geological Society of America Bulletin, v. 97, no. 1, p. 1-10.

Sneed, E.D., and Folk, R.L., 1958, Pebbles in the lower Colorado River, Texas: A study in particle morphogenesis: Journal of Geology, v. 66, p. 114-150.

Soil Survey Staff, 1975, Soil taxonomy, a basic system of soil classification for making and interpreting soil surveys: Washington, D.C., U.S. Department of Agriculture Soil Conservation Service Agriculture Handbook 436, 754 p.

Solie, D.N., and Burns, L.E., 2006, Geology, geophysics, and geohazards along the Alaska Highway Corridor, Alaska: Alaska Division of Geological \& Geophysical Surveys poster presented at Yukon Geoscience Forum, November 26-20, 2006, Whitehorse, Yukon Territory, Canada.

2007, Alaska Highway corridor geology and geophysics: Alaska GeoSurvey News, v. 10, no. 1, p. 1-4.

Sturm, M., and Benson, C.S., 1989, Jökulhlaups from Strandline Lake, Alaska, with special attention to the 1982 event: Alaska Division of Geological \& Geophysical Surveys Report of Investigations 88-10, 19 p.

Sturm, M., Begét, J.E., and Benson, C.S., 1987, Observations of jökulhlaups from ice-dammed Strandline Lake, Alaska: Implications for paleohydrology, in Mayer, L., and Nash, D., eds., Catastrophic flooding: Boston, Allen and Unwin, p. 79-94.

Tarnocai, C., Smith, S., and Hughes, O.L., 1985, Soil development on Quaternary deposits of various ages in the central Yukon Territory: Geological Survey of Canada Paper 85-1A, Current Research, Part A, p. 229-238.

Thorson, R.M., 1986, Late Cenozoic glaciation of the northern Nenana Valley, in Hamilton, T.D., Reed, K.M., and Thorson, R.M., eds., Glaciation in Alaska, the geologic record: Anchorage, Alaska Geological Society, p. 99-121.

Thorson, R.M., and Bender, Gary, 1985, Eolian deflation by ancient katabatic withds: A late Quaternary example from the north Alaska Range: Geological Society of America Bulletin, v. 96, no. 6, p. 702-709.

Tweed, F.S., and Russell, A.J., 1999, Controls on the formation and sudden drainage of glacier-impounded lakes: Implications for jökulhlaup characteristics: Progress in Physical Geography, v. 23, no. 1, p. 79-110.

Wallace, R.E., 1948, Cave-in lakes in the Nabesna, Chisana, and Tanana River valleys, eastern Alaska: Journal of Geology, v. 56, no. 3, p. 171-181.

Williams, J.R., 1970, Ground water in the permafrost regions of Alaska: U.S. Geological Survey Professional Paper 696, 83 p. 


\section{APPENDIX A}

Shannon \& Wilson, Inc. reports of grain-size analyses of sediment samples S-1 through S-13 from M.S. 62-2-005-2 (sheet 4, locality A), northeastern Tok fan, Tanacross B-4 Quadrangle 



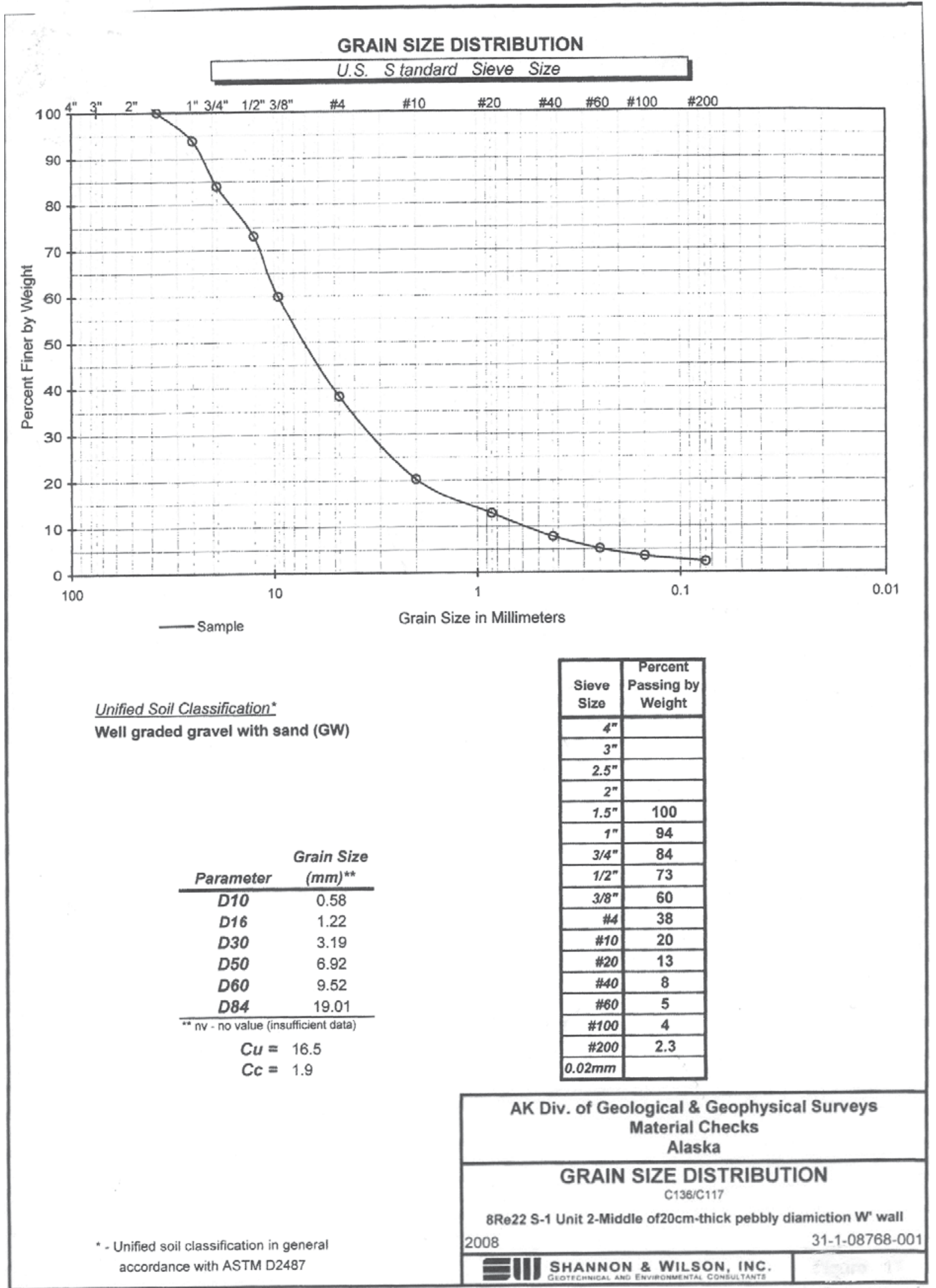

Figure A1. Diagram showing grain-size distribution of sample S-1 from M.S. 62-2-005-2 (fig. 20; sheet 4, locality A). 


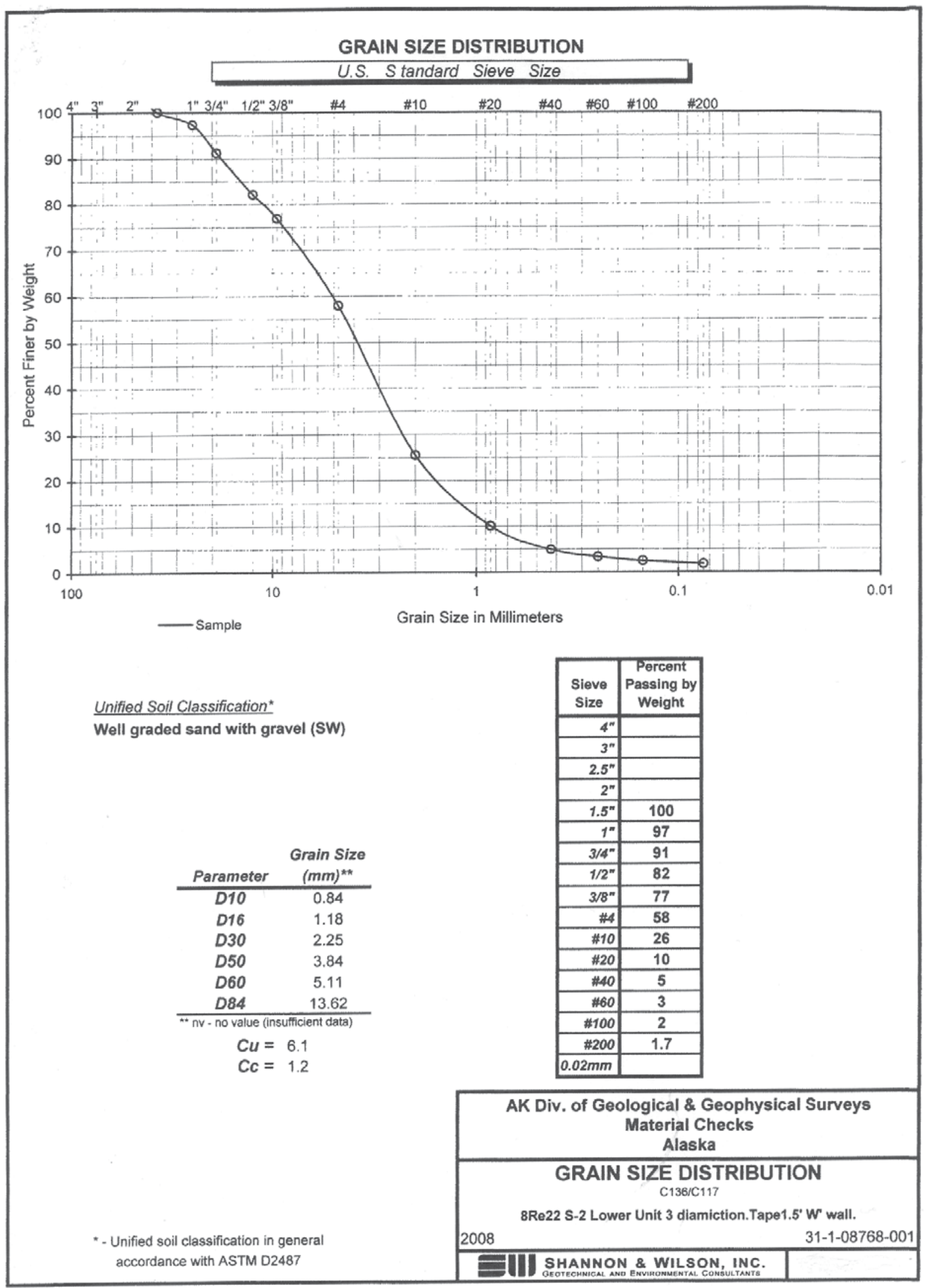

Figure A2. Diagram showing grain-size distribution of sample S-2 from M.S. 62-2-005-2 (fig. 20; sheet 4, locality A). 


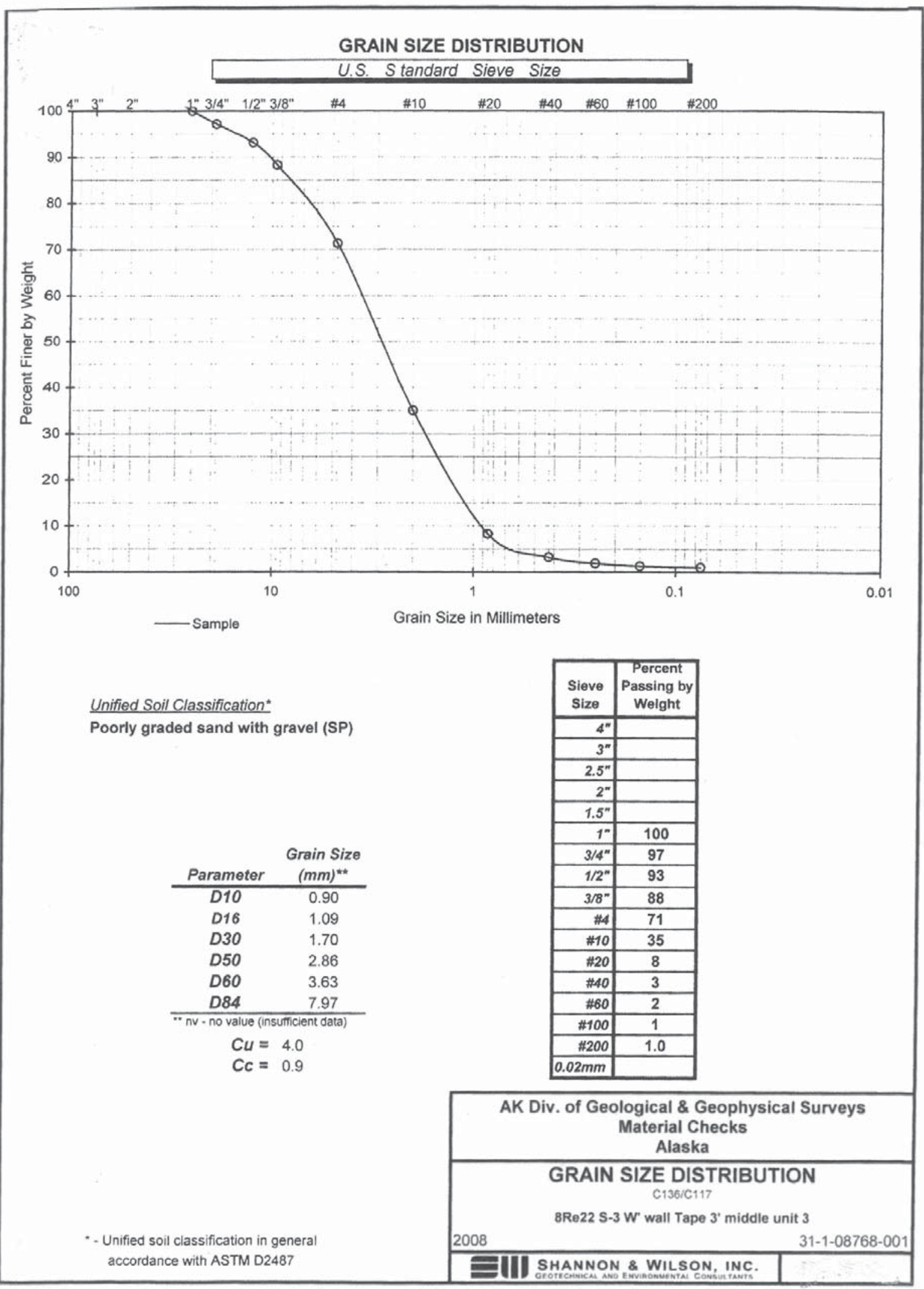

Figure A3. Diagram showing grain-size distribution of sample S-3 from M.S. 62-2-005-2 (fig. 20; sheet 4, locality A). 


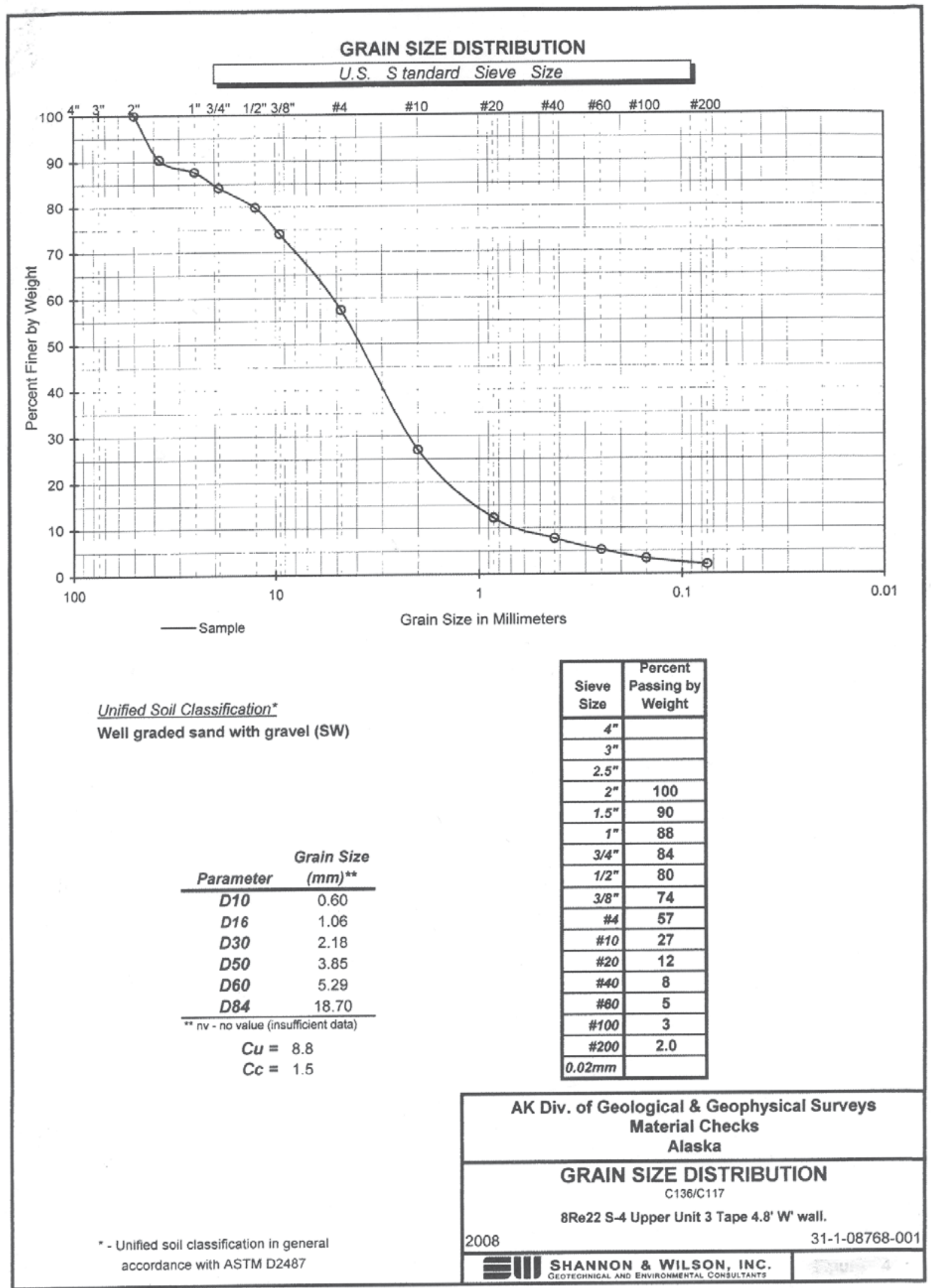

Figure A4. Diagram showing grain-size distribution of sample S-4 from M.S. 62-2-005-2 (fig. 20; sheet 4, locality A). 


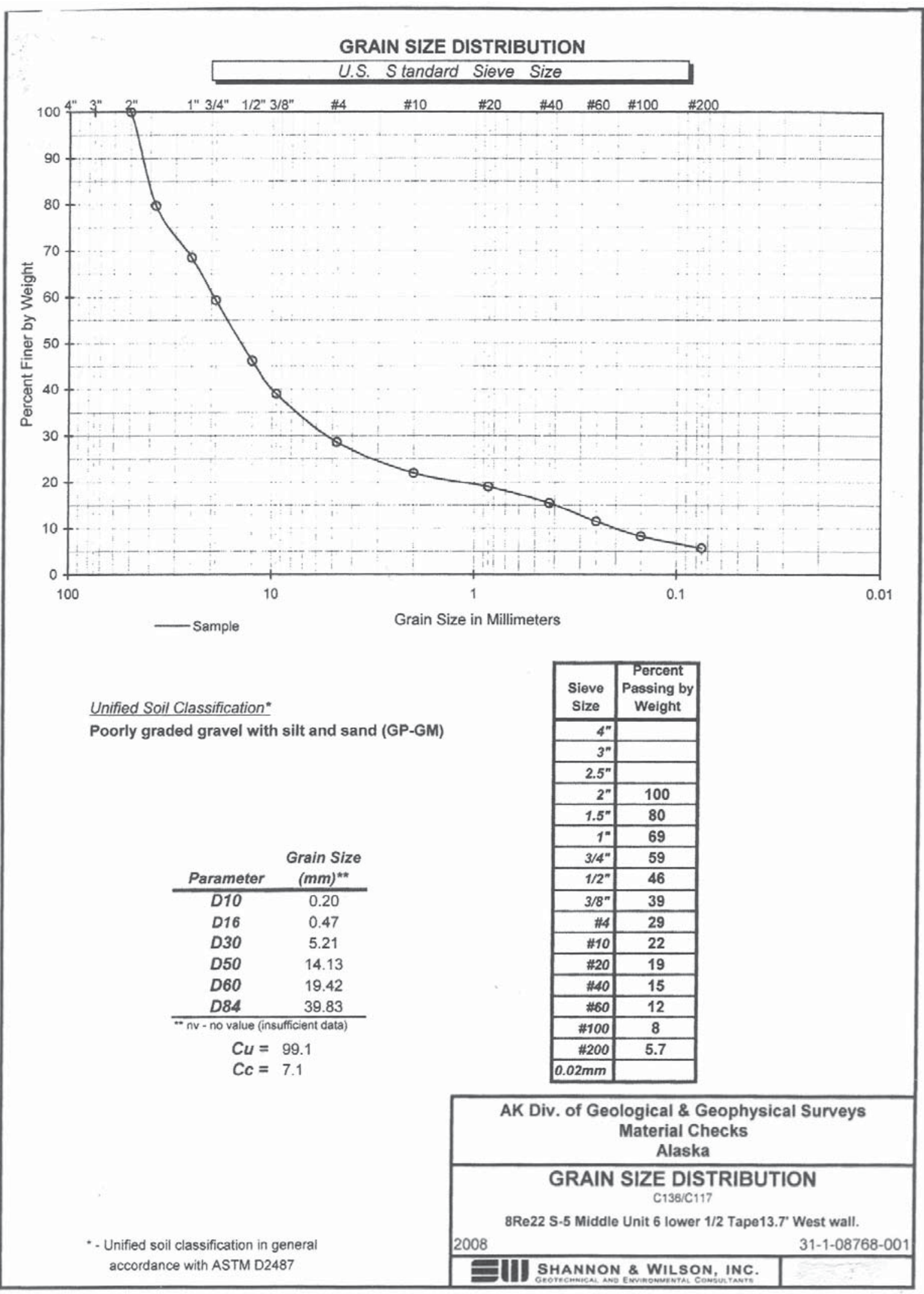

Figure A5. Diagram showing grain-size distribution of sample S-5 from M.S. 62-2-005-2 (fig. 20; sheet 4, locality A). 


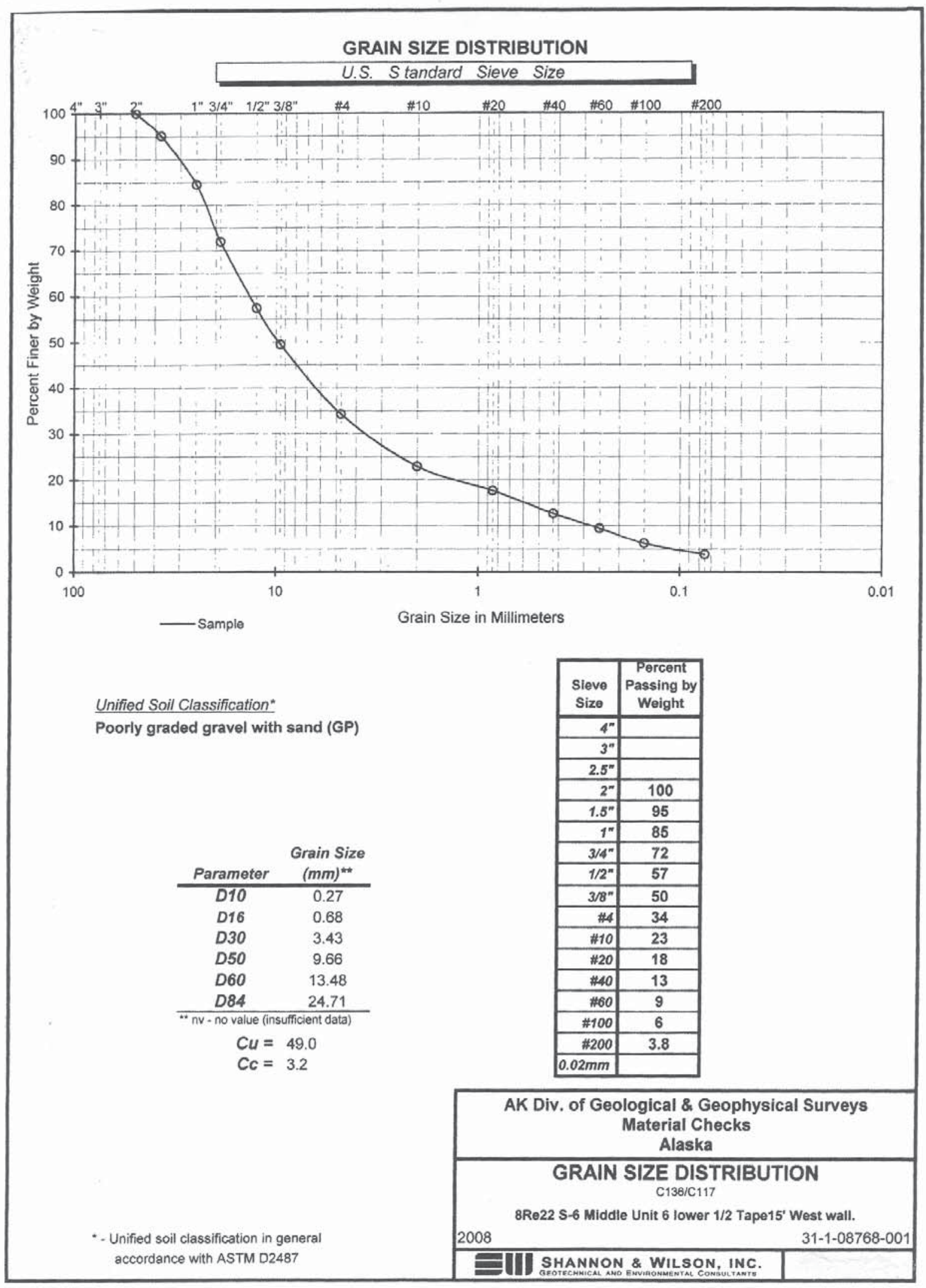

Figure A6. Diagram showing grain-size distribution of sample S-6 from M.S. 62-2-005-2 (fig. 20; sheet 4, locality A). 


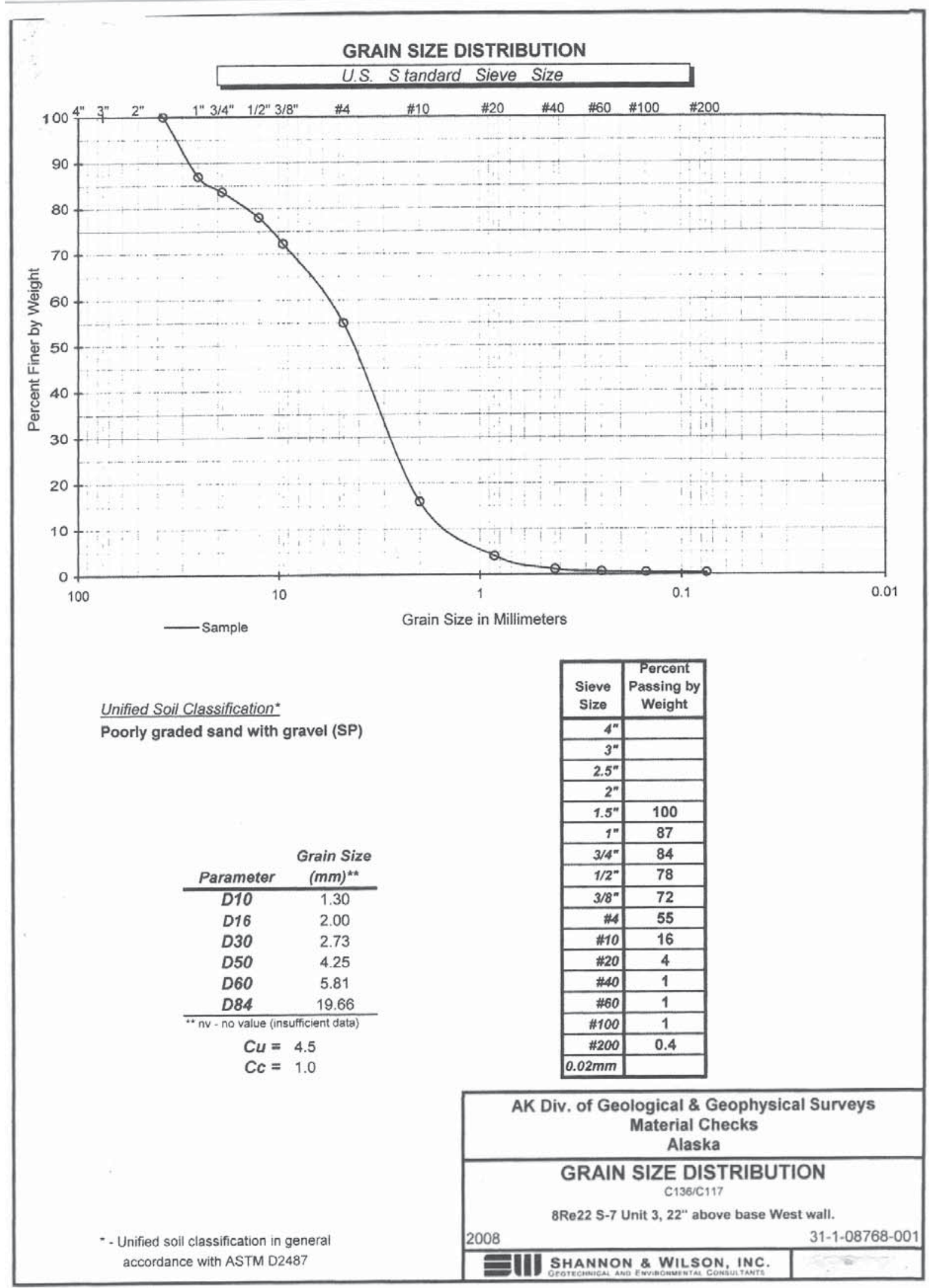

Figure A7. Diagram showing grain-size distribution of sample S-7 from M.S. 62-2-005-2 (fig. 20; sheet 4, locality A). 


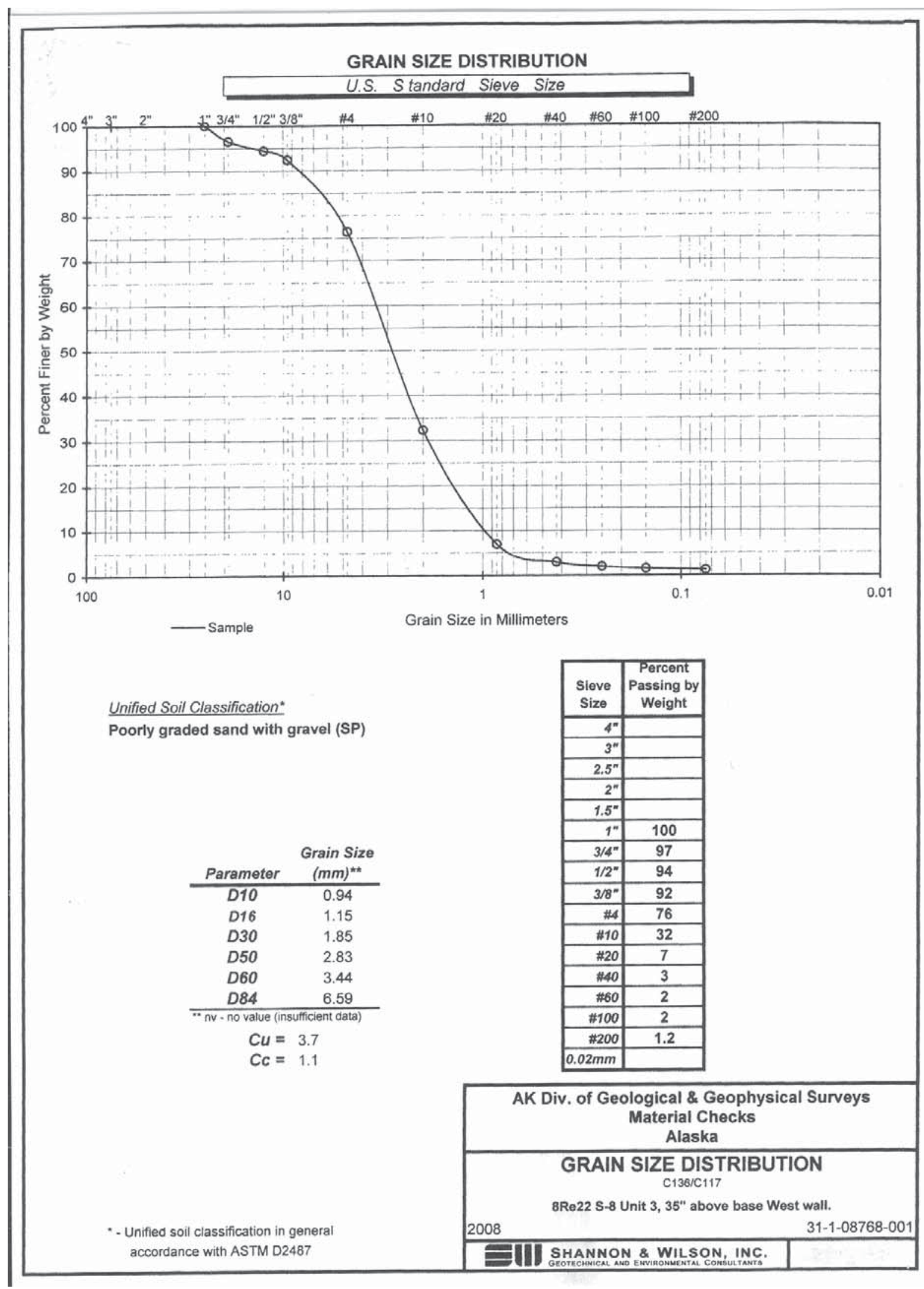

Figure A8. Diagram showing grain-size distribution of sample S-8 from M.S. 62-2-005-2 (fig. 20; sheet 4, locality A). 


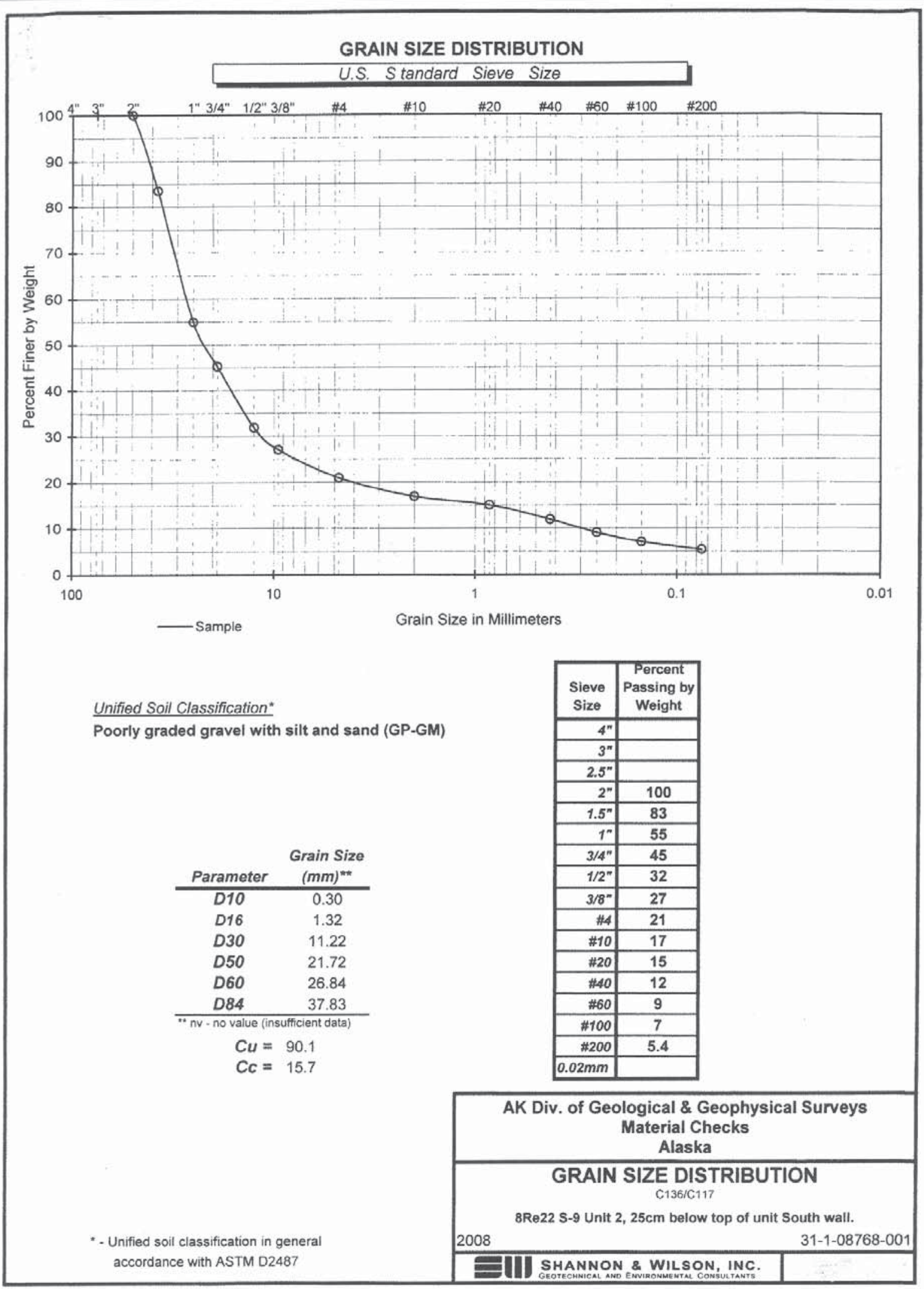

Figure A9. Diagram showing grain-size distribution of sample S-9 from M.S. 62-2-005-2 (fig. 18; sheet 4, locality A). 


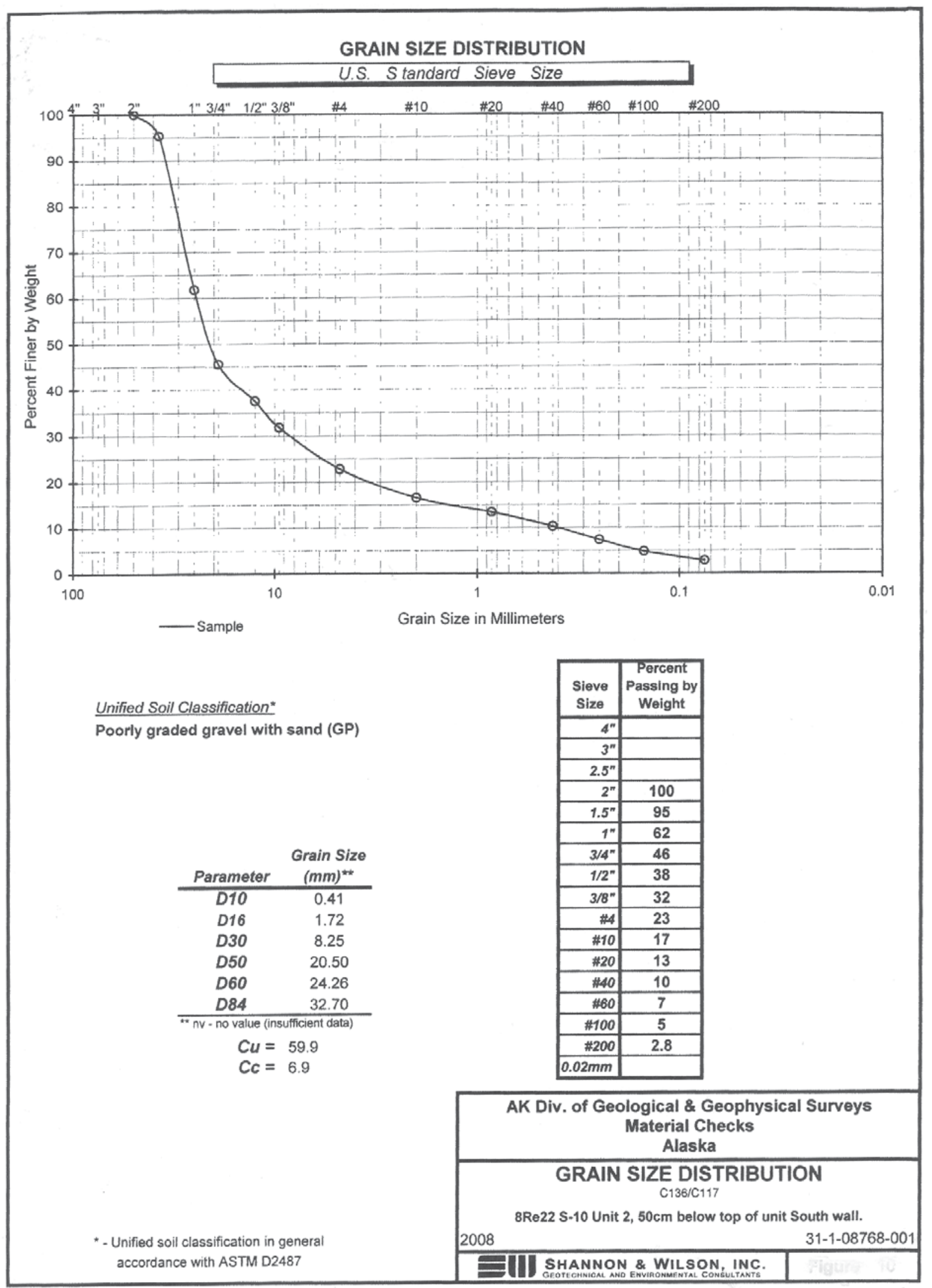

Figure A10. Diagram showing grain-size distribution of sample S-10 from M.S. 62-2-005-2 (fig. 18; sheet 4, locality A). 


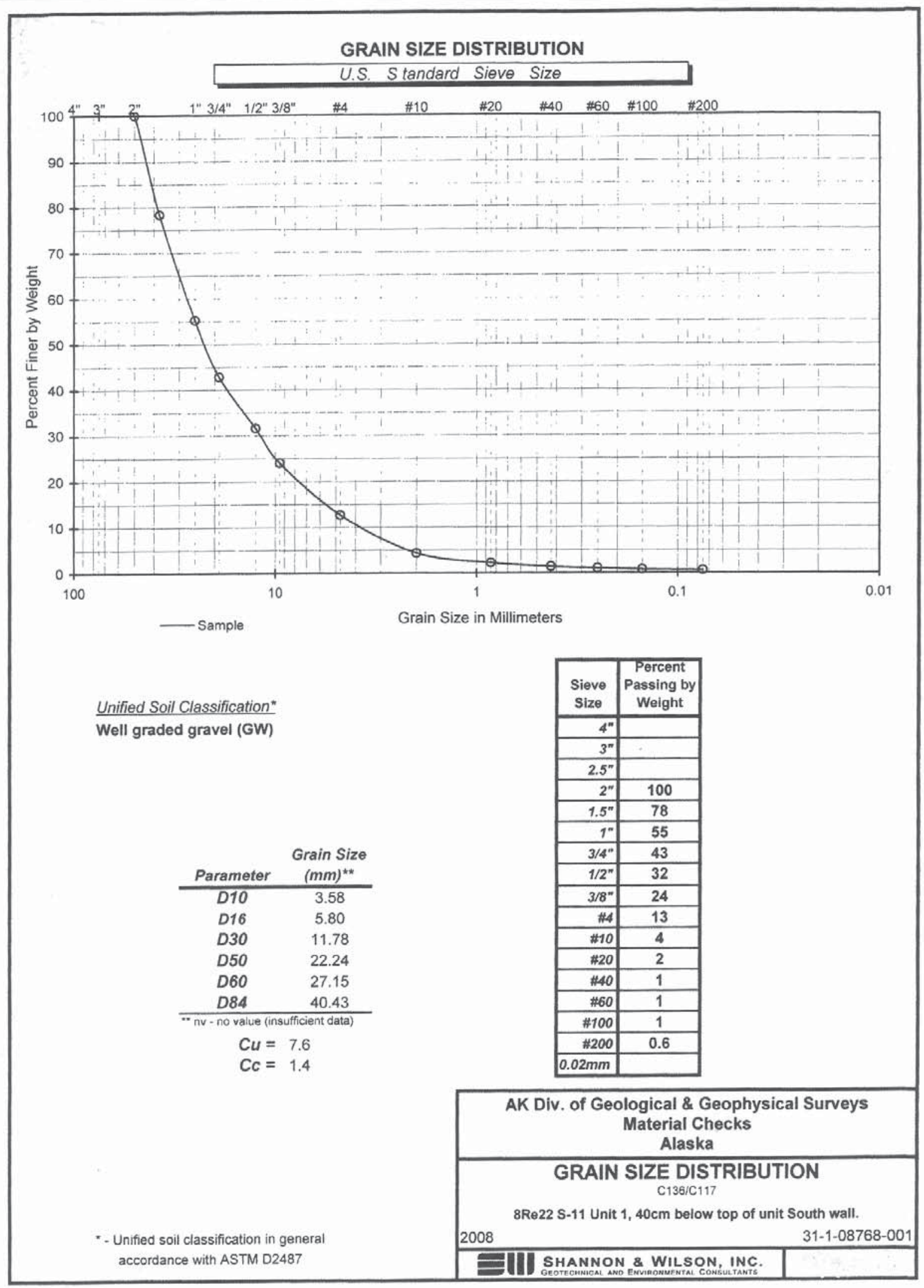

Figure A11 Diagram showing grain-size distribution of sample S-11 from M.S. 62-2-005-2 (fig. 18; sheet 4, locality A). 


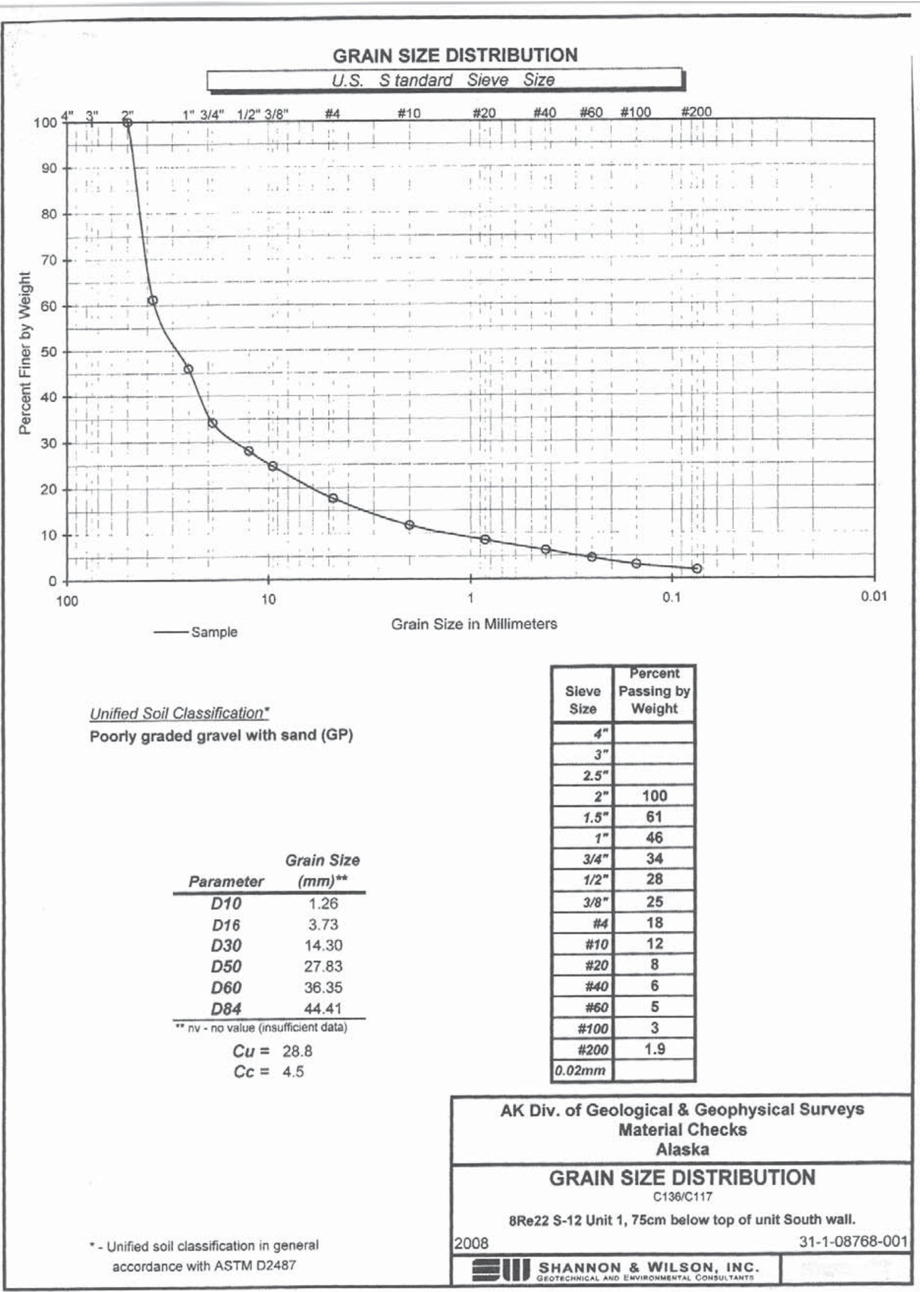

Figure A12. Diagram showing grain-size distribution of sample S-12 from M.S. 62-2-005-2 (fig. 18; sheet 4, locality A). 


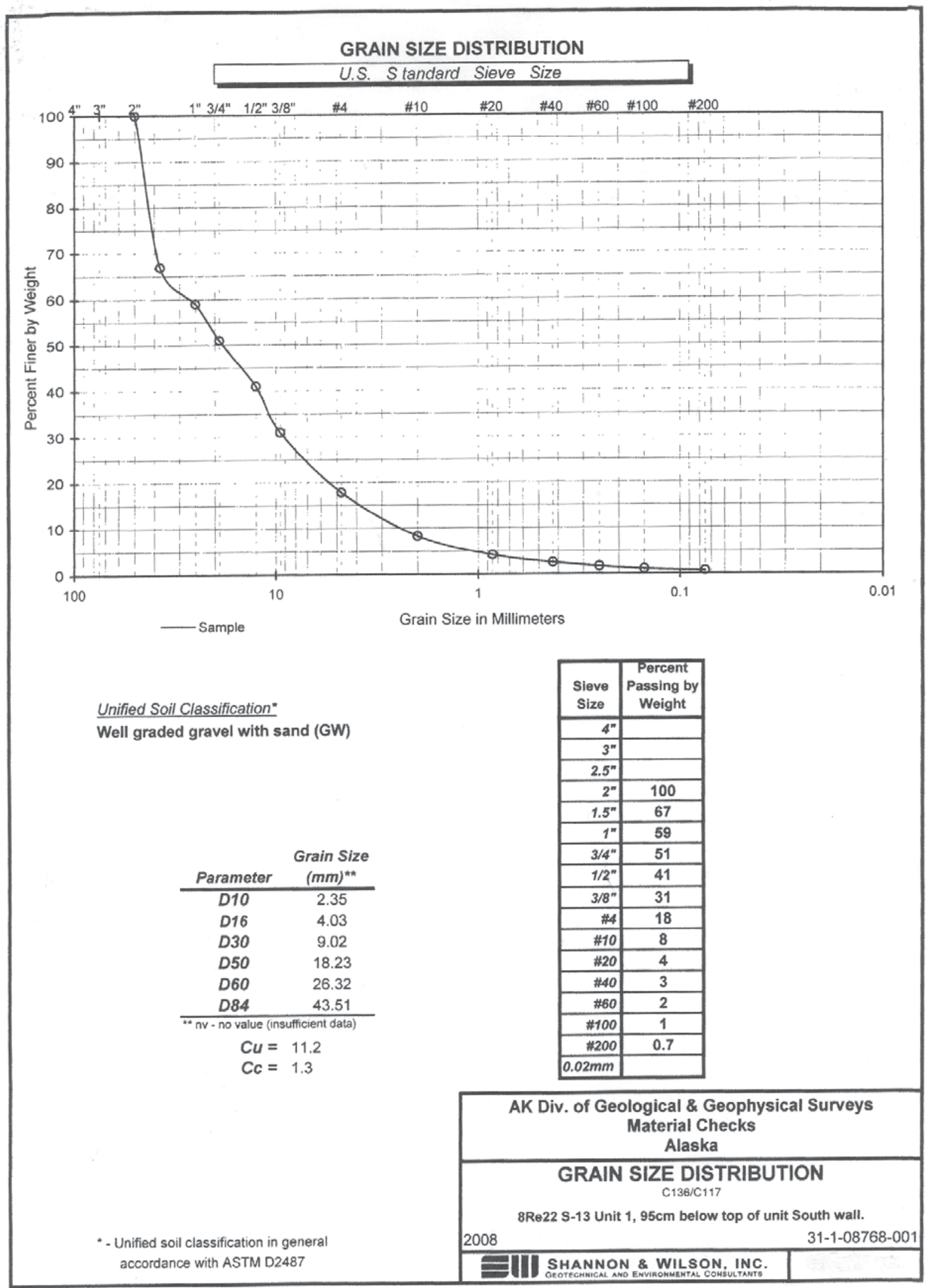

Figure A13. Diagram showing grain-size distribution of sample S-13 from M.S. 62-2-005-2 (fig. 18; sheet 4, locality A). 